STATE OF ILLINOIS

DEPARTMENT OF REGISTRATION AND EDUCATION

DIVISION OF THE

NATURAL HISTORY SURVEY

STEPHEN A. FORBES, Chief

Vol. XVIII.

BULLETIN

Article II.

\title{
Fall and Winter Stoneflies, or Plecoptera, of Illinois
}

BY

THEODORE H. FRISON

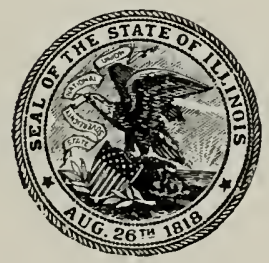

PRINTED BY AUTHORITY OF THE STATE OF ILLINOIS

URBANA, ILLINOIS

May, 1929 


\section{STATE OF ILLINOIS}

\section{DEPARTMENT OF REGISTRATION AND EDUCATION}

A. M. Sheitox, Director

BOARD OF

NATURAL RESOURCES AND CONSERVATION

A. M. SIILLTOx, Chairman

Willis.m Trelease, Biology

Hexir C. Cowles, Forestry

Eusox S. Bastix, Geology

WillaM A. NoYes, Chemistry
JoHN W. Alvord, Engincering

Charles M. Thompsox, Representing the President of the University of Illinois

THE NATURAL HISTORY SURVEY DIVISION

Stephex A. Fonres, Chief

H. C. Oesterting, Editor

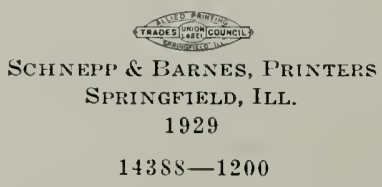




\section{CONTENTS}

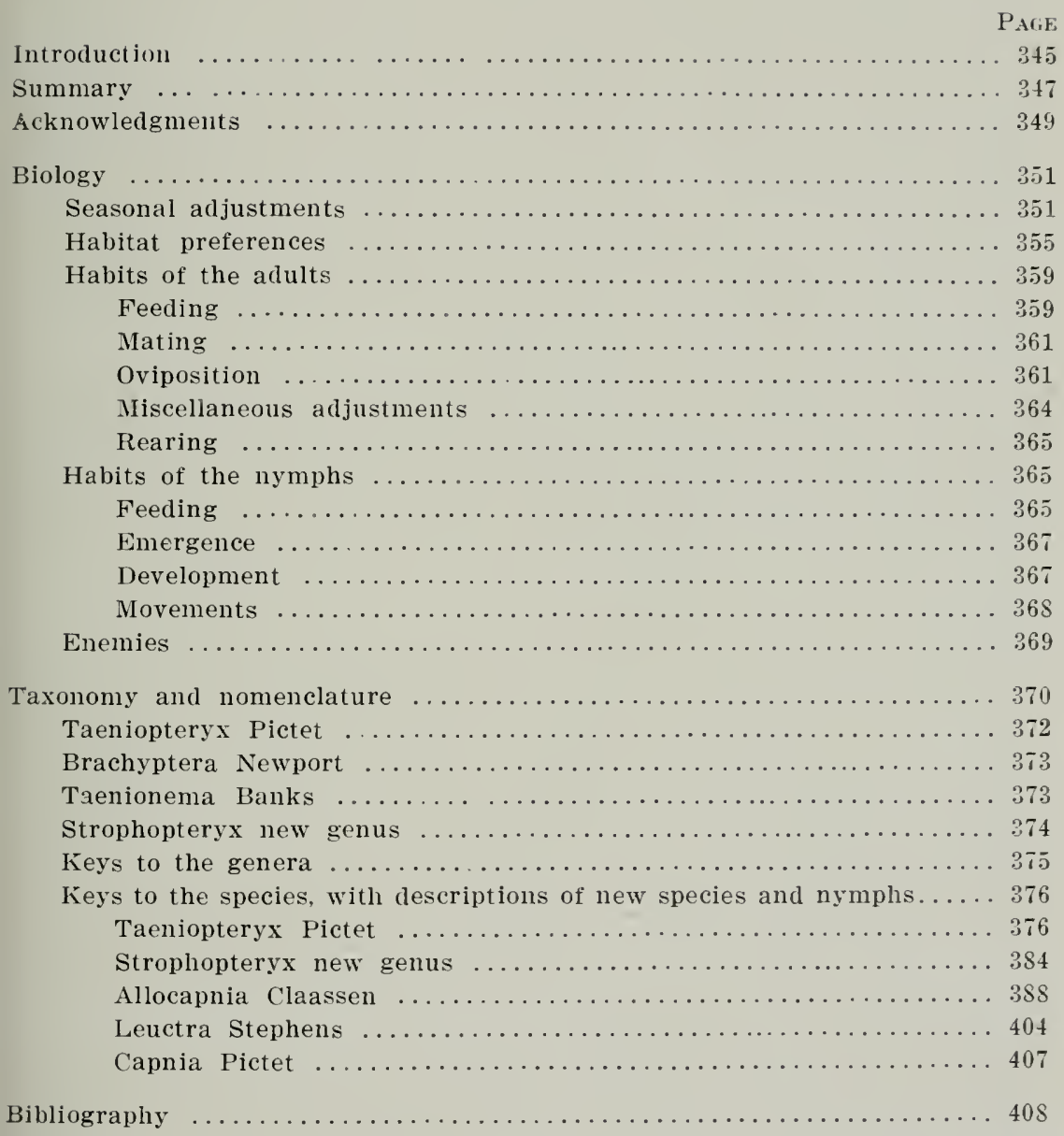




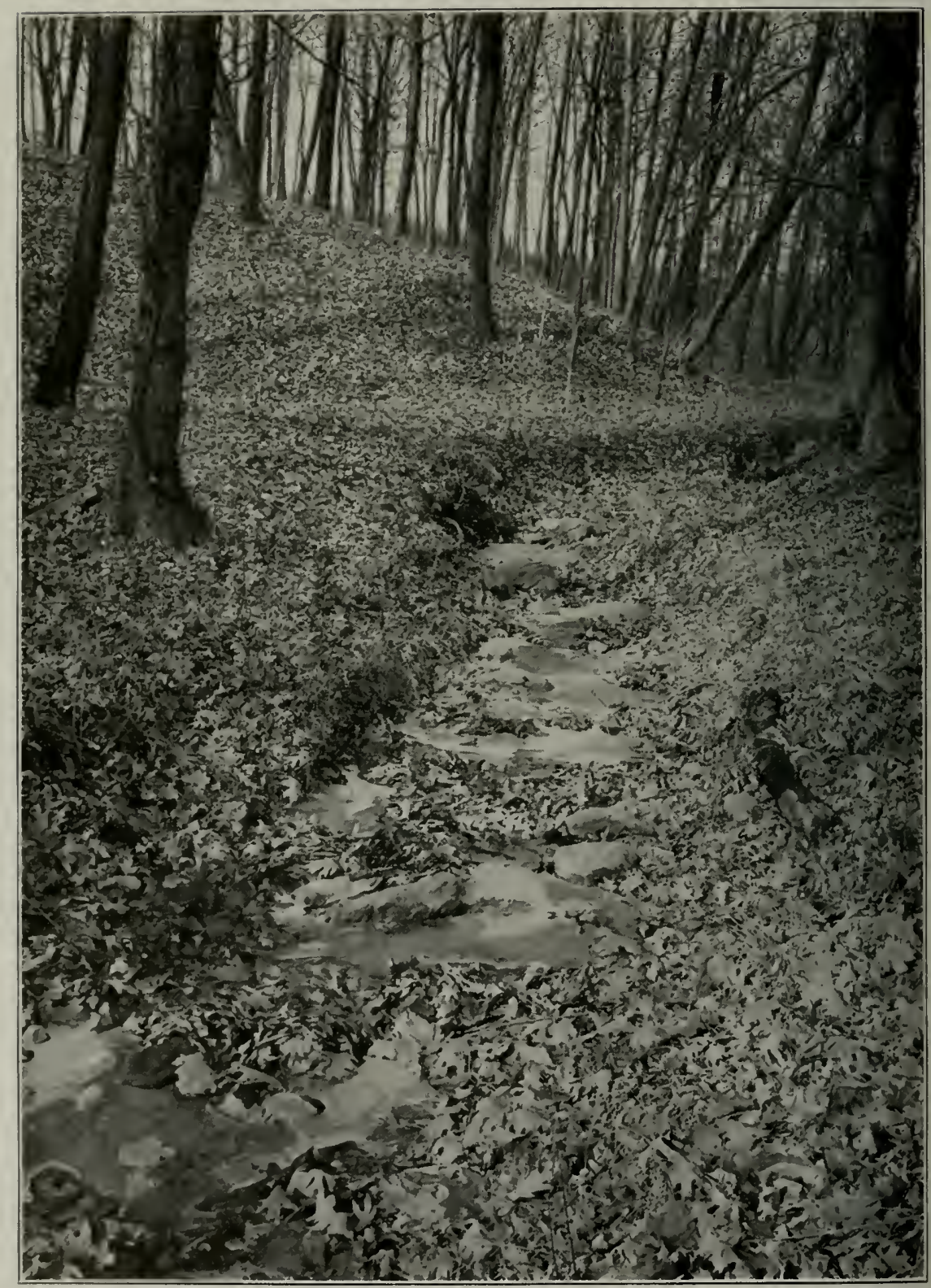

Fig. 1. View of a small brook (Station IV) two miles south of Oakwood, Illinois. Habitat of two species of fall and winter stoneflies, Allocapnia recta (Claassen) and A. vivipara (Claassen). December 27, 1928. 


\title{
FALL AND WINTER S'TONEFLIES, OR PLECOP'TERA, OF ILIINOIS
}

\author{
THEODORE H. Frison
}

The life of the fall and winter stoneflies is a striking exception to the general rule that insect activity ceases with the approach of cold weather. This rule holds true for the vast majority of insects living in temperate climates. particularly for those linds which are conspicuous becatuse of their large size, their bright coloring, or the damage that they do. To certain other insects. however. usually of smaller proportions and duller hues, a chilling temperature is the signal for their greatest activity, their most pronounced growth, and the reproduction of their kind. Many years ago $(1+1 \%)$ Asa Fitch, the first state entomologist of New York, said of them: "They are the objects of curiosity, as coming forth to our view in full maturity and vigor, at that time of year when almost every other member of the animal and vegetable kingdoms is reposing in torpiclity under the chilling influence of solstitial cold." At least ten species of stoneflies in Illinois respond to cold weather in this way. To anyone not well acquainted with our fall and winter fauna, it is a startling revelation to see such large insects spriglitly climbing up tree trunks in search of food when temperatures are near or below freezing, or to watch then crawling over the ice and snow which partly holds in its embrace the waters that nurtured their infancy. Such phenomena cannot fail to excite wonder and forcefully bring to mind the wonderful adaptiveness of the insect world-one of the chief reasons why insects so ont-number all other kinds of animal life.

Even students of the great out-of-doors are for the most part unaware of the numerical abundance and importance of our winter insect fanna. Mthough myself a lover of the woods and fields of central Illinois: for many years and acquainted with them in their varions noods, the active fall and winter insect fauna, particularly the stoneflies, dicl not attract ny attention until November, three winters ago. Then a chance examination of a small but charming brooklet soutl of Oakwood, Illinois, proved a revelation and incited me to make a study of the more salient features of the bionomics and classification of our fall and winter stoneflies. Recourse to the literature of the subject soon revealed that alnost nothing was known concerning the habits of these archaic afuatic insects, so that any data I might secure would be worth recording. 
Because of the richness of the fall and winter stonefly fauna in the vicinity of Oakwood. Which is not far from Urbana, that locality has been visited many times during the progress of the investigation, and it has been the center of most of the biological studies. The variety of specics thriving in its several streams is no doubt due to the diversity of aquatic habitats there, and perliaps also to the relative freedom from pollution that the streams enjoy. The Salt Fork at many places in this part of its course flows over a stony bottom, and many of its small tributarics are rapid brooks of rocky character nestled in forested ravines. One area in particular has been intensively studied in relation to differ-

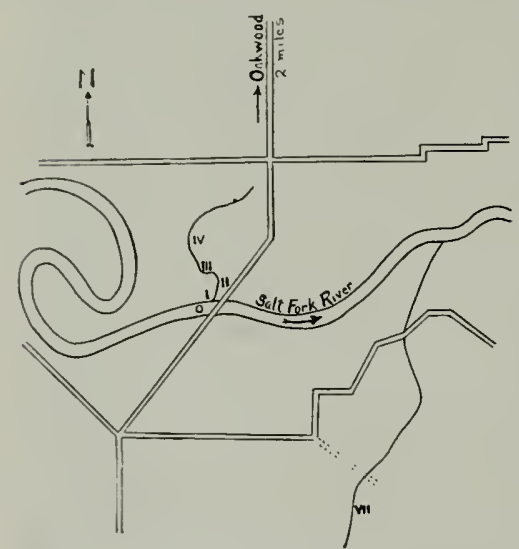

Fig. 2. Sketch map of the Oakwood area, showing stations where extensive collections of stoneflies were made. Scale: 1 inch equals 1 mile. ences in distribution and biology of the different fall and winter stoneflies occurring there, and a sketch map of this area (Figure 2) is presented for convenience in referring to special places by station numbers. (Cf. Figures 1, 4, and 5.)

In order that comparative data might be secured concerning the kinds and distribution of the fall and winter stoneflies throughout Illinois, several collecting trips were made in November. March, and the first week of April to various sections of the state. In the course of these trips, collections were made at approximately fifty different places (Figure 3 ), and the data thus obtained give a good picture of the distribution of these insects in this state.

Because of their habit of congregating in places exposed to the warming influences of the sun's rays, most of the fall and winter stonefly adults have proved easy of capture. During the warmer days of late fall or early winter one is apt to sec some of them energetically crawling about on exposed tree trunks, fence posts, or rocks located close to a stream inhabited by the nymphs, particularly if these objects are covered with an algal growth. The white concrete bridges (Figure $\hat{\imath}$ ) so characteristic of our highways throughout Illinois are very attractive to the adults and afford excellent collecting places. Here the insects are easily seen as they crawl alout in the sum. With an automobile for transportation one can make many collections from diverse localities during a single day. Sometimes a hundred or more adults can be collected on one bridge and a complete census made of the species of the locality cluring a ten or fifteen minute stop. Since the adults as well as the nymphs are best preserved for study in a liquid medium, no special time-consuming tech- 
nique is needed for their preservation; they can be placed directly in vials containing eighty per cent alcohol or a two per cent formalin solution. Pinned specimens shrivel badly and usually must be boiled a short time in potassium hydroxicle before their structural details can be distinguished.

The insect life of our inland streams affords a most interesting and profitable field for investigation; and the sooner we learn to correctly place and evaluate this fauna, the sooner will we be in a position to formulate conclusions and generalizations of importance in our efforts to unclerstand our aquatic resources and intelligently forward their use.

\section{SUMIMARI}

In this paper are presented the results of an investigation of the biological and systematical characteristics of five genera, comprising eleven species, of the little-known fall and winter stoneflies occurring in Illinois. It has been found that these species differ biologically from one another in respect to their seasonal adjustments, the hahitats they prefer, oviposition. and in many other details of their life histories. In opposition to general ideas concerning the food liabits of the orcler as a whole, the adults as well as the nymphs were found to be herbivorous.

Because of a previous erroneous designation of a genotype, it has been necessary to replace the generic name of Ncplicloptcry'. Klapalek with Tacnioptcry.r Pictet (s'nsu str.), revive the name of Brachyptera for another generic complex perhaps endemic to the Palaearctic fauna, substitute Tacnioncuna Banks for a Nearctic conplex, and erect a new Nearctic genus Strophoptery.r. In order to facilitate the determination of the Illinois species, keys for the determination of the adlults and nymphs to genera and spe-

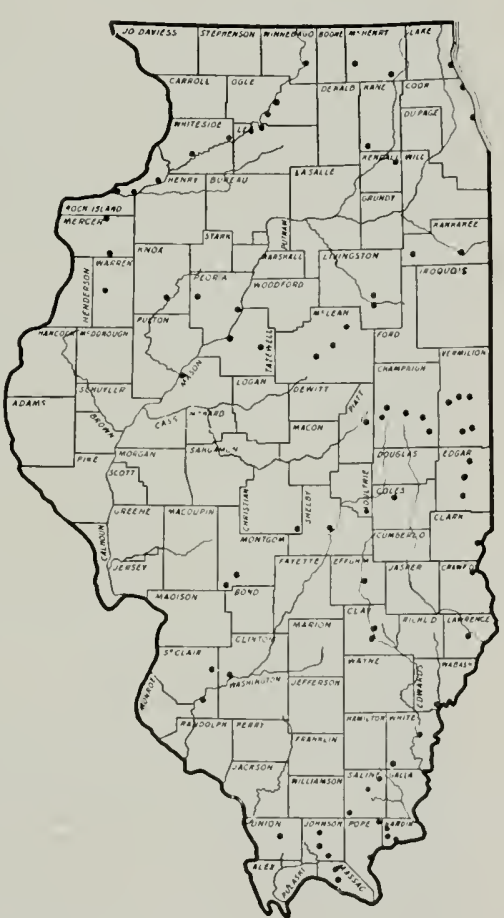

Fig. 3. Sketch map of Illinois, showing localities in which stoneflies were collected. cies have been formulated, critical systematical and distributional information has been presented for each species, and three species new to science have been described (Allocapmia mystica, Allocapnia forbesi, and Lenctra claassoni). 


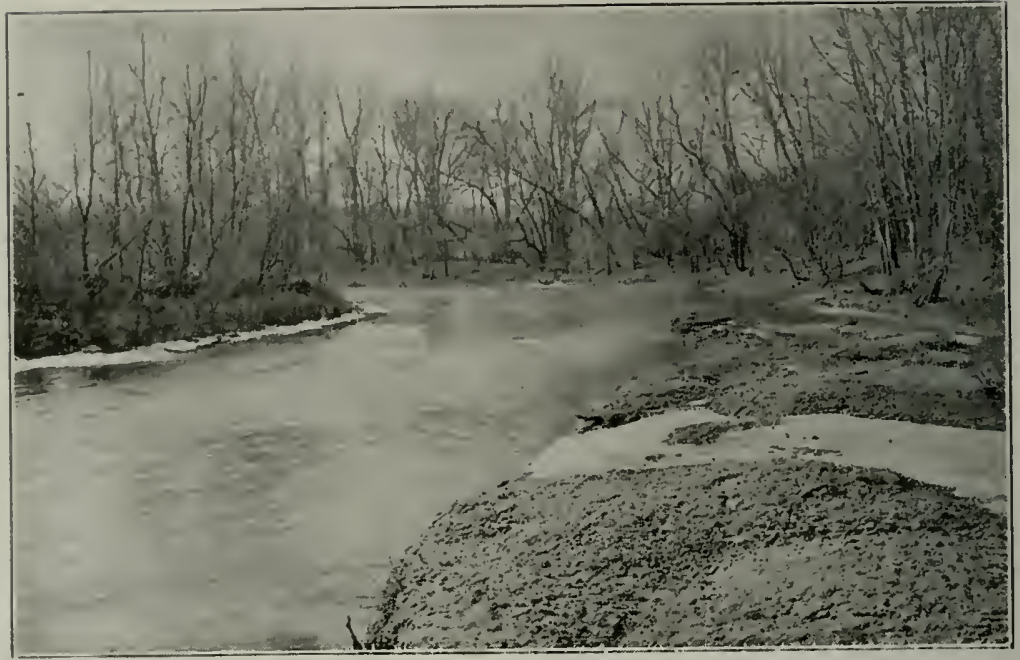

Fig. 4. View of the Salt Fork near Oakwood. Station O (in river) and Station I (mouth of brooklet at rocky edge of river). Habitat of Tarniopteryy nivalis (Fitch), strophopteryx fasciata (Burmeister), Allocapnia vivipara (Claassen), and A. granulata (Claassen). December 27, 1928 .

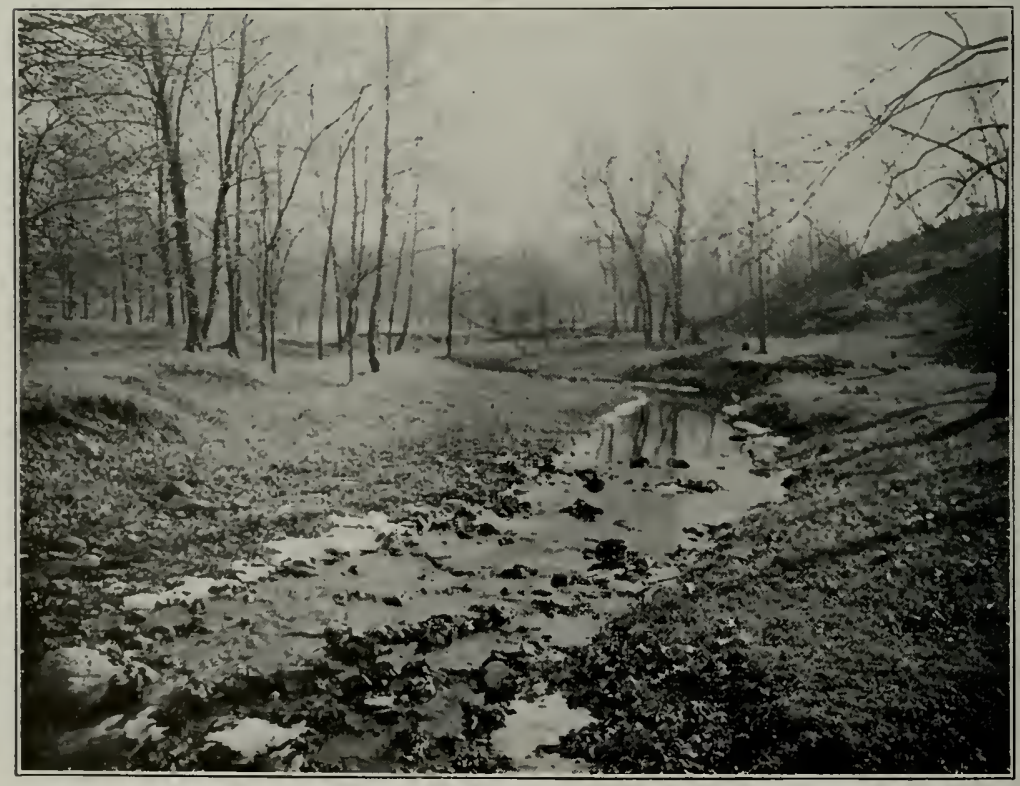

Fig. 5. View of Station VII, a small stream that flows into the Salt Fork about one mile below Station I. Habitat of Allocapnia mystica Frison and A. vivipara (Claassen). December 27, 1928. 


\section{ACKNOWLEDGMENTS}

As in most investigations, the writer has been aided indirectly by the revious studies of other investigators and directly by various individuals. Iy assistants, Mr. H. H. Ross and Mr. A. R. Park, Jr., have been of ervice in the collection of material and in other ways. I an indebted o Dr. P. IV. Claassen, of Comell University, for a review of my identifiations of adult specimens of certain species of stoneflies involved; to Ir. Samuel Eddy, of the Lniversity of Illinois and the Natural History inrey, for a determination of the small organisms used as food by the

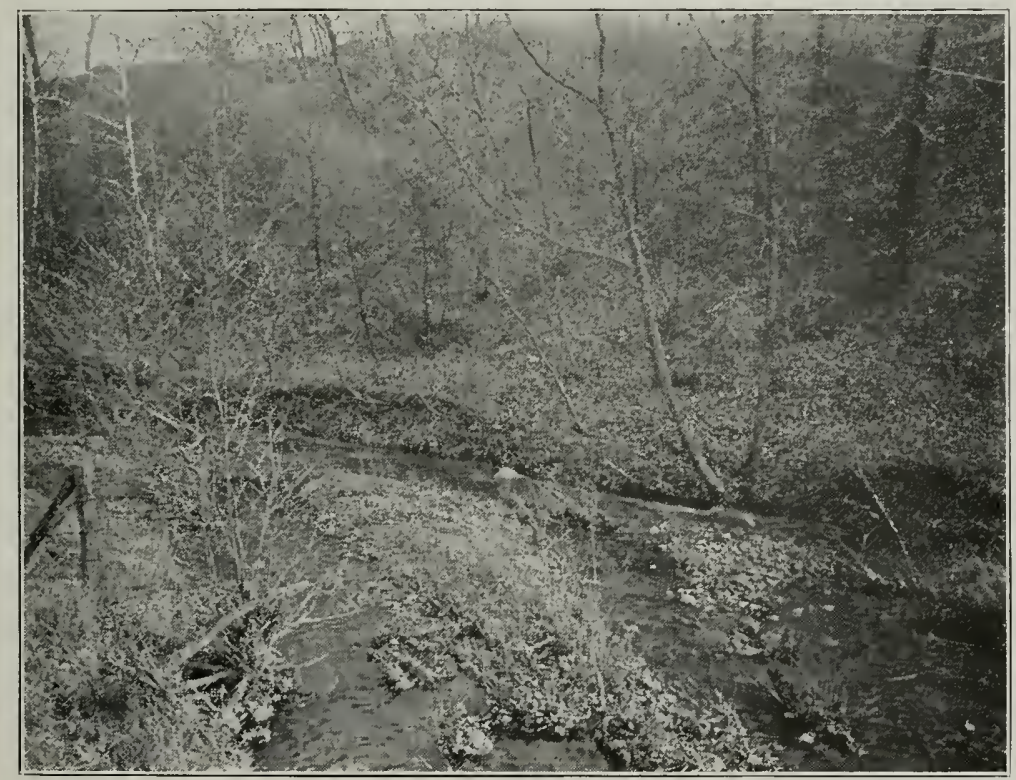

Fig. 6. View of a small tributary of the Middle Fork north of Oakwood. Habitat of Allocapnia vivipara (Claassen). December 27, $192 \mathrm{~S}$.

1ymphs; to Mr. Carl Mohr, of the Natural History Survey and to Mrs. §. H. Paul, of the University of Illinois, for the preparation of the drawngs ; to $\mathrm{Mr}$. A. G. Eldredge, of the University of Illinois, for the photoraphs; and to $\mathrm{Mr}$. H. C. Oesterling, editor of Survey publications, for aling care of the final details incidental to the publication of this paper. Mention should be made, too, of the aid given by Dr. R. D. Glasgow and is companionship on many of my unofficial week-end trips to the Oakrood region. 


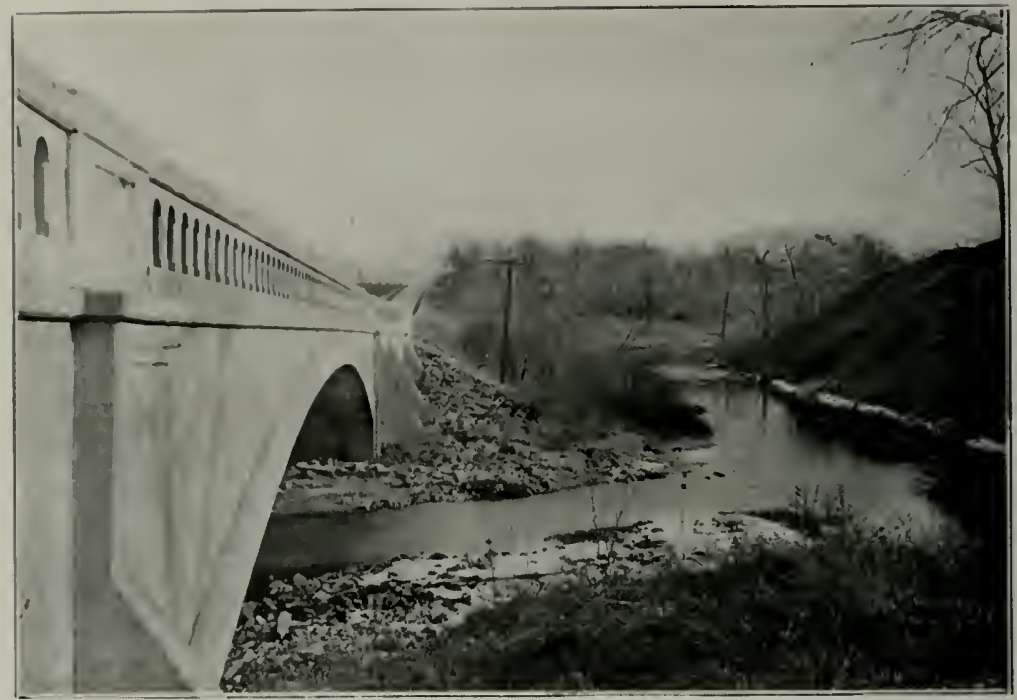

Fig. 7. View at bridge over Stony Creek on State Route 10, east of Muncie. Adults of fall and winter stoneflies congregate on sucl bridges. December 27,1928 .

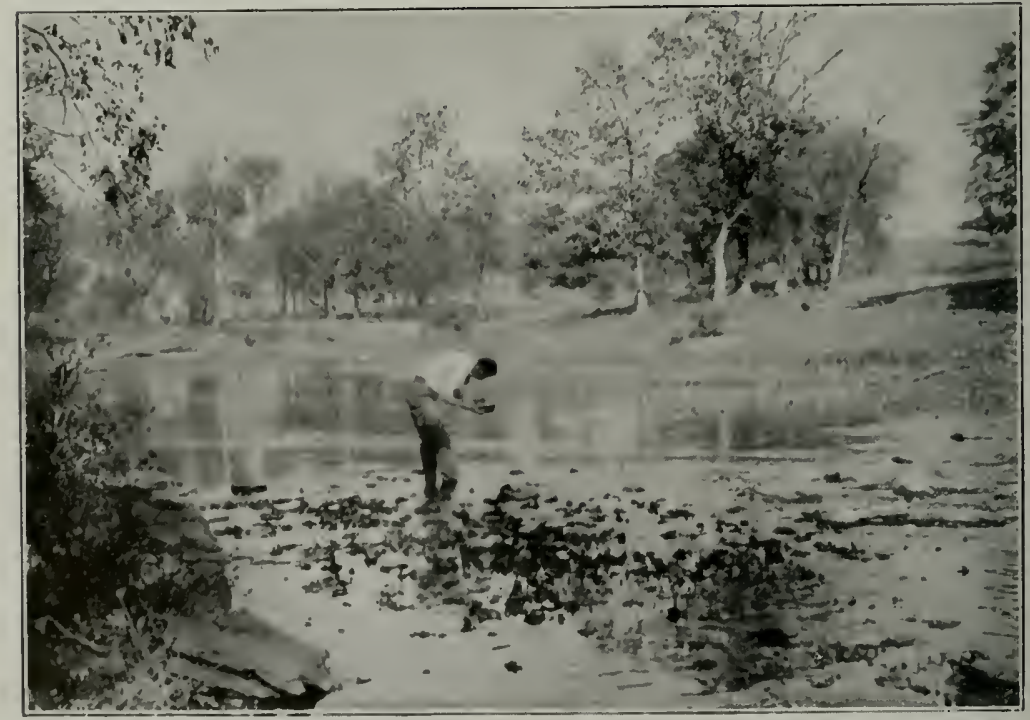

lig. S. View of Stony Creek east of Muncie, Illinois, October 25, 1927. Nymplis of T'usviopterys nivalis (Fitch) very abundant in partly submerged leaves lodged against rocks. 


\section{BIOLOGY}

To date, the writer has collected and closely studied six species of stoneflies from Illinois which are to be truly assigned to the fall or winter insect fauma. Two of these, miralis (Fitch) and fasciata (Burmeister). are moderately large $(13-16 \mathrm{~mm}$.) and belong respectively to the genera Tacuioptery Pictet and Strophoptery'r Frison. Four forms, mystica Frison, recta (Claassen), granulata (Claassen) and rizipara (Claassen) are comparatively small ( $(j-10 \mathrm{~mm}$.) and belong to the genus. Allocapria Claassen. All of these species have their most rapid nymphal growth at various times during the fall and winter months and reach adulthood in Illinois during late November. December, January, February, or March. A few stragglers are still to be found during the first of April, but the peak of their abundance and the time of their greatest activity is then past. In adclition to those just enumerated, four species-Tacuioptery pare'ula Banks. Leuctra claasscni Frison. Allocapnia pygunca (Burmeister), and Allocapnia forbcsi Frison-have been collected in the adlult stage in this state during the winter season, and sufficient information obtained to show that they belong to the true winter fama. The nymphs of three of them, T. parrula, L. claasscui, and A. pygmaca, have been discovered for a certainty and some biological data secured concerning them. One other species, an undeterminable species of the genus Capnia Pictet. was collected during the first part of March and probably belongs to the true winter insect famna. The latter cannot be positively named to species at the present time because it is represented in our collection by a unique female specimen, and thus far no one has been able to separate the various females belonging to this genus or to properly associate them with the easily differentiated males. Because Capuia zornalis Newport is the only species of this genus occurring east of the Rocky Nountains. it is likely that the Illinois specimen in question is this species or new.

\section{Seasonal Adjustments}

Numerous collections and observations in the Oakwoorl area lave demonstrated that there is a rather (lefinite succession in the time of appearance of the adults of the various species of fall and winter stonefieand that all of them have one generation a year. One other North American stonefly (Ncmoura r'allicularia Wu) has been founcl by Wu (1!r:?) to have one generation a year. In Europe, Mlertens (1!):3) and Schoencmund (19).) have shown that several small forms inhaliting streams, and closely related to those mentioned in this paper, have a single generation a year. Accordingly, a generalization can be drawn that small plecopteran species, particularly those appearing in fall and winter, have a single generation each year in contrast to the larger species flying in spring or summer which nua require two or three years for their rlevelopment. During the past two years I visited and made extensive collections and olservations no less than twenty-eight times at Stations I, II, 111, and $I V$ in the Oakwood area. On these trips over four thousand 
specimens of adults and nymphs were collected and later critically studied. while numerous other specimens were observed but not collected. The number of specimens studied is sufficient to preclude a misinterpretation of the seasonal suceessional data, at least concerning the adults of five species occurring in the sane locality. The fact that the aclults show a marked succession in time of their emergence is indicative, also, that there are corresponding differences in the length of the egg and nymphal stages. such information as has been gathered regarding this subject is presented under a discussion of the labits of nymphs.

In 1!) 2 ti, the first collection at Oakwood was made on November ?s. lixcept for onc on December 1 , no further collections were marle until February : 1. 1!?: after which numerous collections were made until the winter stomeflies disappeared. The late date of starting in the winter of $1 ! \cdot:(j-2):$ and the long interval between the first and later observations. preclude the use of these data alone for evidence of a definite succession of species.

The years of $192:$ and 1928 . however, have supplied sufficient data from which to draw reliable conchusions. Search was made for the first stages of the winter stonefly nymphs at various times and at various stations during the smmmer months of $19.2 \hat{2}$, and beginning on September 1. frepuent collections were made to determine the matter in question.

Without going into great detail or presenting a tabulation of all the finclings, it will suffice here to report only the gist of these records and observations under the specific name of each species of fall or winter stonefly found in Illinois. The status of two species as true representative of the winter fauna is possibly open to slight question, but since all available evidence suggests that they are true winter stoneflies, they should be considered along with the others.

\section{Allocapnia recta (Claassen)}

In 1926, as well as in 1927 and 1928, the first adults found at any of the Oakwood Stations belonget to A. recta. the smallest of all the fall or winter stoneflies I have studied. Adults were found at the very beginning of my stulies on November 28,1926 . In the late fall of 1927 , adults were first discovered on November 20, and in 1928 on November 18, and it was evident from their numbers and proved by subsequent collections that the period of their emergence hai just started. The maximum abundance of the adults was in December, both in 1927 and 1928. After this month the number of adults present rapidly declined, and by the last of March the species was comparatively a rarity.

Since no specimens of this species have been collected in Illinois outside of the Oakwood area, no data are available for comparisons with seasonal adjustments in other parts of the state. Collecting trips in November, Narch, and the first of April to various parts of the state have failed to produce a single specimen of this species-an indication that if $A$. recta occurs in other parts of the state, as it surely must, it is a rarity. This species is apparently the earliest of our winter stoneflies to reach maturity, arriving at its maximum abundance in December and thereafter gradually diminishing in numbers until there is no readily discernible evidence of its presence. 


\section{Allocapnia rizipara (Claassen)}

1. vivipara is the next species to appear on the scene in the Oakwood area after 4 . recta has made its début, but the emergence of the adults is not so concentrated or uniform. A few specimens, mostly males, were found during the early part of December in 1927 and the latter part of the same month in 1928 . but the time of their maximum abundance was not reached until the first or second week of March. By the last of March only a few stragglers were to be found.

Collecting in various parts of Illinois has confirmed the main generaliza. tions concerning the seasonal adjustments of the adults of this species as worked out for the Oakwood area. Adults of this species were taken in December at Ft. Sheridan, the typic locality of the species, and hundreds of them were taken in various parts of the state in February and March. In the vicin. ity of Barstow (northwestern Illinois) they were apparently at their maximum abundance on April 2, 1928. This was about two weeks later than the late for the naximum abundance at Urbana (central Illinois), and about a month later than at Herod (southern Illinois in the Ozarkian Uplift).

\section{Allocapnia gramulatu (Claassen)}

Unlike either $A$. rect $\ell$ or $A$. vivipar $t$, no specimens of $A$. granulutu have been taken in the Oakwood area in the month of December. In January, on mild days when crevices appear in the ice along the river bank and a little open water is to be found here and there, the adults of this species come forth to crawl about on the rocks, snow, or ice. Although they are common in January under certain conditions, the main concentration of them comes during the latter part of February and in March, and a few can still be found during the first of April.

In southern Illinois only a few specimens of this species were found on March 5-7, 1928; if the species was abundant there, its maximum abundance had passed some weeks previons to our trip. In northern and north-central Illinois, some specimens were collected during the last of March and the first of April.

\section{Allocapnia pygmaca (Burmeister)}

All of the species of $A$. pygmrea taken in Illinois have been from the extreme southern part, in the region of the Ozarkian Uplift. They were collected on March 6-7, 1928. Sufficient data are available from collections in other parts of the state, especially the Oakwood area, to prove that this species is essentially an element of the fauna of southern Illinois. Since this was the dominant species in March, 1927, and no adults were found at the same localities in Ncvember, 1928, it evidently reached its greatest abundance about the first of March. Probably some specimens appear in January and February.

\section{Allocapuia mystica Frison}

Although A. mystict was not discovered until the late fall of 1928, there is ample evidence that it is a true member of the fall fauna. It was common when first found near Oakwood on November 18. A few days later at the same place the adults were exceedingly abundant and continued to be so during the first part of December, but by the end of that month the maximum of their 
abundance had passed and they were diminishing in number. In southern IIIi. nois this species was found to have the same seasonal adjustment as in central lllinois; it was very common the last of November in the vicinity of small streams where it had been found very rarely or not at all in March of the same year. The few adults collected in southern Illinois in March, when A. pygmaca and $t$. vivipara were the dominant species, were merely stragglers out of step. for some reason or other, with the usual time of appearance of the species. The same is true, also, of the adults found in the Oakwood area in February.

\section{Allocapria forbesi Frison}

This easily recognized species, new to science, was first found at two separate southern localities (Stonefort and Cobden) on March 4-7, 192S. Since only four specimens were taken at this season, it was surmised either that this was the rarest of the lllinois species of Allocapnia or that the time of the maximum production of the adults was in fall. Collecting near Herod in November, 1928, demonstrated that $A$. forbrsi is a true member of the fall fauna and that the specimens collected in March were stragglers. Since no members of this genus were found in the adult stage when this territory was visited on another mission in the latter part of October, 1928, it is evident that they first appear in November.

\section{Tacnioptery nizalis (Fitch)}

This moderately large species is distributed thronghout Illinois and is our most abundant species. To date, specimens have been taken in more than fifty different places, and there is apparently no reason why $T$. nivalis could not be collected in any county in the state during February or March. In 1928, a close watch was kept in the Oakwood area for the appearance of the first adlults of this species, with the result that a few were collected as early as Jannary 2. From this time onward, an increasing number of adults were to be found during the warmer parts of the milder days; the maximum abundance, however, was trom February 11 to the middle of March. Afterwards their numbers gradually diminished, and though some were still to be found the last of March, they were but a remnant of the countless horde that earlier basked in the sunshine on the trestle works of an iron road bridge, swarmed over stones at the river's edge, and crawled over tree trunks in search of food. Data for 1927 indicate the same seasonal adjustments as just presented for 1928, and quantitative sampling on February $26,192 \tau$, revealed that $T$. nivalis then outnumbered s. fasciata by about 10 to 1.

In northern lllinois the time of the maximum abundance of the adults is no cloubt later than for the Oakwood area, as shown by the capture of adults and even nymphs on our northern trip during the first week of April. The reverse of this may be said for southern Illinois, because on our southern trip, March 7-9, ample evidence was obtained that the maximum abundance of the adults was past. No adults were to be found, however, in southern Illinois at the time of our fall trip the last of November, 1928.

\section{Tacnioptery'r parcula Banks}

Since T. parvulu is lacking in the Oakwood area and is not numerous in other localities in Illinois, no consecutive data are available for comparative 
studies of its seasonal adjustments. Specimens have been taken at six localities along the Rock River in northern Illinois, at Grayville along the Wabash River, and at Elizabethtown along the Ohio River. Apparently this species is confined to the larger rivers, and further collecting should produce specimens from localities near the Mississippi and the Illinois. The earliest record we have for this species is March 7 and the latest record is April 23.

\section{Strophoptcry'.1 fasciata (Bumeister)}

Although never as abundant as T. nivalis in the Oakwood area, S. fasciatu is a common winter stonefly in Illinois and has been taken at thirty-one different places. This species does not appear as early as nivalis. its earliest record from Oakwood being on February 3, 1928. Its maximum abundance at this locality in 1927-28 was reached during the last half of March, so that it was the dominant species after nivalis had passed along.

Additional data were found in other sections of lllinois showing that the maximum abundance of fasciata follows that of nivalis. At Grayville, Illinois, visited on our southern trip on March 8, 1928, nymphs as well as adults of fasciata were collected, the nymphs being particularly indicative of the lateness of appearance of the adults. Nearly a month later at Rock Island, in northwestern Illinois, the adults of this species were very numerous and T. nivalis almost a rarity.

\section{Leuctra claasseni Firison}

This new species is undoubtedly a rarity in Illinois and unlikely to be found outside of the southern part of the state. The two adults and ten nymphs, the specimens from which the species is described, were collected in a small rocky stream near Herod, Illinois, on March 8, 1928. Exact information regarding the maximum abundance of the adults awaits further investigations. Judging by the size of the nymphs, which were not common, the adults were just beginning to appear.

\section{Capnia sp.}

Evidentiy another rare species in Illinois and probably absent in the northern part of the state. Unidentifiable to species for the reasons previously stated. Aside from its probable place in the winter fauna, nothing is known of its biology.

\section{Habitat Preferences}

The blanket statement that the nymphs of stoneflies are aquatic has generally sufficed in the past as a summary of their habitat preferences. Ratler recently in Europe, where the most work on the biology of the stoneflies has been done, a good beginning in the association of nymphs with definite habitats or communities has been made by Neeracher (1910), Rousseau (1921), Mertens (1923), and Schoenemund (1925). In America, less has been done; only a few statements regarding habitat preferences are in our literature (Smith, 1!)13 and 191\%, and Wu, 1923), and almost nothing in a comparative manner has ever been attempted. Increasing interest in studies of the biology of river systems and their tributaries will no doubt eventually lead to a good ecological classification 
of them, and with the conning of this more exacting nomenclature there will he at struger denland for the proper assignment of the various organisms living there to the many communities represented.

Considerable information was obtained during the last two years regarding the grosser habitat preferences of the nymphs of the fall and winter stoneflies of lllinois, particularly the six species found in the Oakwood area. Since these insects spend the greater part of their lives in the nymphal stage, in which they are nost dependent mpon a relatively stable or fixed environment, this stage has been considered as the best or truc criterion of their basic habitat preference.

\section{TAENIOPTERYX and STROPHOPTERYX}

In the area represented by Figure 4 the nymphs of five species of fall and winter stoneflies can be collected within a radius of fifty feet, but there are, nevertheless, certain marked differences in habitat preferences among these species. The nymphs of $T$. nivalis and $S$. fasciata are never found in the small brook flowing into the Salt Fork, except when a few of them are carried by floods into Station II and stranded there with the return of low water. On the many occasions that I have visited this area when the adults of Tacniopteryx and strophopteryx were flying and laying eggs. I have never seen them deposit their eggs at Stations II, III, or IV, but always in the middle or near the edge of the river itself (Station $O$ ). The collection of nymphs and adults of Taen. iopteryx and strophopteryx in various parts of the state has furnished additional evidence that the members of these genera in Illinois prefer the larger water courses which never become dry or reduced to small pool stages during the summer or fall of the year.

It was likewise found that the nymphs of $T$. nivalis and S. fasciata are not identical in respect to the community in which they prefer to develop, aside from their common preference for a permanent water flow in streams ranging from the size of the Salt Fork, near Urbana, to such large rivers as the Wabach, near Grayville. The nymphs of $T$. nivalis are especially abundant in clusters of decaying leaves which, when falling or washed into the river, are caught and held by the current of the stream against rocks and willows or lodged against the shore (Figure 8), and then later submerged or partly submerged in water and silt. The nymphs of $S$. fasciata, however, seem to have an antipathy for nuddy debris of this character, preferring to crawl about small stones and pebbles in clearer water. When the water is very clear they may be seen at Oakwood (Station I) crawling around on the rocky floor of the river. It zeems probable that the amount of dissolved oxygen or the hydrogen-ion concentration is different in these two situations and that $T$. nivalis is able to thrive by virtue of its extraordinary coxal tracheal appendages (Figure 41) in situations where $S$. fasciatt. which lacks such appendages, is at a disadvantage. Although the biology of nymphs of 7 . parvula has not been closely studied, it has been found that they frequent the larger rivers. Because of their close affinity with nivalis and the presence of coxal tracheal appendages, it can be safely inferred that they frequent situations similar to those preferred by nivalis. 


\section{ALLOCAPNIA}

The species of Allocammia exhibit a wide degree of diversity in regard to the communities which they prefer. In the Oakwood area the nymphs of $A$. gramlata are found both in the river (Stations $\mathrm{O}$ and I) in company with $T$. nivalis and s. fasciata. and also in masses of submerged and decaying leaves in the brook at Stations II and III. They are most abundant at the river's edge and at Station II where the brook is overflowed by the river during high water-always, however, in association with decaying vegetation. Arlitional data showing that grannlata prefers larger streams with a good permanent flow are furnished by collections made in other parts of Illinois. In fact, gramulata has been collected at sufficient localities in lllinois to inclicate its general clistribution within the state, particularly the central and northern portions, and its association with such major river systems as the Rock, lllinois, Sangamon, Kankakee, Vermillion, and Wabash.

A. recta thus tar has been found in Illinois only in the Oakwood area, where it occurs in three small streams within a seven-mile radius. In all cases the habitat is the same-a small blook (Figure 1), with considerable decaying organic matter, usually clear except immediately after heavy rains, and reduced at certain times of the year to small pool stages. The nymphs are found on the bottom of the stream, particularly under and between deposits of decaying leaves. Thus, A. recta differs markedly from A. granulata in respect to type of stream preferred for its development.

A somewhat intermediate condition between $A$. gramulatu and $A$. recta in regard to habitat preference is exhibited by $A$. vivipurf. a species found in all parts of Illinois. At Urbana a few specimens can usually be found in company with 1 . gromulata along the course of the Salt Fork. and the same applies to other rivers in all parts of Illinois where collections have been made. However, our collecting is sufficient to show that the habitat where the greatest concentration of both nymphs and adults are to be found, is a small brook with a sandy and rocky bottom, cluttered with decaying leaves, which may or may not reach a small pool stage at certain times of the year. In the Oakwood area, careful collecting is certain to reveal a few specimens almost anywhere along the course of the Salt Fork, but they are more abundant at Stations II, III, and IV and in other similar brooks. A simildr state of affairs was observerl in the vicinity of Rock Island in 1928, when a small brook near Barstow, with a sandy and rocky bottom, produced seventy-four males, twenty-five females, and numerous nymphs and nymphal skins in a iew minutes of collecting, whereas along the nearby shores of the Rock River the species was rare. A comparable example is known, also, in the vicinity of Mahomet. In southern Illinois, vivipara is abundant in the numerous small streams of the Ozarkian Uplift and, though associated also with the larger streams, is less abundant in them.

Although restricted to extreme southern Illinois, sufficient data have been collected to show that A. pygmara is nearly similar to A. vivipara in respect to type of stream which it prefers. Large numbers of this species were found near Golconda in shallow, stony stretches of the Big Grand Pierre River where 
decaying organic matter had lodged, but it was even more numerous in the small streams (Bushy Fork, Rose Creek, Gibbon's Creek, etc.) in the Ozarkian Uplift proper, streams which reach small pool stages at certain times of the year.

The preferred habitat of $A$. mystica is to all general appearances the same as that of $A$. recta and $A$. pygmae's, except that streams containing mystica have averaged somewhat larger in size though still reduced at times to a small pool stage. The distribution of mystira in the Oakwood area, however, is so freakish that one cannot help wondering whether more subtle factors are operating. Just why mystica does not occur in the small brook at Stations II or IV in association with rectu and vivipara is a mystery, in view of its abundance and association with vivipara in another slightly larger stream emptying into the Salt Fork about one-half mile downstream. A superficial survey of the two streams reveals no marked differences in their physical make-up or watersheds. Considering the low temperature of the water at the time of the nymphal development, a difference in dissolved oxygen content would not seem to answer the question. Perhaps we are here dealing with a merely fortuitous distribution.

When sufficiently abundant, the adults of fall and winter stoneflies: in the aggregate serve as a good guide to the basic habitat of the nymphs. for they tend to remain for a time in the neighborhood where they emerge and the females also deposit their eggs there. This, however, does not hold for individual adults, many of which may be captured some distance from the place of their nymphal development, having wandered or flown far in search of food or aimlessly drifted with the wind. On many occasions I have seen winter stoneflies, particularly the large Tacnioptery.l. flying miles from any place that could have served for the development of the nymphs.

The lack of wings in the males of $A$. iripara, and often their shortness in the females, prevent some adults of this species migrating in any numbers to great distances from the place of their birth. The farthest I have found such individuals from a place where they might have developed. was only a few hundred feet, and then usually on bridges over the strean or on nearby tree trunks. The females of A. gramulata, however, are well equipped for flying and, like $T$. nizalis and $S$. fasciata, nay travel miles from the place of their origin. Although provided with wings, the females of $A$. recta, $A$. mystica, or $A$. plgmaca have never been olsserved flying about over streans as have those of $A$. granulata. When disturbed while feeding on the trunk of a tree or resting on a post or bridge, they half drop and half fly to the ground and often are carried by the wind for a distance of several yards. Judging by the extent of clevelopment of their wings, however, there is no apparent reason why some of them should not fly well. Since the males of $A$. recta, $A$. pymaca. A. mystica, and $A$. forbesi have much shorter wings than the females, the probabilities of their wandering far from their nymphal habitat are reduced. and I have never found them except upon bridges, trees, etc., nearl,y. 


\section{Habits of Adults}

\section{FEEDING}

Smith (1910) in his classical report of the "Insects of New Jersey," stated that adult stoneflies "do no feeding upon living plants as far as known," and Ronssean (1921) in his extensive work on the aquatic larvae and nymphs of Europe said that the stonefly adult "ne prend pas de nourriture car sa bouche est atrophiée." It has been discovered, however, by Newcomer (1918) that several western species of Tacnioncma (nigripennis Banks, pallida Banks and pacifica Banks) feed upon the buds and leaves of plants and that one species in particular, pacifica Banks, sometimes causes serious injury to apricot and peach orchards in Washington. Wu (192:3) has found, too, that some adults of Nemoura vallicularia Wu will feed a little upon parts of the young leaves of the touch-menot (Impatiens).

In view of the general belief that adults of stoneflies which feed are the exception to the rule, it was with considerable interest that I found all of the fall and winter species of the Oalwood area to be feeding. My first intimation of this fact came about in an unnusual manner. On March 5, 19?: some live adults of Tacnioptery.1 miz'alis were collected at Oakwood and brought to the laboratory at Urbana for further observations. Several days later, much to my amazement, I saw the sole remaining live specimen playing the role of a cannibal and feeding upon a dead specimen of its fellow species. After this a careful watch was kept for adults feeding under natural conditions.

On my next trip to Oakwood. March 10 , many winter stoneflies were seen crawling up and down on tree trunks (Figure y) and feeding upon

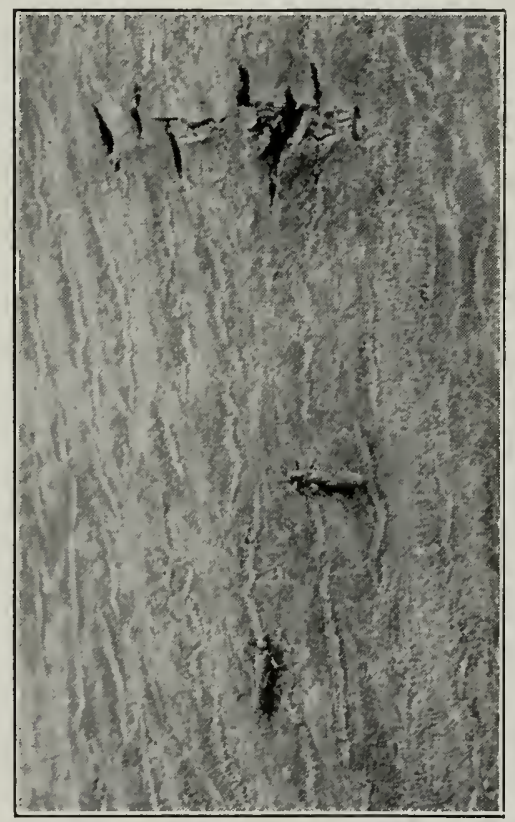

Fig. 9. Adult females of Allocapnia mystica Frison feeding on algae on tree trunk at Station VII, December 27, 1928. blue-green algae (Protococcus z'ulgaris Meneghini) near Stations III and IV. The majority of these specimens were males and females of $T$. niralis and $A$ granulata, the dominant species at the time. A few others proved to be $A$. recta and $A$. vizipara. Many females of $T$. niz'alis and $A$. gramelata, particularly the former, continued their search for food while mat- 
ing with the males, the latter being earried around on their backs wherever they went.

In 1!9s. on many occasions near Oakwood, the adtults of $T$. niz'alis, A. recta. A. atioipara. A. mistica, and A. granulata were observed feerling njom blue-green algae growing on tree trunks, stones, old logs. ete. near their habitats. Becanse of the fact that $S$. fosciuta was not found at Oakwood feeding in company with the other fall and winter stoneflies. a careful search was made elsewhere. This search was finally rewarded on April 3, 19:8s, when thousands of this species were found feeding on the blossons of elm trees near Grand Detour on the Rock River. The elms were so situated along the river and next to the road that one driving on the road was nearly on the level with their topmost branches where the adults were feeding. It seems probable from this observation that the achlts of fasciata prefer to feed in the tops of trees, and some of the many large winter stoneflies seen from the ground in the tops of trees in the Oakwood area were likely the species fasciata. In addition to the species already mentioned, I have observed many adults of $A$. pygmaca and $A$. forbesi feeding on algae on tree trunks, fence posts, and stones near the hahitat of the nymphs in the Ozarkian Uplift, and a single specimen of T. farcula feeding on algae on a tree trunk along the Rock River at Dixon.

It has thus been found that all Illinois species of Tacnioptery, Strophoptery, and Allocapnia take food when in the adult stage. Information concerning the rare winter species, Lenctra claasscni and Capnia sp., is still lacking, but in view of the development of their mouthparts and the habits of other species. I believe that they also feed. Whether the fall and winter stoneflies, especially the females, must feed in orcler to carry on their life processes, has not been conclusively proved. In cages in the laboratory the adults of Allocapnia vizipara and mystica, particularly the females, are voracions feeders, and moder natural conditions they devote themselves most zealously to the same task. When one considers that the adults may live a month or more under natural conditions, that on many days they are very energetic for hours at a time, and that the females produce a very large number of eggs, it seems that the adults feed from necessity and not because of an idle inclination or impulse. If a few more of the Illinois species of stoneflies appearing as adults in spring and summer are found to feed, the current and general statement that most adults of stoneflies do not feed must be reversed.

Although Newcomer (1918) reports that Tacnioptery-x (= Tacnioncma) has calsed scrious injury to buds of fruit trees and even to the fruit itself in Washington, it is likely that such damage is very rarely, if ever, caused by near allies in Illinois. This statement is based mainly upon the fact that most of the winter stoneflies of Illinois reach their greatest abundance before most fruit trees are sufficiently advanced to permit injury and because of the rather local and restricted distribution of the insects. It is interesting to note, however, that Newcomer's figures of peaches showing injury are reminiscent of the so-called "cat-facing" produced on peaches in Illinois by various hemipterous insects. 


\section{MATING}

Mating of the fall and winter stoneflies of Illinois talies place cluring the daytime. and particularly on comparatively warm days when the sun is shining. As soon as the adults of a species become abundant, mating pairs can be seen resting on the concrete foundations of bridges, on tree trumks, or stones, etc., near the water's edge. The time at which mating reaches its maximum varies with the species and has a direct correlation with the seasonal adjustments of the adults. It is not surprising, then. that mating pairs of $A$. recta and A. mystica have been found in the latter part of November, and those of $A$. vizipara during the middle of December. Mating pairs of $T$. mizalis, A. rizipara, and A. gramulata are very common near Oakwood beginning the latter part of February, but those of $S$. fasciata are less frequently seen, perhaps because of their preference for the higher parts of trees while feeding.

During mating, the male rests upon the back of the female, with the middle portion of his abdomen dropped below the level of hers and with the end segments recurved forward and upward again, grasshopper fashion, so that the genital structures of the male and female come into apposition. When an unengaged male approaches a mating pair, the male already in possession of the female spasmodically vibrates his wings as if to scare or knock away the intruding male. Occasionally, too, the males nove their antennae forward in line with those of the females and vibrate them rapidly. It is very apparent from the degree of coloring of the body, flabbiness of wings, and comparative attractiveness to the males that most of the females mate soon after emergence-a characteristic of many insects. The maximum abundance of the males is attained before the maximum abundance of the females. and this proterandry is a wise provision of nature since the females mate very early in life. It was observed at one locality in the Oakwood region (Figure (i), where only -1. rivipara has been found, that the males sometimes mated with the females within a few minutes after the latter had left their nymphal toggery. After once nuating it is doubtful whether copulation is repeated by the females. In the laboratory in cages containing males and females of $-\mathcal{H}$. siripara, the latter known to have mated soon after emergence, the males continued now and then for many days to ride around on the back of the females while attempting to mate. but they were never again observed in actual copulation.

\section{ONIPOSITION}

A marked difference in egg-laying habits was found to exist in the Oakwood region between the species of fall and winter stoneflies inhabiting large streams and those living in small brooks. Those preferring large streams, such as T. mizalis, S. fasciata, and $A$. gramulata, usually deposit their eggs directly in the river, particularly at rapids where the swirling and turbulent water sparkles in the sunshine on bright days. A short time previous to the deposition of the eggs (Figure 10 ) the females of these species seek resting places on bridges, trees, and other objects near 
the river and by a rhythnic contraction of the abdomen gradually force from the oviduct. a little at a time, a matrix containing many eggs. One such egg mass, produced by a female of $T$. mizalis, contained $140 i$ eggs: and it is probable, judging by their size, that most eger masses of T. miralis, $S$. fasciata, and .H. gramulata contain approximately the same number.

These three species differ, as a rule. in the manner of holding the egr mass while it is being formed. The female of $S$. fasciata keeps her ablomen extended for its full length almost horizontal, or parallel with the object on which she rests, so that the egg mass. which is rather irregular in shape, is partly concealed beneath the abdomen. T. micalis, and to a still greater extent $A$. granulat $a$, bends the end of the abdomen upward and forward, so that the usually globular egg mass is much more easily seen and a superficial observation might eause one to th:nk it was being carried (n) the back of the abdomen.

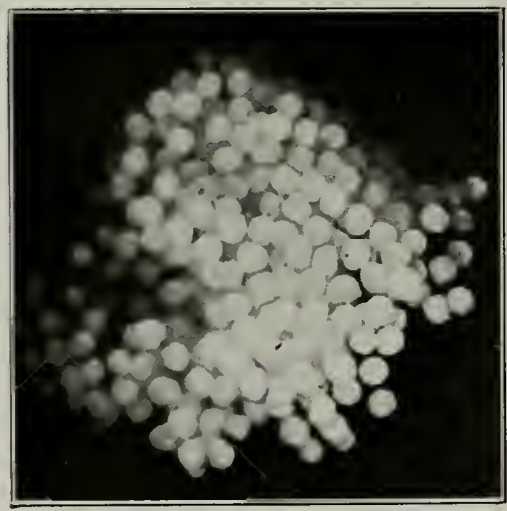

Fig. 10. Eggs of Taeniopteryx nivalis (Fitch).

By the simple expedient of catching females with egg masses and submerging them in water, it was found that the egg masses soon fall from the female, the matrix holding together the numerous eggs dissolves, and the indiviclual eggs separate. Subsequent observations showed that the females could voluntarily release the egg masses when ready to do so, without awaiting the disintegrating effect of the water. It is possible that the egg masses are sometimes dropped into the water by the females without alighting upon it, but in the instances witnessed at close range, the females lighted upon the surface of the water, almost instantly released their egg masses, and then flew up and away again. No doulut, sone females of Tacmioptery and Strophoptery crawl with their egg masses to the water's edge and deposit their eggs., and I have seen stich a performance upon the part of a female of $A$. gramulata.

Unfortunately for the individual, but of no consequence from the standpoint of the preservation of the species. some females after alighting upon the surface of the water and depositing their egg masses become ensnared by the water. and if they do not come into contact with sone object upon which they can crawl out of it, they eventually drown. On lebruary $2 i, 1928$, at Oakwood. I made a ten-minute collection of stoneflies floating on the water past the rocks at Station I with the following results: it $q$ and $\delta$ of $T$. nizalis, $\$ 1$ $q$ and 5 of $A$. gramilate, and $t q$ and 3 of of $S$. fasciata (not abundant at the time). This collection bears mute testimony to the numbers of females that fail to rise 
from the water again when once they descend to it to lay their eggs. Drowning with winter stonefly adults, however, is a slow process, and I have seen many of then slowly walking on the botton of the river near its edge or crawling about under small drifting ice floes.

I have seen numerous fenlales of $A$. rocta and $A$. mystica with sinilar egg masses produced and carried in essentially the same manner as described for A. granulata. Several counts of the eggs produced by single fenlates of $A$. mystica gave an average of about six hundred eggs per tenuale.

Because A. rizipura has been stated to be viviparous by Claassen (19.24), who records that nymphs as well as eggs were found in the abdomen of a iemale. a special effort was nade to get information abont this species. A large number of freshly emerged and mated females were collected in December. 19.25 . and isolated in the laboratory in a cage containing their favorite food-the alga Protococcus a'ulyaris-muder conditions as nearly as possible suitable for the continuation of their life span. In this cage eleven females produced egg masses characteristic of the genus. One of these females was observed in the act of ejecting the eggs. She tilted the end of her abdomen npward only slightly. so that the egg mass did not appear to be carried on her back as is the case with the other species of Allocapmiu in the Oakwood area. In fact, the peculiar fusion of the serenth and eighth rentral abdominal segments may prevent the eggs being hoisted over the back of the abdomen. Dissection of fifteen females of $A$. aivipara revealed no nymphs. but only eggs, the number of which varied from 211 to $41 \%$. Some of the egg masses of $A$. rizifara were deposited in drops of moisture condencing on the sides of the acprarium jar serving for their confinement, and others were laid directly in a mall tin containing water which was placed in the cage expressly for this purpose. These observations inclicate that the name riripara is a misnomer, or at least the viviparons habit is not well established. When dissecting the abdomens of females in order to make a comnt of the eggs, it was fonmd that the embryonic nymphs of this species are in a rather arlranced stage when the eggs are laid. This has suggested the possibility that the nymphs observed by Claassen in a dissecterl female were discloserl by the accidental rupture of the egg shell. Additional and indirect evidence that rizipara is not viviparous is found in the fact that some eggs of this species placed on January 10 under suitable conditions for the emergence of the nymphs harl not hatched by January 29 ; this is an indication that after the eggs are deposited in the water some time must elapse before the nymphs are sufficiently developed to emerge.

Much evidence was obtained in the Oakwood area to show that the females of $A$.recta, A. mystica, and $A$. rizipara rarely, if ever, fly over the brook in which they lay their eggs, and that they deliberately crawl into the water at its edge or at other places where stones, sticks, and leaves are partly submerged. Several times I fonmel females of $A$. rectu carrying egg masses into the water to release them. Since the females of $A$. irifipara are normally short-winged in this part of Illinois, it is easy to understand why some of them do little if any flying above the small 
streams in which they lay their eggs. but in southern Illinois where there is a strong tendency for the females of this species to develop long wings, there is no such restriction upon their flying. There seems to be no good reason why $A$. recta and $A$. mystica to not fly more than they do.

\section{Miscellaneous Adjustuents}

Although the adults of the fall and winter stoneflies of Illinois are obviously tolerant of cold weather, their activities are retarded by very low temperatures and accelerated by higher temperatures. During miclwinter a warm bright day or a succession of such days is sufficient to cause flying, feeding, mating, and other activities, and the return of colder weather is the signal for their curtailment. For example, on February $24,192 \%$. with an air temperature of $58^{\circ} \mathrm{F}$. about $1 \mathrm{p}$. m., many adults of Tacnioptery and Allocapnia were mating, feeding, and flying at Oakwood, but two days later at the same place and same time of day, with an air temperature of $3 r^{\circ} \mathrm{F}$., their activity was greatly diminished, particularly in the case of the large Tacnioptcry.r. Complete cessation of activity of the adults of Allocapnia, however, is not brought about by freezing temperatures. I have seen adults of $A$. recta and $A$. viviparu at Oakwood crawling abont on masses of frozen leaves in the stream and on the ice and snow when the air temperature was as low as $20^{\circ} \mathrm{F}$. During the coldest days of the winter the adults take refuge under flat stones near the water's edge, under leaves, under the bark of trees, and beneath other objects which will provide them with a certain amount of shelter. Sometimes the rapid alternation of warm and cold days leads to their nndoing. Enticed from protecting shelters by comparatively warm days, they may be caught by the sudden return of very cold and freezing weather. As a result, it is no uncommon sight to see adults of Allocapnia frozen tightly in the ice which at times covers the small brooks in this region.

Another feature of the life of the fall and winter stoneflies is the evident proterandry already mentioned. When it is recalled that the males mate with the females very soon after the emergence of the latter. the necessity of this arrangement in the program of stonefly activity is apparent.

The length of life of the adults no doubt varies with the species, time of year, and character of the climate. In marked contrast with certain other aquatic insects - the mayflies, for example, which are often referred to as insects "living but a day"-the fall and winter stoneflies are capable of living for several weelss. Adult males and females of $A$. mystica of unknown age at time of capture have lived over two weeks in the laboratory in cages devised for the observation of egg-laying habits; and certain females of $A$. vivipara, captured within a few hours of their transformation from nymph to inago, have lived in similar cages under rather stimulating temperatures for more than three weeks. Under natural conditions, when periods of cold weather intervene to reduce their rate of metabolism, there is no reason why some females should not live for more 
than a month. Although the data are inconclusive, because of lack of definite information concerning the age of males at time of collection, it appears that the males do not live as long as the iemales: at least. they died as a group sooner than females under exactly the same conditions.

\section{REARING}

The rearing of fall and winter stonetlies could be made a complicated and prolonged bit of experimentation, but for the immediate purposes simple methods have sufficed. It has been an easy matter to collect fullgrown nymph of all the species occurring in the Oakwood region and to keep them alive in small tins containing moist leaves, until the emergence of the adults. A surprising number can be reared in this manner, and the cast nymphal shins preserved for study and comparison with the adults. The same simple technique was employed in rearing adults irom nymphs collected in other parts of the state. Sich a procedure. of course. would not suffice for the exact determination of the number of instars of each species. In order to closely observe the feeding, mating, and egglaying habits, the adults can be kept alive and healthy in small hermetically sealed aquarium jars containing a laver of moist sand. a supply of bark bearing a good growth of green algae. and old leaves and stens on which the adults may rum around or in which they may hide or rest. The eqg: of the fall and winter stonetlies will hatch in glass tubes covered at both ends with fine silk bolting and submerged in unpolluted streams isee p. 36 ) : and no doubt if supplied with the proper quality and quantity of food, the nymphs will develop under the same conditions.

\section{Habits of the Nymphs}

\section{FEEDING}

The feeding habits of stonetly nymphs have been little known. or misunderstood. Is a group they were long regarded erroneously as essentially carnivorous. Rousseau (1921) said of them: "Toutes ces larves. comme le démontre d'ailleurs le sıstème broveur de leur appareil buccal sont exchsivenent carnassières: les jeunes larvules : attaquent aux Infusoires. Oligochetes et petits insectes aquatiques adaptes a leur taille: plus grandes, elles dérorent les larves d'Ephémères. d’Agrioniles. de Trichoptères, etc., mème les larves plus jemnes de leur propre espèce." In both Europe and America this concept of the feeding habits of the nymphs has been undergoing a marked change during the last few rear. Mertens $(19.23)$ and Schoenemund $(1925)$ in Gemant have showi that with the exception of some of the large nymphs of the family. Perliclae most small stonefly nymph are herbivorous and that their food consists of decaying vegetable matter. algae. and diatoms. In Anerica. - 'émour i'allicularia 11 it (a species known only from the eastern states) was tound by IVu (192:3) to be entirely herbirorous: and Needham and Claassen $(19.5)$ added that "stoneflies have usually been considered as carnivorous. 
but the examination of stomach contents of a number of nymphs indicates that Pteronaris's. Nemoura and others feed upon regetable matter only, while Porla, Acroncuria, etc., prey upon animal forms as well as feeding upon vegetable material." These statements are sufficient to show that past idcas of the part played by stonefly nymphs, as an aggregate, in the biology of river systems are no longer tenable.

I careful stucly of the food habits of six species of fall and winter stoneflies in the Oakwood region ( $S$. fasciuta, T. nizalis. A. siripura. $A$. rita, A. mystica. and $A$. gramulata) has demonstrated that these species are essentially herbivorous, the bullk of their food consisting of fragments of decaying leaves, various diatoms, and a few protozoans. Three habitats (Stations I. II, and III) were studied from the angle of possible food occurring there, and samples of the microörganisms living in them were taken on March 5, 1!2:. Full-grown nymphs were also collected there at the same time, and their stomachs were found to contain fragments of decaying leaves and the following diatoms:

Theniopterys nivulis and strophop.

trryx fasciata (Station I.)

Gomphonema slivaceum (Lyngb.)

synedra ulna (Nitz)

Homoeocladia acieularis (Kütz.)

Homoeocladia sigmoialea (Nitz.)

Fragiluria crotonensis (Edw.)

Lysigonium varians (Ag.)

Cocconcis sp.
Allocapnia grenulata (Station iI) Gomphonema olivaceum (Lyngb.) symedra ulna (Nitz.)

Homococladia sp.

Allocapmia vivipara (Station III) Gomphonema olivaceum (Lyngb.) syneura ulnu (Nitz.) Navieula sp.

In order to find out if the food of the young nymphs was different from that of the older nymphs, the stomach contents of some very small nymphs of Allocupnia and Tacnioptery't collected in October, 19.8S. were analyzed, with the following results:

Turniopteryr nivalis (Station I)

Gomphonema olivarcum (Lyngb.)

Gomphonema acuminatum Ehr.

śyncera ulna (Nitz.)

Lysigonium varians (Ag.)

Diatoma vulgare Bory.

Coceoncis placentula Ehr.

1 mphora sp.

Navicula sp.

Gyrosigma sp.

C'yclotella sp.
Allocapnia sp. (Station I)

Gomphonema aeuminatum Ehr.

Synedlia ulna (Nitz.)

Nevicule sp.

A mphora sp.

Cyclotella sp.

The above records of the food of the nymphs of Tacnioptery and Allocapnia, both young and nearly full-grown, are sufficient to demonstrate the similarity in feeding habits of nymphs of various ages and the 
herbivorous habits of the nymphs belonging to these two genera. No doubt a few protozoans are occasionally taken into the alinentary tract along with the diatoms, but the yellow fresh-water diatoms and decaying vegetation constitute their main food. Old leaves which have fallen into the water apparently supply the bulk of clecaying vegetable matter used by the nymphs for food. Streams where Allocapnia or Tacnioptery are abundant are always full of such decaying leaves, many of them as completely slieletonized as those fed upon by Nemonra a'allicularia and illustrated by $W_{u}(19 \% 3$, Figure 12i). Whether the great extent of the skeletonization of old leaves in the small streams of the Oakwood region is entirely due to nymplus of fall and winter stoneflies is questionable.

Although no nymphs of Leuctra classsmi have been critically sturlierl from the standpoint of their food, a superficial examination of one nymph revealed the presence of decaying vegetation. It appears, therefore. that all of the fall and winter stoneflies of Illinois are herbivorous.

\section{EMERGENCE}

When the nymphs of Tacniopteris. Strophoterys, and Allocapuia reach their full development and are ready to shed their last nymphal skin. they crawl out of the water on stones, sticks, leaves, or any other objects which protrucle above its surface. After leaving the water they usually travel but a few inches from it, then come to rest, securely fasten their tarsal claws so that they will not become rlislorlged, and prepare for their last moult. In order that the adults may issue, the chitinous nymphal skin splits along the mixl-clorsal line of the body, beginning at the epicranial arms and extending backward as far as the first abdominal segment (Figure 11). Freed from the nymphal skin the arlults are at first soft and flabby and incapable of flight, but in the course of a short time the wings become riry and completely expanded, the borly and legs become firm and the chitinous parts of the body assmme their normal dark and light colors.

By finding the cast skins of the full-grown nymphs, many of which can be named to species, it is sometimes possible to secure clistributional records for certain localities when the adults for sone reason or other cannot be found. If there is a considerabie lowering of the water level in a river after the emergence of the adults, the nymphal skins may be foumd on tree trunks six or eight feet above the low water level.

\section{DEVELOPMENT}

Practically no information has been publisherl by other investigators regarding the hatching time of the eggs of fall or winter stoneflies. With this in mind a few observations and experiments have been made by the writer regarding this matter. In spite of intensive collections and careful observations aimed to rletermine this particular point in their biology. I have never found the nymphs of Tacnioptery. Strophoptery.1. or Allocapnia under natural conditions before October 10. In view of the fact that all nymphs found in October in the Oakwood region are minute or 
very small, it might be assumed that they do not emerge from the egge until after the summer season hats passed and the water has become cold. This, however, is not the case.

In February, 1!2., I placed an egg mass of a female of $T$. nizalis in a small vial. closed the open end by tying a piece of linen cloth over it. and then placed it in the water at Station $\mathrm{W}$. This vial was not examined again until May ?:2 and then was found to contain very small nymphs which apparently had died from lack of nourishment. A similar experiment was tried in December, 1928. With two egg masses of A. recta in a glass tube covered at both ends with several layers of cheese cloth to perinit a free circulation of water. When one of these tubes (the other was washerl away by the current) was next examined, on January 10, 19:?, no trace of eggs or nymphs could be found: probably they had escaperl through the meshes of the cheese cloth. This same day the experiment was repeated with an egg mass of $A$. aizipara, but fine silk bolting was userl to cover the open ends of the glass tube. When next examined on Jantwary 2?, the tube was found to contain some small live nymphs of irizipara as well as some eggs in good condition abont ready to hatch (breaking them released live nymphs) and some eggs killed by a fungous growth. These experiments are sufficient to prove that the eggs of Tarmioftery and Allocupnia hatch before the water becomes very warm. Evidently, then, the nymphs of these fall and winter stoneflies make little arlvance in their development during the warm season and remain so small that they have been overlooked by all investigators. Since the first instar nymphs are delicate creatures not capable of surviving a drying process. it is a safe assmmption that the species inhabiting very small streams. which are reduced to pools in dry weather, must congregate in the bottom of the pools or in moist places in the stream bed.

The number of instars during the life of the nymphs of the fall and winter stoneflies was not deternined. but because of the fact that nymphs under observation frecpuently molt and that many preserved nymphs of varions sizes show evidences of being nearly ready to molt when collected. I surmise that there are many instars. Wu (199:3) has shown that $\mathrm{Nc}$ moura adlicularia Wu, the adults of which appear in spring, has orer twenty instars. It is cloubtful whether the fall and winter species of Illinois have as many as this, becanse the rapid developmental period of the mymphs is restricted to fewer months.

\section{Morements}

Although no positive information was gathered concerning the territory traversed by the nymphs, it seems likely hecause of their habitat preferences that most of their existence is spent within a limited area. By high water, however, many are dislodged and swept away from places where they would remain under ordinary circumstances. This explains the occasional presence of nymphs of Tacnioptery.r and Strophoptery. in Station II in the Oakwood region. By the same process other nymphs are washed ont of the small brooks into the larger streams. 
Attention may be called at this place to the peculiar movements of the fall and winter stonefly nymphs, which are suggestive of the walking gait of many reptiles such as lizards and alligators. Their gait is usually slow, accompanied by a right and left lashing of the abdomen and tail-like cerci, which drag along behind. Although they are not alone among the aquatic insects in this peculiar style of locomotion, it airls the collector in recognizing the smaller nymphs mon stones, leaves, and other objects under the water.

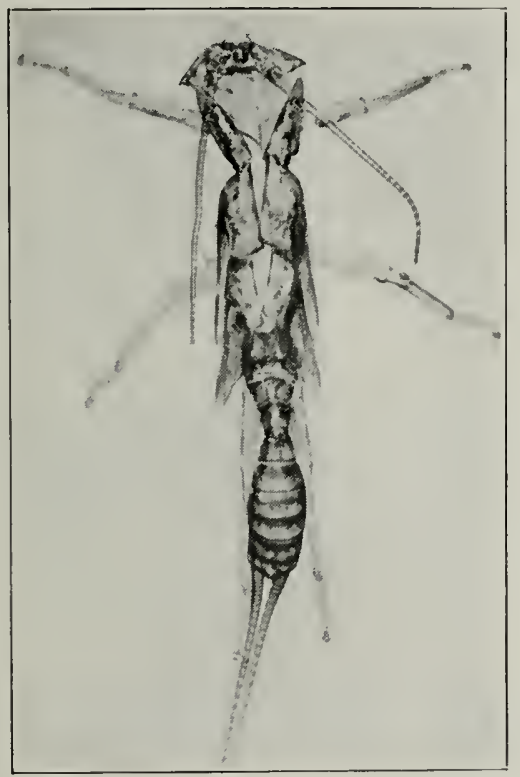

Fig. 11. Dorsal view of cast nymphal skin of female of strophopteryx fasciata (Burmeister).

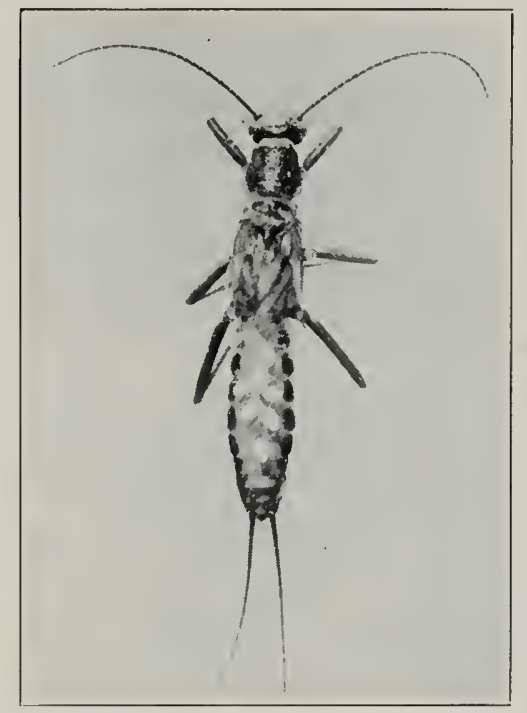

Fig. 12. Adult female of Allocaynia granulata (Claassen) with wings clipped to show attachment of mites.

\section{Enemies}

The fall and winter stonefly nymphs of Inlinois seem to be remarkably free in their later stages from the attacks of predacious or parasitic cnemies. This is no doulst due to the time of the year when their growth is most rapid, as well as to the character of the streams they inhabit, their size, etc. The fact that their greatest development comes at a time of year when fishes feed little, or not at all, certainly is one saving factor, and perhaps this explains why the winter stoneflies appear in enormous numbers although the summer forms are seldom abundant. Yet, since each female lays hundred of eggs, many of the eggs or the early instar nymphs must meet death by varions moletermined means; otherwise even larger numbers of adults would be found. Since certain large stonefly 
momplis and other atuatic insects occupying the same habitats are definite1. know'n to be carnivorous, it is reasonable to suppose that they eat small nymphs of the species which we are considering. No true parasites were found atacking any of the thousands of nymphs examined-an indication that they are very rare if not altogether lacking. Interesting to find, but of little importance in effect, is the fact that growths of Infusoria, such as Operculariu, occur on many nymphs.

The arlults are directly attacked by the immature forms of a water mite (Diplodontus sp., (let. Kuth Marshall) whose biological history is not well known. I have found these small red mites on varions species of Allocapnia from December to the midclle of March. but never on Tacuiopteryor or Strophoptery.t. The mites attach themselves to the achults, preferably on the dorsim of the abclomen beneath the wings (Figure $1 \%$ ), and may cause small scars. Rarely are they abundant enough to interiere seriously with the normal activities of their host, and only occasionally have enough of them been found on a single adult to reduce its vitality or hamper its movements. How they get on the arlults in the first place, as well as what becomes of them when the insects die, is still a mystery.

Although I have never seen birds eating stoneflies in winter nor found any such records in literature. I see no good reason why the adults should $n o t$ be choice tid-bits in the diet of certain of our winter resiclents. In fact, because of the abundance of these insects and their ajpearance on trees at various times fluring winter, it seems that if they are not eatten a rich smpply of food is being overlooked by our feathered friends.

\section{TAXONOMY AND NOMENCLATURE}

While accumulating a collection of the fall and winter stonetlies of Illinois, consisting of some seven thousand specimens of adults ancl nymphs, the writer made particular efforts to collect mating pairs. Is a result, mating pairs of the following species were taken: Tacnioptory.r. niralis (Fitch). Tacnioptory pariula Banlis, Strophoptery fasciata (Burmeister), Allocapuia gramulata (Claassen). Allocapnia plymaca (Burmeister). Allocapuia rizipara (Claassen). Allocapuia recta (Claassen) and Allocapnia mystica Frison. In addition, certain females of Allocapnia have been found in association with males of Allocupuiu forbesi Frison uncler circumstances which leave no doubt as to their specific identity. The possession of these properly associated males and females has given a somnd hasis for the recognition of the specific characters of the females found in Illinois and for the preparation of keys for both males and females. The males, except for the two new species described in this paper, have been previously lieyed to species by Needham and Claassen (19.5). but as far as I am aware no attempt ever has been made to key the females. 
Probably because of the difficulty of properly associating the nymphs with the adults, little has been known about the immature stages of the North American plecopteran fauna, and even the genera have not been adequately characterized. In this respect we are not exactly alone, for in Europe where the plecopteran nymphs have been letter studied, less than one-third of them (Koponen, 191i) have been associated with their adults. Perhaps the most thoroughly investigated region in the world in regard to its stonefly nymphs is in northwestern Germany where Schoenemund (192.5) has been able to associate some thirty-eight nymphs with adults of a total stonefly fauna numbering about fifty species. Is the basis for the recognition and leying of the nymphs of the fall and winter stoneflies of Illinois, none of which have been previously characterized, collections were made of them at every opportunity. From time to time. too, particularly in the Oakwood region, mature nymphs have been collected and the adults reared from them.

Such rearings and collections lave served to remove all doubts regarding the correct generic association of the nymphs with their adults and, with the exception of the genus Allocapnia, for the species as well. The difficulty with the nymphs of Allocapria is clue to the fact that this genus affords an exceptionally good example of a homogeneous group. specific differences in the adults of this group are well marked and constant, but they consist for the most part of genital or accessory genital characters which are not developed in the nymphs in a comparable manner. There are, however, certain characters which permit the ready separation of all nymplis of this genus into males and females and the identification and keying of sereral of the males. Although it is possible for one well accpuainted with the adults and nymphs of Allocapnia from Illinois to name most of the remaining species not included in the key (hecause of knowledge of the seasonal and geographical distribution of the species in the state, streams where certain species are liable to be found, slight in(lications of structural characters later apparent in the adults, etc.), it is impossible to formulate a key which would not at times be misleading to others. Therefore, instead of constructing a key based upon exceptional specimens of full-grown nymphs, in which structural characters of adults can be plainly deciphered in advance, attention is called to such specimens under each species of Allocapnia. The chances of naming the nymphs of this genus, particularly the females. increase with the age of the specimens, and rice a'ersa. Many of the full-grown female nymphs of Allocapuia show in clear ontlines what the ventral structure of the eighth abdominal segment of the adult will be (Figure t0), while others of similar size, lue to a lack of contrasting chitinization at time of capture. show nothing (Fignre 39). In the males, also, a heavily chitinized knob-like structure may be frequently seen beneatl the dorsal integument of the ninth abdominal segment, and in exceptional cases it is so well delineated that the species can be recognized by it. 


\section{T.AENIOPTERYX PICTET (scusu str.)}

Taeniopteryx Pictet, Histoire Naturelle générale et particulière des Insectes Neuroptères. Première Mionographie : Famille des Perlides, 1841-1842, p. 345 .

Genotype T'aeniopteryx ne'bulosa L. by original designation.

Velheloptery $x$ Klapalek, Termeszetrajzi Füzetek, Vol. XXV, 1902, p. 179.

Genotype Niphelopteryx nebulosa L. by original designation.

Nepheloptery $r$ Needham and Claassen, Monograph of the Plecoptera or Stoneflies of America North of Mexico. Thomas Say Foundation of Ent. Soc. Amer., Vol. II, 1925, p. 288.

In 1902. Klapalek recognized certain groups of European stoneflies as genera (Tacnioptery.t, Rhabdioptery'. Ocmoptery.x, and Nepheloptcrix) which were formerly assigned to a single genus (Taenioptery.x Pictet). In our latest American monograph of Plecoptera, by Needham and Claassen $(19 \cdot 5)$, these groups are recognized only as subgenera. but in view of the marked and fundamental differences existing between them, particularly the nymphs, it seems advisable to the writer to consider at least the two gromps represented in Illinois as valid genera. Needham and Claassen (19.5) following Klapalek (1902) considered Taenioptery. trifasciata Pictet (European) as the genotype of Tacnioptery.r Pictet (sensu lat.) : and the same, although in a restricted sense, has been done by Schoenemund $(19 \% 8)$. This was in error, however, because Pictet (1s+1) when erecting Tacnioptery designated Nemoura nebulosa L. as its type in the following language: "Je connais sex especes de ce sousgenre, clont le type est la Ncmoura ncbulosa des auteurs." Although it is true. as Aibarda (1889) states, that Pictet in 1832 did not know the true ncbulosa L.. he later corrected his mistake, so that his reference to nebulosu L. in $18+1-18+2$ was not a misidentification. Very recently a brief note correcting the wrong citation of trifasciata as the genotype lias been published by (laassen (1928), but no mention is made of the nomenclatorial changes it necessitates.

This erroneous conception of the genotype of Tacnioptery.r (scnsu lat.) has led to the wrong taxonomic assignment of the generic name Tacnioplery.r, when either the various related groups were considered as separate genera (Klapalek) or as subgenera (Needham and Claassen). The studies of various European investigators (Reuter. 1904 ; Lauterborn, 19013: and Lestage, 19:0) have shown that the nymph of nebulosa. L. has tracheal coxal appendages. Flapalek erected a new genus-Nephcloptery-1-for nebulosa and related forms in 1902, and Needham and Claassen (1!.2.5) have correctly placed, though as a subgenus, nizalis, maura. and pariula in this complex. Since ncbulosa, however, is the type of the genus Tacnioptery by original designation of its author, it follows according to Article 2 !) of the International Rules of Zoological Nomenclature that the name Tacnioptery'.t be used for the complex containing nebulosu and closely related species. In America, these closely related species are nizalis, parcula and manra. Accordingly, in this paper the generic name of Tacnioptery is used for the Illinois species, mizalis and parinula, species shown by my studies to have tracheal coxal appendages in the nymph as do the nymphs of the European genotype, ncbulosa L. 


\section{BRACHYPTERA NEWPORT}

Brachyptera Newport. On the Anatomy and Affinities of Pteronareys regalis Newm.: with a Postscript, containing Descriptions of some American Perlidae, together with Notes on their Habits. Transactions of the Linnean Society of London, Vol. XX, Part III, 1851, p. 451.

Taeniopteryx Klapalek (scnsu str.), Termeszetrajzi Füzetek, Vol. XXV, 1902, p. 178. Genotype Taeniopteryx trifasciata by designation of Klapalek.

The transfer of the older name Tacnioptcry (1841-184\%) to the genus Ncphoptcry.r Klapalek (190?) containing ucbulosa L., armcoides $\mathrm{Ki}_{p}$., and schocncmundi Mert. necessitates the use of another generic name for the taxonomic group containing the species trifasciata Pict., brancri $\mathrm{K} 1$ p., kcmpuyi Klp., risi Mort., scticormis Klp., and tristis K1p. At first it was thought that a new name night be needed for this group, but Dr. Nathan Banks has kindly brought to nly attention the name of Brachyptcra, proposed as a subgeneric name for the European trifusciata I'ictes and a new North American species, glacialis, by Newport in 18.51. The fortunate original inclusion of trifasciata in Brachyptcra by Newport permits the definite recognition of this genus and the use of this name for those European forms previously called Tacnioptery. Klapalek (scusu. str.). Since to my linowledge no type of Brachyptcru has ever been designated, trifasciata Pictet becomes its type by designation of Klapalek in 1902 (Article 30. International Rules of Zoological Nomenclature). Because glacialis has remained unrecognized, it is indeed a most fortunate circumstance that it, one of the two species originally included by Newport in Braclyptcra, has become excluried as a genotype because of the designation by Klapalek. If eventually there is found an American brachypterous male which can be considered as glacialis Newport, it should be placed in this genus, providing it has a two- or three-branched cubital rein. Since no known American species of Tacnioptery in its broadest sense (Taeniopterygidae of European authors) have been described as having such a vein, no American species can at present be rightfully assigned to this genus.

\section{TAENIONEMA BANKS}

Trenionema Banks, Psyche, Vol. XI1, June-August, 1905, pp. 56-57. $\hat{\delta}$

Genotype Taenionema analis Banks = T. pacifiea Banks by original desig. nation and monobasic.

Taeniopteryx Needham and Claassen (sensu str.), Monograph of the Plecoptera or Stoneflies of America North of Mexico. Thomas Say Foundation of Ent. Soc. Amer., Vol. II, 1925, p. 288.

The North American species nigripemis Banks, pacifica Banks, califormica Banks, grinnclli Banks, pallida Banks, and banksii Needham and (laassen were assigned by Needham and Claassen (1295) to Tacnioptery... (sense of Klapalek. 1902 ) ; but since they cannot properly be placed there for the reason already mentioned (lack of two- or three-branched cubital veins), they must be associated with another generic or subgeneric name. Fortunately, the generic name of Tacnioncma Banks (190.j) is available for this complex. According to Newcomer (191s), the full-grown nymphs of pacifica have no tracheal appendages - a condition which should bold good for all of the species included here if the group is a natural one. 


\section{STROPHOPTERYX new genus}

Type Strophoptery.x (Semblis) fusciuta (Burmeister) original and present designation.

Rhabliopteryx Banks, Catalogue of the Neuropteroid Insects (except Odonata) of the United States. Amer. Ent. Soc., Philadelphia, 1907, p. 14.

Rhabdioptery.x Needham and Claassen, Monograph of the Plecoptera or Stoneflies of America North of Mexico. Thomas Say Foundation of Ent. Soc. Amer., Vol. II, 1925, p. 28 S.

The erection of a new generic name for the complex containing the Anerican species fasciata Bumeister seems necessary to the author. This species was placed by Banks (190\%) in the genus Rhabdioptery. Klapalek and by Needham and Claassen $(1925)$ in the same group but reduced to sulogeneric status. It seems to the writer. however. that fasciata contains just as many or more characters in common with the genus Ocmoptcri:r Klp. and its species locacii Alb., as it has in common with Rhabdiopterin and its species ncylecta Alb. and hamulata Klp. Apparently the presence of an extra costal crossvein, and sometimes two, before the ('nd of the subcosta in the forewing of fasciata has influenced the placing of fasciatu in Rhabdioptery, which is stated to possess two or three such extra crossveins. Ocmoptery is stated and figured as having no extra crossreins, a condition sometimes occurring in specimens of fasciatu. The fact that some specimens of fasciata do not have any extra crossveins is an indication that at least in the species fasciata the extra crossieins are not conclusive indications of generic relationships. In other words, in respect to extra costal crossveins some specimens would exactly fit Rhabdioptery, others Ocmoptery.x. and many fall half-way between. In regard to other structural details, such as the shape of the subgenital plate in the female and the longer anal cerci of the males, fasciata seems to fit in Ocmoptery.r better than in Rhabdioptcry.r. The chief difficulty in placing fasciuta in Ocmoptery lies in the fact that in Ocmoptcry the subcosta ends about in the mijldle of the wing and in fasciata the subcosta continues to about two-thirds of the length of the wing. It seems to the writer that the best purposes of classification are to be served by the placing of fasciata Burmeister in a separate genus to which I assign the generic name of Strophoptery.t and designate fasciata Burmeister as its type (j)resent designation and also monobasic).

This genus may be separated from the other related genera by the following conbination of characters: three ocelli; anal cerci of male with at least six segments; apex of subgenital plate of male bent upwards at right angle, sulogenital plate in female greatly elongated and covering tenth ventral segment: usually one extra costal crossvein before the termination of the subcosta. but sometimes none; first branch of cubitus $\left(\mathrm{Ci1}_{1}\right)$ with a single accessory vein in outer part of fore wing and therefore with only two branches: and a crossvein (possibly $\mathrm{Sc}_{2}$ ) after termination of subcosta $\left(S_{c_{1}}\right)$. Nymph without coxal appendages: glossa of labium (Figure 14) divided by a mesarima which extends as a suture about one-half way to the base of the ligula, and galea of maxillae (Figure 18) with dense patch of short setae at apex. 


\section{Keys to the Genera}

1. Abdominal cerci much reduced, less than nine-segmented, not extending backwards as far as one-half the length of the abdomen (Nemouridae)..2 Abdominal cerci long. with more than nine segments, extending tail-like backwards at least one-balf the length of the abdomen (Capniidae)....4

2. Second tarsal segment less than one-half as long as the first..... Leuctra Second tarsal segment more than one-half as long as the first.........

3. Coxae with small round membranous areas (Figure 29) on ventral surfaces (point of articulation of tracheal appendages in nymphs); cerci of male reduced to a single globose segment; subgenital plate of male (prolongation of ninth ventral abdominal segment) with apical portion not abruptly turned upwards at a right angle; ninth abdominal sternite of female without a long triangular projection.................. Taeniopteryx

Coxae without membranous areas on ventral surfaces (Figure 30 ); cerci of male with at least three filiform segments; subgenital plate of male with apical portion turned abruptly upwards at a right angle; ninth abdominal sternite of female with a long triangular projection...... Strophopteryx

4. Mesosternum with posterior margin of large heavily or darkly chitinized medial area (mesobasisternite) strongly produced backwards (Figure $\bar{i})$; second transverse vein (subcosta) of fore wing uniting with mar. gin of fore wing (costa) much before the cord (more or less transverse line-up of cross-veins and some longitudinal veins beyond midile of wing); anal field or lobe of hind wing large and nearly as long as front

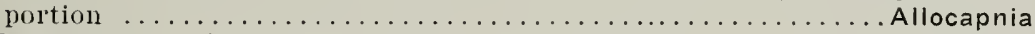

Mesosternum with posterior margin of large heavily or darkly chitinized medial area (mesobasisternite) ncarly transverse (Figure 56); second transverse vein of fore wing extending to or nearly to the cord: anal field of hind wing reduced and not extending much beyond half of length of

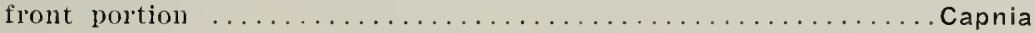

\section{NYMPHS}

1. Second tarsal segment (Figures 25 and 26) approximately as long or longer than the first; somewhat robusc in general habitus; coxae with or with.

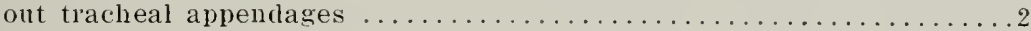

Second tarsal segment (Figures 27 and $2 S$ ) much reduced, not as long as the first; more cylindrical or filiform in general habitus; coxae never

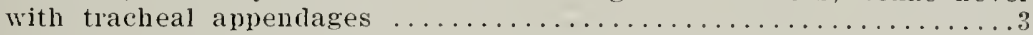

2. Coxae with conspicuous tracheal appendages (Figures 25 and 41); ninth abdominal sternite not produced hackward with a $\mathrm{T}$-shaped projection covering part of tenth segment................. Taeniopteryx Coxae without tracheal appendages (Fignle 26); ninth abdominal sternite conspicuously protuced backwards with a T-shaped projection (Figures 42 and 43 ) covering part of tenth segment............ Strophopteryx

3. Lateral margins of abdominal segments somewhat rounded, segments widest at posterior margin and narrower towards base; glossa of labium (Figure 15) divided by an incision which extends longitudinally as a suture nearly to base of ligula; wing pads (Figure 35 ), with one exception (Figure 33), present in medium to large size nymphs; hind wing pad with anal lobe or area extending far beyond middle of wing, about one-lialf as long as wide; last abdominal segment (Figure 33) with a conical projection in the male; legs (Figure 27) with numerous short setae and long slencler ones; venation of fore wing pad, where distin- 
guishable, without numerous cross-veins between medio-ciabital longl-

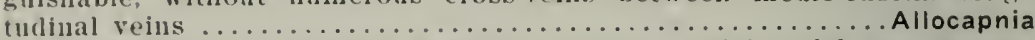
Lateral margins of abiominal segments almost straight, abdomen appear. ing cylindrical in shape: glossa of labinm (Figure 16) divided ty an in. cision which extends as a suture less than one-half length of ligula; wing pads always present in medium to large nymphs; hind wing pad with anal lobe or area not extending much beyond middle of wing. about tluee tines as long as wide; last abdominal sngment without conical projection; legs (Figure 2S) with only a few sl:orc setan or long slender ones; venation of fore wing pad, where dist.1.guishal.e. with mumerous cross-veins between medio-cubital longitudinal vein . . . . . . . . Leuctra
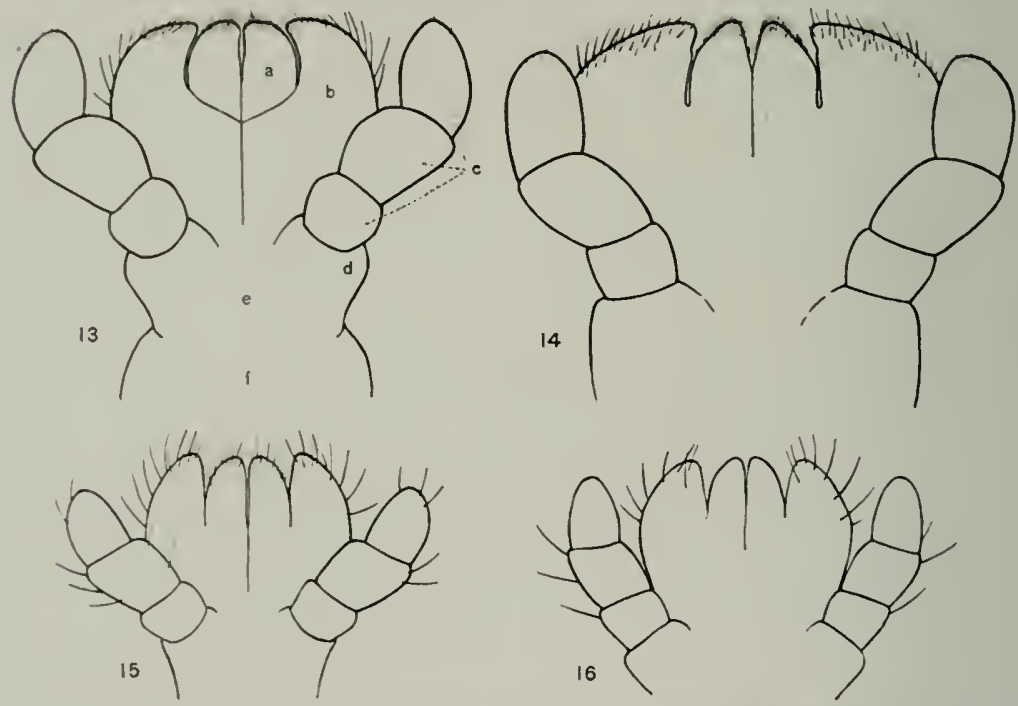

Figs. 13-11;. Labia of nympha! males: 13 , Taeniopleryx nivalis (Fitch); 14. strophopferyx fusciata (Burmeister); 15, Allocapnia vivipara (Claassen) ; 16, Lcuctra clacisseni Frison. a. glossa; b. paraglossa ; c. labial palpus; $(l$, palpiger; $e$, mentum; $f$, submentum.

\section{Keys to the Species, with Descriptions of New Species and Nymphs}

\section{TAENIOPTERYX PICTET}

Histoire Naturelle géncirale et particulière der Insectes Neuroptères.

Première Monographie : Famille des Perlides, 1841-1842, p. 345.

Genotype 'Tuniopteryx ncluulosu by original designation.

The adult males of the Illinois species of this genus have been previonsly lieved, along with other species, by Needham and Claassen (1!2:5), but the females have not received a similar treatment. The capture of mating pairs of both Illinois species belonging to this genus has insured the correct association of the two sexes and enabled the formation of keys distingnishing both sexes. Likewise. the rearing of adults from full-grown nymphs has establisherl beyond dould the correct association of the nymplis with their adults and their sexual differences. 


\section{ADULTS}

Male with a globular appendage on ninth abdominal sternite (subgenital plate); female with portion of eightl abdominal sternite (Figure 76) anteriol to genital opening darkly chitinized................ nivalis (Fitch)

Male without a globular appendage on ninth abdominal sternite; female with portion of eighth abdominal sternite (Figure 77) anterior to genital opening not darkly chitinized, at most with anterior border of genital opening dark colored, contrasting with membranous area..... parvula Banks

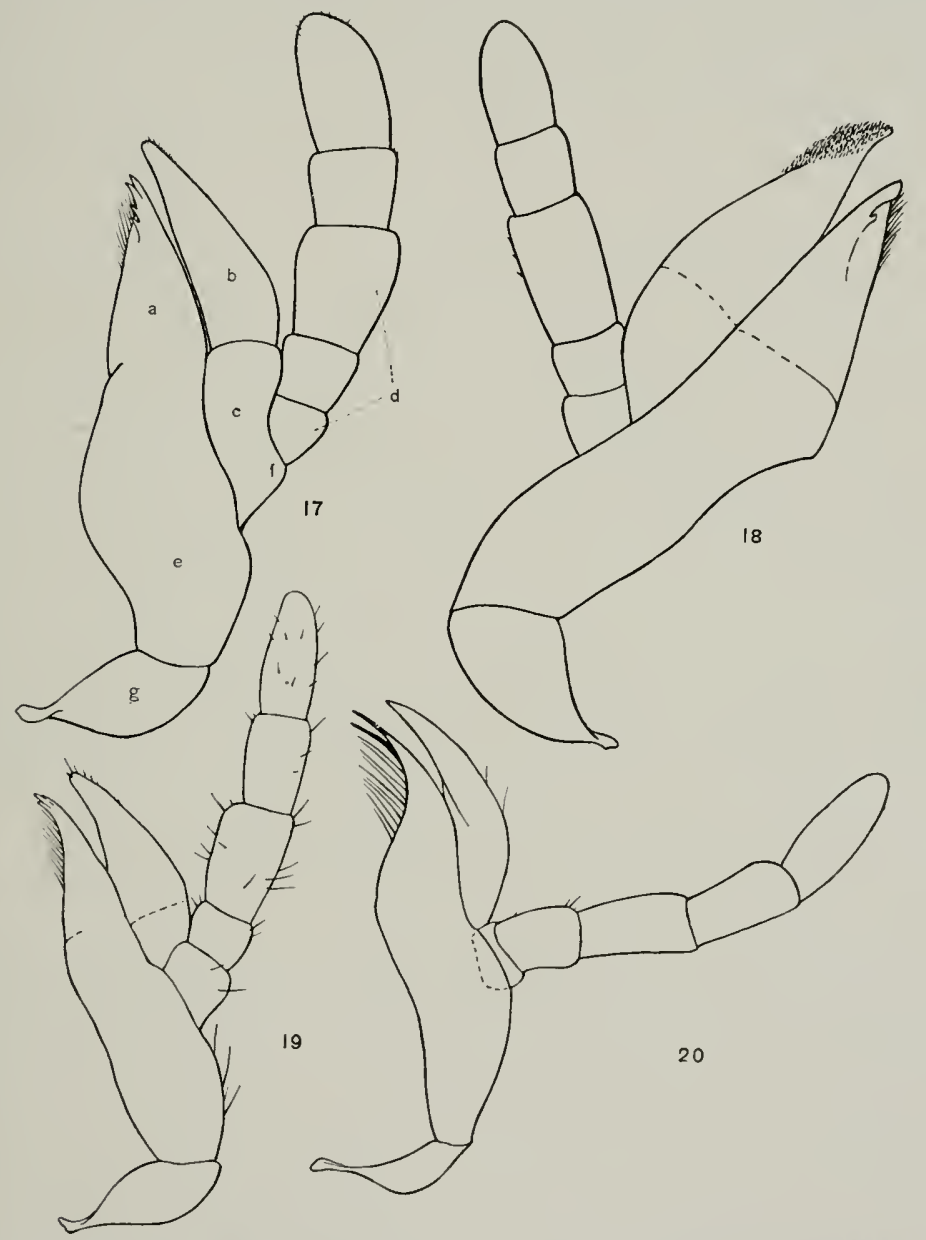

Figs. 17-20. Maxillae of nymphal males: 17, Taeniopteryx nivalis (Fitch); 18, strophopteryx fasciata (Burmeister); 19. Allocapnia vivipara (Claassen) ; 20 , Leuctra claasseni Frison. $a$. lacinia; $b$, galea; $c$, subgalea; $d$, maxillary palpus; $e$. stipes; $f$, palpifer; $g$. cardo. 


\section{NYMPHS}

Males and females with a conspicuous white mid-dorsal stripe (Figures 32 and 59) extending from head to end of abdomen; apex of abdomen seen from the side in the male (Figure 62) with supra-anal lobe protruding mucl above apical segment, not so in female; mature nymphal male with outline of globular appendage visible near middle of ninth ster.

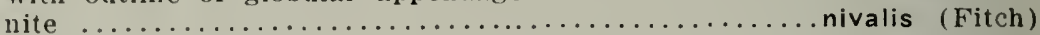

Males and females without a conspicuous white mid-dorsal stripe extending from head to end of abdomen; apex of abdomen seen from the side in the male with supra-anal lobe protruding much above apical segment, not so in female; mature nymphal male without outline of appendage visible near middle of ninth sternite.............. parvula Banks
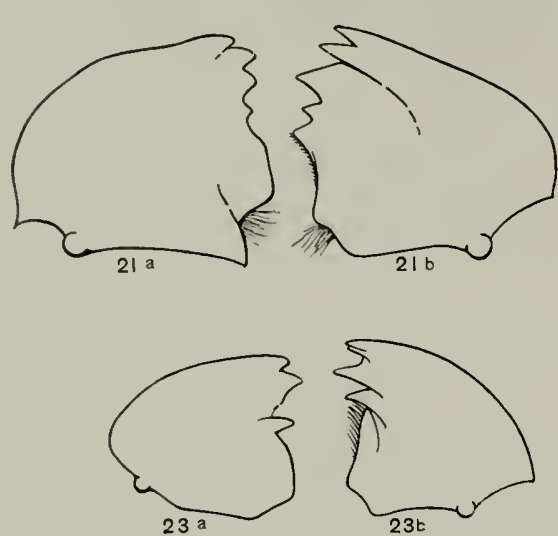

Figs, 21-24. Mandibles of nymphal males (ventral view): 21, Taeniopteryx nivalis (Fitch); 22, Strophoptcryx fasciata (Burmeister); 23, Allocapnia vivipara (Claassen); 24, Leuctra classeni Frison. a, right mandible; $b$, left mandible.

\section{TAENIOPTERYX NIVALIS (FITCH)}

Amer. Journ. Agr. Sci., Vol. V, May, 1847, p. 279, ô ․

This species, generally distributed throughout the eastern states from Maine to North Carolina and once previonsly recorded from Illinois by Needham and Claassen (1925), is one of two of the most abundant species of winter stoneflies in Illinois. Of the two most albundlant species it is the largest and therefore the most conspicuons and most frequently secn member of our winter fauna.

The male and female have been previonsly well characterized by Needham and Claassen (1925). In addlition to their cliagnosis of this species, it should be noted that the adult females almost invariably have the area anterior to the genital opening on the ninth abdominal sternite (Figure $i(i)$ very heavily and darkly chitinized. This sometimes makes it appear as though the genital opening was at the very hind margin of the ninth sternite when it is in reality merely in the posterior more membranons or light-colored portion. 
The study of thousands of specimens of this species has shown that there exists considerable variation in shape of the hind femora (Figures (it and 6.5 ) of the male. This was particularly evident in specinens from the Oakwood region, where some males of nizalis were found which showed a small tooth-like projection very strongly developed. In one case. even, a male was found with a pronounced tooth upon the tibia instead of mpon the femur-an indication of the instability of this character. In the Oakwood region about one adult male out of twenty showed a tendency for the hind femora to be toothed. As one might expect from what has just been stated, male nymphs were also found in the Oakwood region which showed a rudimentary development of a tooth-like projection on the hind femora.

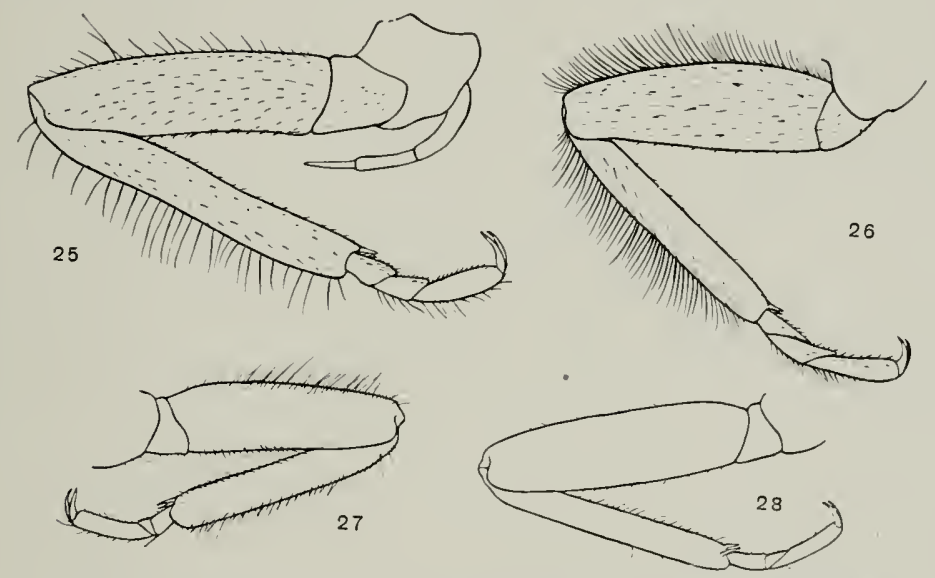

Figs. 25-28. Hind legs of nymphal males: 25, Tacniopteryx nivalis (Fitch); 26, strophopteryx fasciata (Burmeistel); 27, Allocapnia vivipara (Claassen); 2S, Lenctra claasseni Frison.

The presence of this tooth-like projection on adults positively identifiable as mialis casts some suspicion on the specific distinctiveness of $T$. maura Pictet $(18+2)$ and $T$. miralis (Fitch, $18 t_{i}$ ). T. mamra is at present scparated only in the male sex from nizalis on the basis of its tooth-like projection on the hind femora and its absence in $T$. nizalis. That this is not a positive character for differentiating maura is shown by its presence and variability on numerous males of the form now called nizalis. Through the kindness of Professor Claassen, specimens of mama from Phimmer's Island, Maryland, were sent to me for examination. In these specimens the tooth-like projection is more strongly developed than on any specinens of miralis found in the Oakwood region, but it is essentially of the same character. Since other positive characters for the differentiation of the species of mama and miralis have not been iocated, and their range coincides, it is likely that niralis and manra are the same 
species. If this is later found to te the case, mumru Pictet must st.mel as the nance of the species here listed as miralis (Fitch), becausc the name manra has priority. Niater will still he available, however, as a varictal or subspezific name for the specimens without a tooth-like projection on the hind femora of the males. The rearing of mymphs and biological sturlies of specimens of the typical muma in states where maura is the abumclant form should lead to the final solution of the problem.

That the nymphs will be fundamentally similar to nir'alis is preclictable. because the adults of muara sent to me for study show the characteristic scar (round membranous area) on coxac where tracheal gills were attached in the nymphs. As far as I am aware, this character of atchlts belonging to this group of stoneflies has not been previously mentioned in our Anerican literature, but it is of great importance. The presence of these membranous scars on the coxae of adults belonging to Tacnioptery (scusu str.) is a reliable indicator of the presence of coxal tracheal appendages in the nymphs, and itce a'crsa. After finding these scars on the coxae of adults of nizalis, a search through the literature of my subject revealed that Lauterborn (190:3) had previously reported that the adult of ncbulosa of Europe shows "an derselben Stelle. wo sie die larve aufwies, die Tracheenkiemen ganz deutlich hervor, vielleicht etwas kleiner als bei der Larve, aber sonst in Structur etc. den larvalen Kiemen vollig gleich," and that in the older adults "sie [Tracheenkiemen] erscheinen dam an feucht conservierten Thieren als kleine weichhätutige Hëckerchen von weiszlicher Farbe, an getrockneten Exemplaren dagegen zmm mindesten als helle Flecke auf chmklerem Untergrund." Asicle from the confirmatory observation of Lestage (1920), no further mention or use of this character in the adults has been marle.

The discovery that a species of Tacnioptery.r in the nymphal stage possessed coxal tracheal appendages-a new type of tracheal appendage in apuatic insects-was apparently first reported by Klapalek (1900) and shortly thereafter in America by Needham (1901). There is no doubt that these coxal tracheal appenclages have a true respiratory function, since they are (lirectly connected with the tracheal system as Lauterborn (1!)::) hats shown and as I have determined by dissections.

Adults of this species have been found at the following localities in 11linois: Algonquin, Barstow, Carmi, Castle Rock, Chicago, Chrisman, Como, Danville, Dixon, Elizabethtown, Elmwood, Georgetown, Golconda, Grayville, Hamlet, Havana, Homer, Humboldt, Kankakee, Lawrenceville, Lexington, Louisville, Mackinaw, Mahomet, MacQuon, Marengo, Mascoutah, Muncie, Monmouth, New Athens, New Memphis, Norwood, Oakwood, Ocoya, Paris, Pekin, Peoria, Pontiac, llockford, Seymour, St. Joseph, Towanda, Union Hill, Urbana, Walnut Prairie, and White Heath. The earliest record for the appearance of an adult is January 2 at Muncie and Oakwood, and the latest record is April 21 at Havana.

The nymphs have been collected at the following localities: Danville, Elizabethtown, Grayville, Homer, Hutsonville, Muncie, New Memphis, Oakwood, Pekin, Feoria, and Rock Island. The small nymphs were first found on September 20 at Muncie and last found on April 12 at Pekin. 
Since the nymphs have not before been definitely recognized and characterized, a description of both sexes based upon full-grown specimens is given.

Nymphal Male (Figures 32 and 41).-General color dark brown, with a dorsal medial light-colored strip extending froni head to apex of abdomen; legs, mouth parts, and labrum somewhat lighter in color than body; apical two. thirds of antennae and anal cerci yellow-brown or white. General body form elongate and also robust, wing pads protruding at an angle from sides of body, rarely over $11 \mathrm{~mm}$. in length exclusive of antennae and anal cerci. Head at compound eyes as wide as prothorax, rounded behind; epicranial stem as long as epicranial arm; developing ocelli arranged in a triangle, posterior ocelli situated on epicranial arms over twice as far apart as distance from one to compound eye, anterior ocellus situated forward on the iront about one-half the distance between posterior ocelli; labrum somewhat perpendicular to plane of front. Antennae long and filiform, with nearly sixty or more segments; first segment about twice as wide as second segment and at least as long as second and third segments combined, basal segments wider than long, succeeding segments gradually becoming more elongate and with apical segments two or three times as long as wide, setae minute or lacking.

Labium (Figure 13) with glossa divided into two parts by an incision which extends longitudinally as a suture nearly to base of ligula, glossae with numerous short setae at apex and much smaller than the paraglossae; paraglossae broadly curved on outer margin, not extending beyond glossae, with some long setae near apex; palpiger evident but not appearing as segment of palpus; labial palpus three-segmented, basal segment much the shortest, second and third segments about subequal in length, second segment broader than third, the latter rounded at apex. Hypopharynx about as large as ligula, lobe. like, rounded at apex and extending little if any beyond glossae. Maxillae (Figure 17) well developed, lacinia with several claw-like teeth curved in

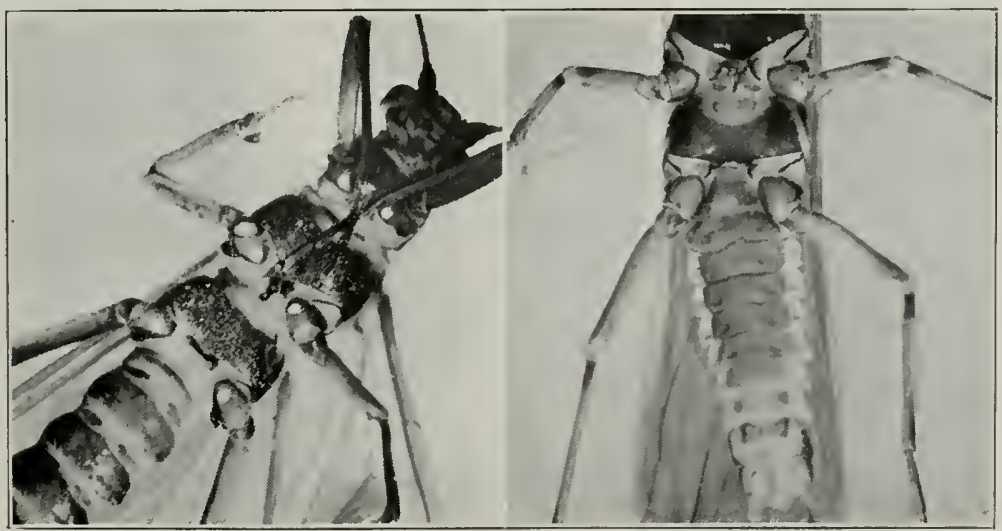

Figs. 29, 30. Ventral views of adult females: 29, Tacniopteryx nivalis (Fitch), showing scars on coxae where tracheal appendages were attached to nymph; 30, strophopteryx fasciata (Burneister) showing lack of scars on coxae (no tracheal appendages in nymph). 
wards at apex, beneath which on inner side is a row of long stiff setae; galea extending but slightly beyond lacinia, curved and tapering alnost to a point at apex, a few short setae at apex; palpifer inconspicuous; maxillary palpi five-segmented and not much longer than galea, first and second segments shortest and subequal, third and fifth segments longest and subequal, fourth seg. ment shorter than fifth and longer than second, fifth rounded at apex. Mandibles (Figure 21) heavily chitinized, with several large teeth directed in. wardly on apical half, beneath which on inner margin is a well developed mola.

Pronotum slightly broader than long, front and hind angles evenly rounded, longitudinal median pale strip one-seventh as wide as pronotum; meso- and metathorax with longitudinal median pale strip as on pronotum; ventral surfaces of thoracic segments along median area with conspicuous indications of points of invaginations of furcae; wing pads large (Figure 32 ); fore pair about

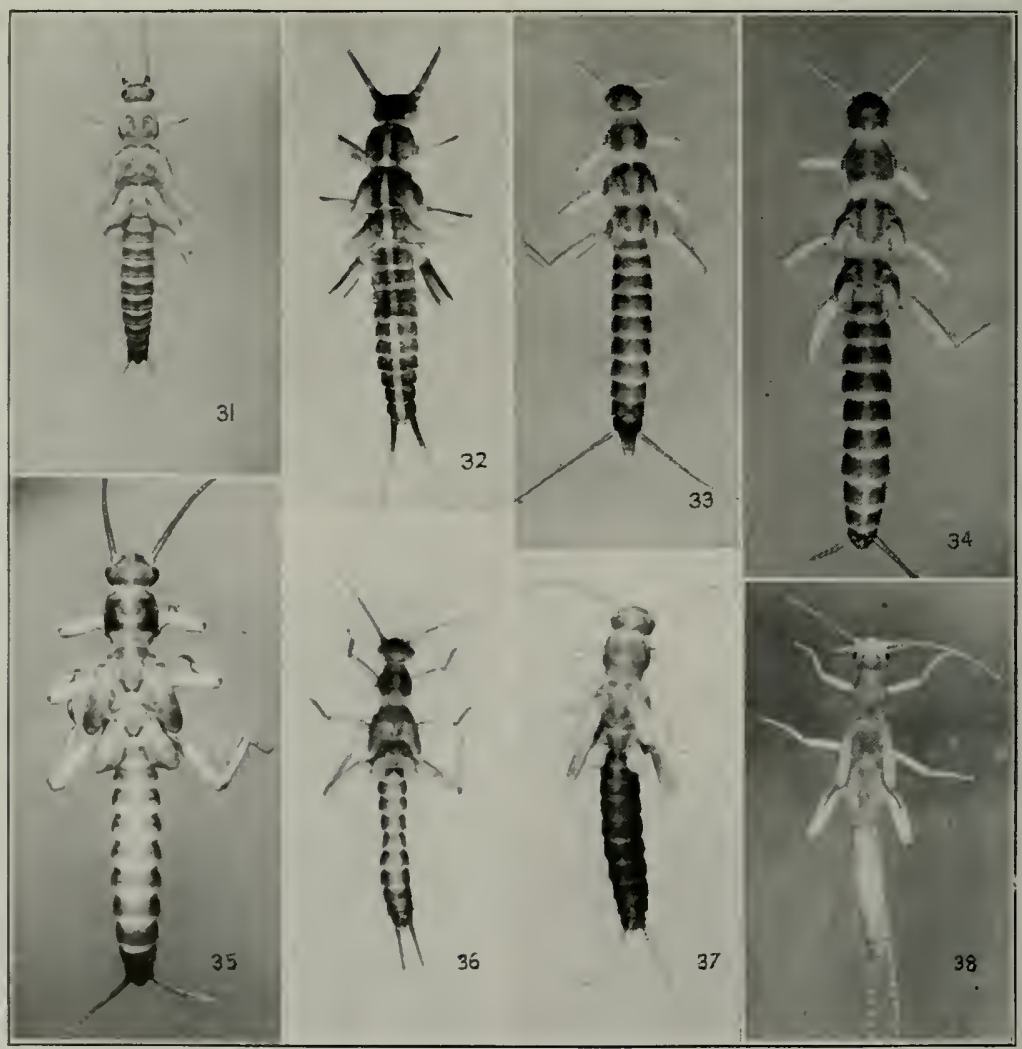

Figs. 31-38. Dorsal views of nymphs: 31, female of Strophoptcryx fasciata (Burmeister); 32, male of Taeniopteryx nivalis (Fitch); 33, male of Allocapnia vivipura (Claassen); 34 , female of A. vivipara (Claassen); 35 , female of $A$. granulata (Claassen); 36 , male of $A$. rect $a$ (Claassen); 37 , female of $A$. recta (Claassen); 38 , male of Leuctra clatsseni Frison. 
three times as long as broad, overlapping base of hind wing-pads and extending at a slight angle away from body; hind wing pads with anal lobe extending over two-thirds the length of wing, not twice as long as broad, extending at abont a forty-five degree angle from sides of body. Legs (Figure 25) long, hind legs longest and extending to or beyond apex of abdomen, fore legs shortest, tibiae somewhat longer than femora but not as broad; with numerous short, stout setae on ventral surface and some long hair-like setae on dorsal surface; tarsi three-segmented, first and second segments subequal in length, the third segment at least as long as first and second segments combined and with two large simple claws at apex; tibiae with two short spines at apex; coxae of all legs with segmented, whitish, membranous tracheal appendages (Figure 41) appearing three-segmented when extended.

Dorsum of abdomen with a narrow median longitudinal pale stripe on all the segments, llumerous short stont setae particularly on posterior margins of segments; first nine segments over twice as wide as long; tenth segment longest, not twice as wide as long, with posterior margin broadly rounded behind; supra-anal lobe (Figures 58 and 62 ) prominent and protruding much above apical segment, particularly when viewed from lateral aspect. Ninth ventral abdominal segment (Figure 60) much larger than other ventral segments, swollen and rounded behind, in some specimens with lobe-like appendage visible through integument; tenth ventral segment largely restricted to small lateral triangular areas between which are two well separated anal lobes. Anal cerci long and filiform (Figure 32), basal segments dark, middle and apical segments yellow-brown or whitish, with thirty to thirty-five segments, basal segments much broader than long, remaining segments much longer than wide, apical segments at least six times as long as wide, middle and apical segments each with about twelve long fine hair-like setae, basal segments with apical ring of short stout setae.

Nymphal frmale.-Similar in general to the male bnt averaging larger in size (11 to $13 \mathrm{~mm}$. exclusive of antennae and anal cerci). Apical dorsal abdominal segment (Figure 59) rounded behind and followed by a very small lobe-like structure which does not protrude above apical segment when viewed from the side. Ninth ventral abdominal segment (Figure 61) prolonged and rounded behind, eighth ventral segment with opening of oviduct visible through body wall.

\section{TAENIOPTERYX PARVULA BANKS}

Bull. Mus. Comp. Zool., Vol. LXII, No. 1, March, 1918, p. †. o

T. puraula is the rarest of the three large species of winter stonetlies occurring in Illinois. Thus far it has been found only along the Rock River in northwestern Illinois and the Nabash and Ohio Rivers in southeastern Ilinois. In the Oakwood region where most of the Illinois species of winter stoneflies are abundant, it does not occur. Judging by the records in literature of the occurrence of this species (this may be partly dne to the lateness in recognition of the species) it is uncommon in other parts of its range. In addition to the Illinois records given in this paper. which represent a new species record for the state, partula has been captured previously in but six states, namely: Maryland, Maine, Misconsin, Minnesota, Massachusetts, New Jersey, and the District of Columbia. 
It is evident from the characters of the adults and nymphs that parrula is very closely related to nizalis. but sufficiently distinct to deserve specific recognition. Since the present information concerning the nymphs, nsed in formulating the ley to nymphs. has been derived from a study of cast nymphal skins. from one of which the adult was reared, a detailed description of this stage is not given. The fact that the nymph lacks a mid-dorsal white stripe extending from the head to the tip of the abdonncn is evident from its lack in the cast nymphal skins. Also, the presence of the coxal tracheal appendages is evident by the presence of memliranous scars on the coxac of the adults and the evidence of them given ly the cast skins.

The allnlts have been collected in Illinois at Dixon, Elizabethtown, Grayville, Oregon, Rockford and Sterling; a nymph at Elizabethtown, and cast skins at Elizabethtown and Oregon.

\section{STROPHOPTER YX new genus}

Genotype Strophoptrryx (Scmblis) fasciata (Burmeister) by original designation and monobasic.

Renurks concerning this new genus and description of it have already been given on page :3it.

\section{STROPHOTERLX FASCIATA (BURMEISTER)}

Handbuch der Entomologie, Bd. 2, 1839, p. 875.

.lthough not previously recorded from lllinois and not as abundant as T. niz'olis, this species of winter stonefly is common in this state, particularly in the central and northern portions. According to anthentic distributional records in litt., fusciata has abont the same general distribution in North America as $T$. nizalis. Since it is the only species known to belong to this genus, the formation of a key for the identification of the species is not necessary, the generic key sufficing for this purpose. It should be mentioned, however, that the conspicuous triangular projections. on the ninth aldominal stemites of the nymphs and the adult female, and the right-angled sulogenital plate of the male, make this the most easily named species of stonefly in Illinois.

The males and females have been well characterized by Needham and (laassen $(19 \% 5)$, but since the nymph have not heretofore been recognized or characterized, clescriptions of the full-grown or nearly fullgrown nymphs of both the malc and female are presenterl.

Adults of this species have been collected at the following localities in Illinois: Algonquin, Barstow, Carmi, Castle Rock, Chrisman, Como, Danville, Denrock, Dixon, Elizabethtown. Erie, Grand Detour, Grayville, Havana, Herod, Homer, Kankakee, Lexington. Mackinaw, Maquon, Moline, Muncie, Oakwood, Ocoya, Oregon, Paris, Pontiac, Rockford, Rock Island, Seymour, Sterling, Towanda, Lnion Hill, and Utrbana.

The nymphs have thus far been collected at the following localities: Dixon. Grayville, Grand Detour, Homer, Lexington, Mackinaw, Oakwood, Oregon, Pontiac, Rockford, Rock Island, Sterling, Towanda, and White Heath. 
Nymphal Hale.-General color of ventral surface, antennae and cerci yellowbrown; first two basal antennal segments and dorsal surface brown, particularly abdominal tergites; legs mostly yellow-brown, a narrow fuscous band near apex of each femur and base of tibia. General boly form elongate and somewhat robust, wing pads protruding at an angle from sides of body, generally not over $11 \mathrm{~mm}$. in length exclusive of antemae and anal cerci. Head at compound eyes about as wide as prothorax, never wider, rounded behind; epicranial stem about as long as epicranial arm; developing ocelli arranged in a triangle, posterior ocelli situated on epicranial arms over twice as far apart as distance from cne to compound eye, anterior ocellus situated forward on the front about the length of basal antenmal segment; labrum somewhat perpendicular to plane of front. Antennae long and filiform, with about sixty segments; first segment large, abont twice as wide as second segment and about as long as three fol. lowing segments, second segment wider and longer than third segment, basal segments much broader than long, succeeding segments gradually more elongate and with apical segments about three times as long as wicle, setae at apex of antenmal segments very minute.

Labium (Figure 14) with glossa divided into two parts by an incision which extends longitudinally as a suture abont one-half the length of the ligula; glossae much smaller than paraglossae, with numerous small setae at apex; paraglossae not extending beyond glossae, nearly twice as wide as glossae, broadly curved on outer margins, with some long setae near apex; labial palpi three segmented, basal segment much the shortest, second and third about subequal in length, the latter rounded at apex. Hypopharynx lobe-like, about as large as ligula, rounded at apex and extending little if any beyond glossae. Maxillae (Figure 18) well developed; lacinia with a few teeth at apex, one of which is particularly large and blunt; galea extending slightly beyond lacinia, curved and tapering at apex, with a conspicuous sharply defined dense patch of short setae at apex; palpifer not prominent; maxillary palpi five-segmented and extending a little beyond galed, first and second segments subequal and shortest, third segment longest, fourth much shorter than fifth, the fifth slightly shorter than third and rounded at apex. Mandibles (Figure 22, heavily chitinized, with several large sharp teeth directed inwardly on apical half and with a well cleveloped mola on basal half.

Pronotum with darkly chitinized area, much broader than long, with front and hind angles rounded, contrasting maculations on disk with rather constant arrangement. Meso- and metathorax with large wing-pads; fore pair about three times as long as wide, over-lapping base of hind wing-pads and extending at a slight angle away from body; hind wing-pads with anal lobe extending abcut two-thirds the length of wing, about twice as long as broad, extending at about a forty-five degree angle from sides of body. Legs (Figure 26) long, hind legs longest and extending about to apex of abdomen, fore legs shortest, tibiae slightly longer than femora but not as broad; with numerous short, stout setae on all segments and a prominent row of long slender setae on dorsal surface of tibiae and femora; tarsi three-segmented, first segment slightly shorter than the second, the second about one-half as long as the third, the latter longer than the first and second combined and with two large simple claws at apex; tibiae with two short spines at apex; coxae without tracheal appendages. 
Dorsum of abdomen with darkly chitinized transverse area on each seg. ment strongly contrasting with lighter colored intersegmental area, setae minute but particularly prominent on posterior margin of darkly chitinized

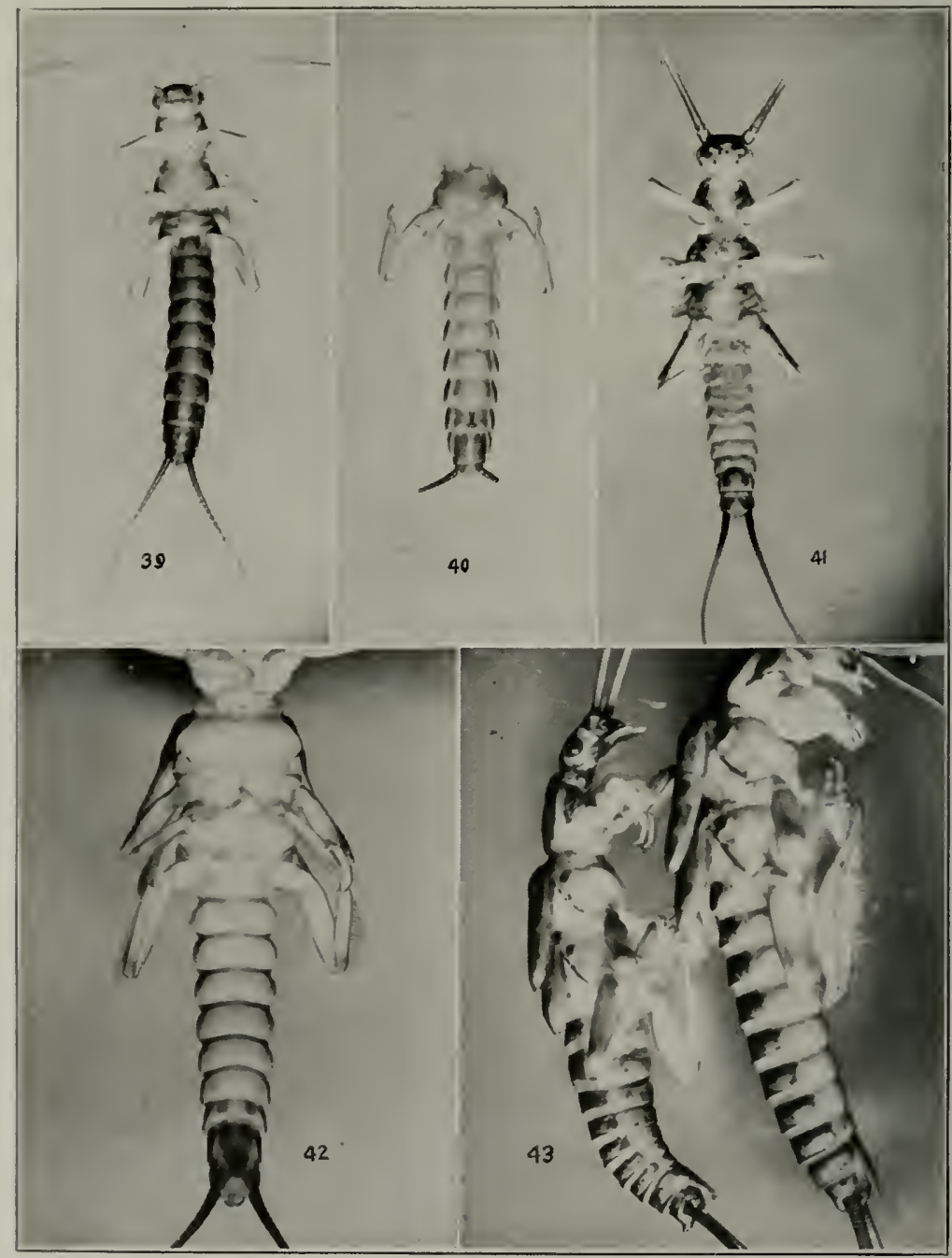

Figs. 39-43. Ventral and lateral views of nymphs: 39 , female of 4710 capnia recta (Claassen); 40 , female of Allocapnia granulata (Claassen), showing indication of structure which is characteristic of eighth abdominal segment of adult; 41 , male of Taeniopteryx nivalis (Fitch), showing coxal tracheal appendages; 42, female of Strophopteryx fasciata (Burmeister), showing subgenital process and lack of coxal tracheal appendages; 43, male (left) and female (right) of Strophopteryx fasciata (Burmeister), showing differences in size and in apical abdominal segments. 
area; first eight segments at least twice as broad as long and with lateral margins rounded, ninth segment longer than eighth, tenth segment with posterior margin somewhat $\boldsymbol{V}$-shaped; supra-anal lobe (Figure 43 ) prominent and pro-

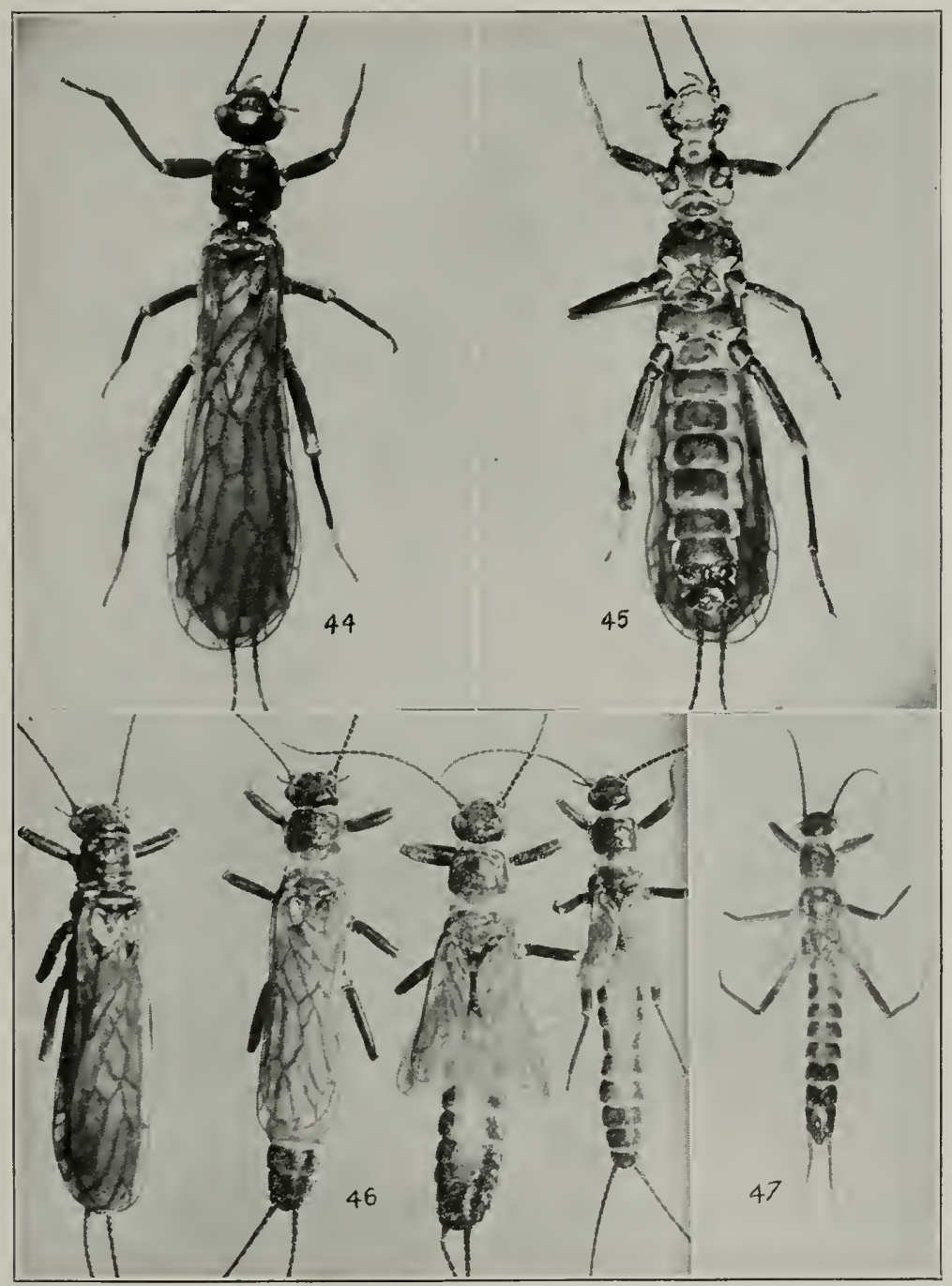

Figs. 44-47. Adults of Allocamnia: 44 and 45, dorsal and ventral views of female of $A$. gramulata (Claassen), showing long wings and venation, chitinized areas and $\mathrm{V}$-shaped posterior margin of mesosternum; 46 , dorsal view of four females of $A$. vivipara (Claassen), showing variation in length of wings and the dark chitinization of apical segments; 47 , dorsal view of male of $A$. forbesi Frison, showing short wings, longitudinal light stripe on abdomen, and dark chitinization of three apical segments. 
truding much above apical segment, particularly when viewed from lateral aspect. Ninth ventral abdominal segment without lobe-like appendage, strong. 1y prolonged into a subgenital plate which extends backward to apex of abdomen partially covering tenth ventral segment and ventral anal lobes, apex of subgenital plate blunt and as wide as base of anal cercus; tenth ventral seg. ment except lateral margins covered by ninth, anal lobes well separated and pointed at apex. Anal cerci long and filiform (Figure 31), basal segments darker than apical ones, with about fifty segments, basal segments much broader than long, middle and apical segments three or four times as long as wide; setae very minute and confined to ring about apex of segments.

Nymphat Female.-Similar in general to the male but averaging larger in size. Apical dorsal segment (Figure 43) rounded behind and followed by a small lobe-like structure which does not protrude above apical segnent when viewed from the side. Ninth ventral abdominal segment (Figure 42) strong. ly prolonged into a subgenital plate which extends backward to apex of abdomen covering middle part of tenth ventral segment, apex of subgenital plate blunt but not as wide as base of anal cercus; anal lobes well separated.

\section{ALLOCAI'NIA CLAASSEN}

Capucllı Clazssen, Can. Ent., Vol. LVI, No. 2, Feb. 1924, p. 43. (preoccupied) Allocapnir Claassen, Trans. Ent. Soc. Amer.. Vol. XXI, No. 4, Dec., 1928, p. 667. (new name)

Genotype Capnclla granulata Claassen by original designation.

According to our present knowledge this genus is endemic to North America east of the !) 5 th Meridian and only one species has been thus far collecterl west of the Mississippi River, the exception being $A$. airipara from Mlissouri. Since previons to the present study but two species of Allocupnia have been recorded from Illinois, when we now know there are at least six, it is eviclent that our knowledge of the range of these interesting little stoneflies is meagre indeed.*

The males of Allocapuiu are easy to identify because of the presence of varied and peculiar rajeed lobes or knobs on the dorsal abdominal segments. Needhan and (laksen (1925) keyed the males of species known at the time of their monograph. The females, however, present a more difficult problem, and no liey has ever been formulated for their separation. Likewise the nymphs of this genus have not been previously described or figured. This genus has its closest ally in the genus Capria. which is holarctic in distribution. The nymph of a European species, C. nigra Piclel, has been described and figured by varions investigators (Klapalek, 19)9; Ronssean, 1921: and Schoenemund, 1928) and it is (evilent that the close relationship) of the two indicated by a study of adults is sulstantiated by the structural details of the nymphs. The difficulty associated with the determination of the nymphs, and my reasons for leaving ont a key to all of them, have already been given in detail at the beginning of my discussion of taxonomic and nomenclatorial considerations.

* Siefe foringote on page 40 . 


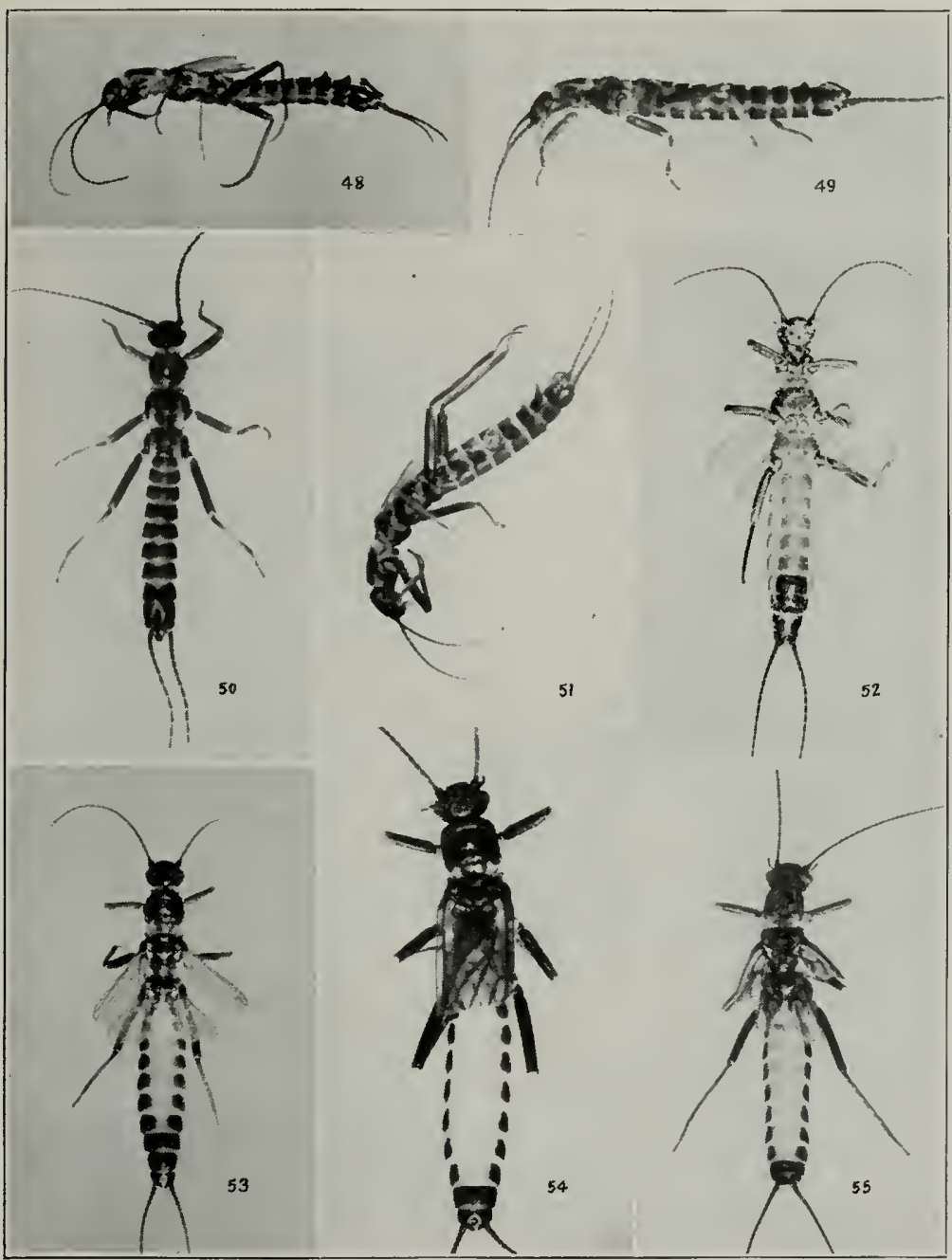

Figs. 48-55. Adults of Allocamnia: 48, lateral view of male of A. forbesi Frison, showing slort wings and knob-like protuberances on seventh and eighth abdominal segments; 49, lateral view of male of $A$. vivipara (Claassen), showing absence of wings and presence of knob-like protuberance on eighth segment only; 50, dorsal view of male of A. vivipura (Claassen), showing lack of wings; 51, lateral view of male of $A$. gramulata (Claassen), showing short wings and knob-like protuberance on eighth segment only; 52 , ventral view of female of A. vivipara (Claassen), showing lack of pale strip between seventh and eighth segments: 53, dorsal view of female of A. vivipara (Claassen), showing abbreviated wings, pale stripe on first seven segments, and dark chitinization of last three segments; 54 and 55, dorsal views of females of A. granulata (Claassen) and $A$. recta (Claassen), respectively, with wings clipped to show longitudinal pale stripe on segments one to eight and dark chitinization of last two segments. 


\section{ADULTS}

1. Eighth dorsal abdominal segment with a raised knob-like structure (Figures 47 and 67); wings either absent, abbreviated or extending nearly

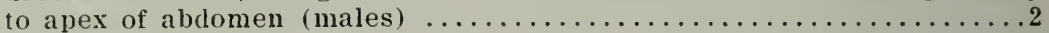
Eighth dorsal abdominal segment without a raised knob-like structure (Figures 46 and 53); wings never absent, either abbreviated or extending to or beyond apex of abdomen (females) $\ldots \ldots \ldots \ldots \ldots \ldots \ldots \ldots \ldots$

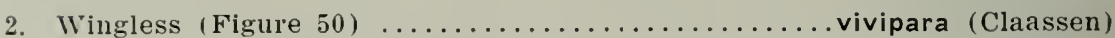

-. Wings abbreviated or long (Figures 53 and 44$) \ldots \ldots \ldots \ldots \ldots \ldots \ldots \ldots$

3. Seventh dorsal abdominal segment with raised knob-like structure about as large as that on the eighth segment (Figures 48 and 66 )...forbesi Frison Seventh dorsal abdominal segment without a raised knob-like structure as large as that on the eighth segment (Figures 49 and 51).......4

4. Wings rarely extending backwards beyond fifth dorsal abdominal segment; midl-dorsal area of aljdominal segments darkly chitinized and mid-dorsal longitudinal light stripe therefore absent; species not found in Illinois

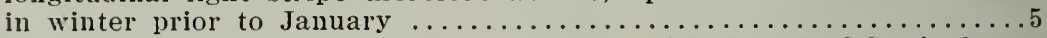

- Wings usually extenciing backwards beyond fifth dorsal abdominal seg. ment, mid-dorsal area of abdominal segments pale, contrasting with lateral margins, a mid-dorsal longitudinal light stripe therefore present; species found in lllinois in fall or winter before, rarely after, January...6

5. Knob on dorsum of eighth abdominal segment deeply divided along middorsal line into two more or less conical tubercles, situated before posterior margin of nintl dorsal segment; upper tip of supra-anal process (prong-like process recurved upward and forward over apical segments) with bulbous enlargement; apical segments of abdomen with hairs not much longer than those on middle segments......pygmaea (Burmeister)

- Knob on dorsum of eighth abdominal segment not so deeply divided along mid-dorsal line that two distinct and discomnected tubercles result, situated at apex of upward and backward directed hind margin of ninth dorsal segment (Figure 51); upper tip of supra-anal process scarcely enlarged; apical segments of abdomen with hairs much longer than those

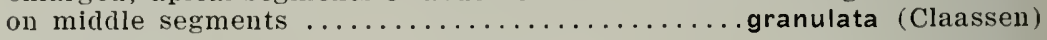

6. Knob arising at anterior margin of eighth abdominal tergite and extending backward and upward at a forty-five degree angle (Figure 67); as higl as length of seventh segment, apex of knob forming two small tubercles separated by a small cleft; supra-anal process large, nearly two times as long when extended as eighth abdominal segment........

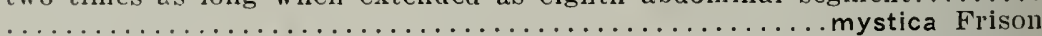

- Knob arising near middle of eighth abdominal tergite about perpendicular to horizontal plane of segment, height much less than length of seventh segment, apex of knob not cleft on top and forming a single small more or less round plateau-like area highest at anterior margin; supra-anal process small, scarcely longer when extended than eighth abdominal

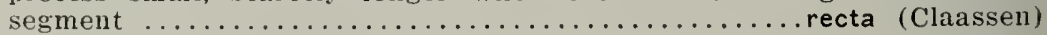

7. Last three dorsal apical segments (S, 9, and 10) of abdomen entirely and darkly chitinized (Figure 53 ), a wide longitudinal pale membranous stripe extending on dorsum of abdomen from base to hind margin of seventh

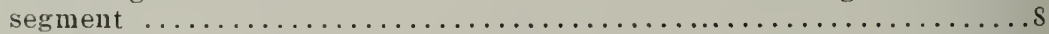
Last two dorsal apical segments only $(9$ and 10$)$ of abdomen entirely and darkly chitinized (Figure 54), a wide longitudinal pale membranous stripe extending on dorsum of abdomen from base to hind margin of eighth

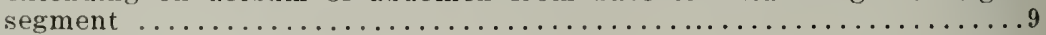


S. Posterior transverse margin of eighth ventral abdominal segment with a small rounded lobe-like projection at its middle (Figure 73); narrow trausverse pale membranous strip visible between darkly chitinized areas of seventh and eighth ventral abdominal segments in extended

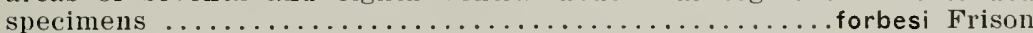

- Posterior transverse margin of eighth ventral abdominal segment straight, without a projection at its middle (Figure 74 ); (larkly chitinized areas of seventh and eighth ventral abdominal segments fused near middle, without a pale membranous strip between them (Figure 52) .........

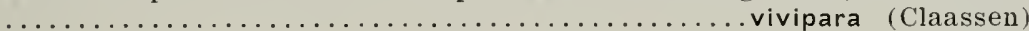

9. Darkly chitinized areas of seventh and eighth ventral abdominal segments fused near middle (Figure 75), without a pale membranous transverse

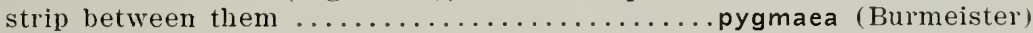

- A narrow, transverse, pale, membranous strip visible between darkly chitinized areas of seventh and eighth ventral abdominal segments in

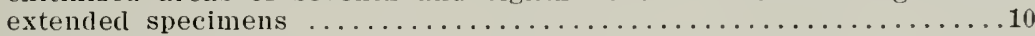

10. Posterior transverse margin of eighth ventral abclominal segment almost straight (Figure 70 ), at most with a small outward bulge at middle of

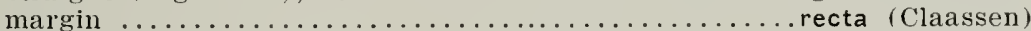

- Posterior transverse margin of eighth ventral abclominal segment with a conspicuous, but very short, sunken projection a little less than onethird as wide as darkly chitinized area of same segment...........11

11. Antennae stout, moniliform, basal and middle segments much broader than segments of maxillary palpi; eighth sternite with posterio-median process deeply inset and sharply delineated (Figure 71 ); wings sometimes very dark; larger species (body $7-9 \mathrm{~mm}$.$) ; not found in Illinois in winter$

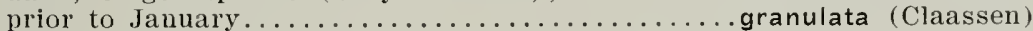
Antennae slender, filiform. basal and middle segments not much broader than segments of maxillary paIpi; eighth sternite with posterio-merian process not so deeply inset and sharply delineated (Figure 72); wings usually hyaline with veins dark; smaller species (body $6-5 \mathrm{~mm}$.); species reaching maximum abundance in lllinois in fall or winter prior to

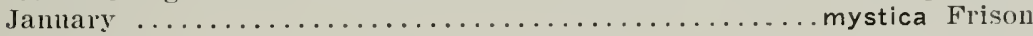

\section{NYMPHS}

1. Nymphs with a conspicuous rorsal lobe-like protuberence (Figure 33) at

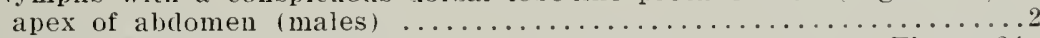

- Nymplis without a conspicuous dorsal lobe-like protuberence (Figure 34 ) at apex of abdomen, apical margin broadly rounded behind..........

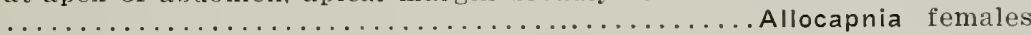

2. Nymphs (Figme 36) with wing pads (winged adults) ............. Nymphs (Figure 33 ) without conspicuous wing pads (wingless adults)

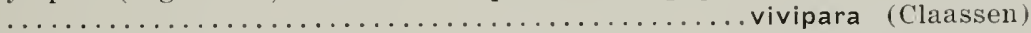

3. Fore wing pad overlapping base of hind wing pad in large nymphs....4 Fore wing pad not overlapping base of hind wing pad in large nymphs

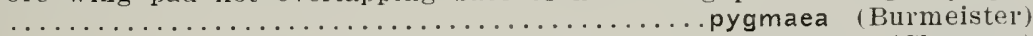
granulata (Claassen) probably forbesi Frison

4. Dorsal lobe-like protuberence at apex of abdomen nearly twice as long from base of anal cerci to apex as length of ninth dorsal abdominal segment

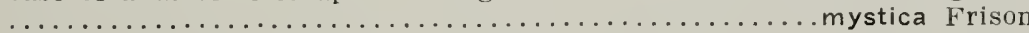

Dorsal lobe-like protuberence at apex of abdomen scarcely longer from base of anal cerci to apex than length of ninth dorsal abdominal segment

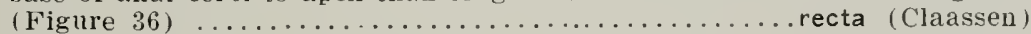




\section{ALLOCAPNIA VIVIPARA (CLAASSEX)}

(an. Ent., Vol. ldVI, No. 2, Feb., 1924, p. 46, $\delta$ ᄋ.

The arlult male of this species (Figure jo) has been (puite fully describerl hy Necolham and (latssen $(1925)$. It is the most easily identified member of the aenus because of its lack of well developed wings. N1thomgh the female (Figure $5: 3$ ) has also been described by the same atuthors, a fer additional characters have been found which should he noted. ( ) n the dorsum of the abelomen of the female (Figure 46 ) a lomgitudinal pale membranous stripe extends to the hind margin of the seventh segrnent, the eighth, ninth, and tenth segments being entirely and darkly chitinized. In acklition the posterior margin of the eighth ventral abdeminal segment (Figure $i t$ ) is straight, without a projection at its midelle, and the seventh and eighth ventral abdominal segments are fused near the middle and without a pale membranous transverse strip) between them (Figures 5:) and it).

In the original clescription, the females are described as having very short wings, and this is true for certain specimens, but in others the wings are long or of intermediate lengths between the two extremes (Figure 16 ). The distribution of the females with various wing lengths is most interesting. In southern Illinois the long-winged or macropterous females are the dominant form, but a few specimens have wings of intermediate length. In central Illinois all forms are found, but specimens with wings of intermediate length are most commonly represented in our collections. In northern Illinois all our records are for the short-winged or brachypterous forms with the exception of one female with wings of intermediate length from Ft. Sheridan. Although this distribution suggests that the brachypterous females are the product of more northern latitules, other factors such as type of stream and associated factors may be the cause. For instance, in the small stream at Oakwood (Stations II, III. IV) only the brachypterous females have been found, whereas about forty miles west in another small stream Howing into the Sangamon River near Mahomet, none of the females collected have been brachypterous, a few have been macropterous, and the majority of them have had wings of intermerliate lengih.

Although the male of this species maty be spolien of as wingless, most specimens show stubs of rudimentary wings, and in a few specimens that I have examined these wing rucliments have been very prominent. This species varies, also, in size; those in the northern and central portions of Illinois average much larger than those found near small streams in southern Illinois.

This species has previously been recorded from lllinois (the type locality, Lake Forest), New York, Missouri and Ohio. More than one thousand speci. mens of this species have been examined, and our collection contains specimens of the adults from the following localities in lllinois: Barstow, Bloomfield, Bloomington, Carbondale, Choat, Chrisman, Danville, Eichorn, Elizabethtown, Farmer City, Ft. Sheridan, Georgetown, Glenview, Golconda, Gossett, Grayville, Gays, Hillsboro, Harrisburg, Litchfield, Shelbyville, Stonefort, Herod, Humboldt, Lexington, Louisville, Mahomet, Mascoutal, Mermet, Muncie, Oakwood, Ocoya, Oswego, Pana, Paris, Pcntiac, Rock 1sland, Texas City, Towanda, Urbana, Vienna, Walnut Prairie, West York, and White Heath. 
The males of medium-sized to full-grown nymphs of this species are readily identified because of the absence of conspicuous wing-pads. The large full-grown females may sometimes be recognized by their abbreviated wing-pads, but where the long-winged females are found such a character is not reliable. The presence of male nymphs of this species is a sure indication that at least some of the female nymph associated with the males are this species. In many cases, $A$. rivipara is the only species occurring in a certain stream and hence recognition of the male makes the diagnosis of the females positive to species. In other streams containing two or more species of Allocapnia, a knowledge of the seasonal succession of the species involved will aid in the recognition of the full-grown nymphs. As there is no fool-proof way of determining the female nymphs, one interested in securing them must intimately study the streams in his locality both from the standpoint of the adults as well as from the nymphs. Esoteric information obtained in this manner will certainly lead to their capture where this species occurs.

The following descriptions of male and female nymphs are based upon full-grown specimens from a sniall stream flowing into the Sanganon River near Mahomet, Illinois, - a stream in which only this species of Allocapnia is present. Numerous adults of this species have been taken at this same place and some reared from full-grown nymphs. Other nvmphs are in the Survey Collection from the following localities: Barstow, Carbondale, Danville, Ft. Sheridan, Mahomet, Marseilles, Muncie, Oakwood, Pana, Shellyville and Starved Rock.

Nymphal Male (Figure 33).-General color brown; antennae, labrum, mouth parts, legs, apex of abdomen, anal cerci and intersegmental areas whit. ish or yellowish brown and developing compound eyes dark. General body form elongate; rarely over $8 \mathrm{~mm}$. in length. Head with scattered short setae, only slightly wider than the prothorax, widest at developing compound eyes, rounded behind; epicranial stem about one-half as long as epicranial arm; developing ocelli with posterior pair situated about in middle of epicranial arms, anterior one placed well forward on the front about as far anterior to posterior ocelli as distance between them; labrum somewhat perpendicular to plane of front. Antennae long and slender, with about forty-five segments; first segment very large in proportion to the remainder, basal segments wider than long, succeeding segments gradually becoming more elongate and with apical segments several times as long as wide, a few setae on segments.

Labium (Figure 15) with glossa divided into two parts by an incision which extends longitudinally as a suture nearly to base of ligula; paraglossae and glossae of about equal width and length; palpiger not appearing as basal segment of palpus; labial palpus tiree segmented, basal segment shortest, second segment broadest and longest of segments, third segment slightly shorter than second and broadly rounded at apex. Hypopharynx about as large as ligula, lobe-like, rounded at apex and extending but little if any beyond glossae. Maxillae (Figure 19) well developed; lacinia with several sharp teeth curved inwards at apex, beneath which on inner side is a row of long stiff setae; galea extending about as far as lacinia, curved and tapering to a point at apex; palpifer indistinct; maxillary palpi five segmented and at least twice 
as long as labial palpi, first and second segnents shortest, third and fifth segments about subequal in length, fourth much longer than second but shorter than third; fifth rounded at apex. Mandibles (Figure 23) heavily chitinized, with several teeth directed inwardly near apex, beneath which on inner mar gin is a well developed mola with smooth surface.

Pronotum with darkly chitinized area broader than long, with front angles and hind angles slightly rounded. Meso- and metanotum with conspicuous wing-pads absent, merely small rudiments present. Legs short, hind legs -not extending to apex of abdomen, prothoracic legs shortest and metathoracic legs longest, femur and tibia about subequal in length, femur much broader than tibia; tarsi three segmented, second segment very small and easily confused with the first, third segment at least twice as long as first and second combined and with two simple claws at apex; tibia at apex on lower side with two very small spines which are about one-half as long as first tarsal segment; with numerous stout setae and long hair-like ones particularly on femora.

Abdomen with lateral margins of segments somewhat rounded, segments widest near posterior margin and narrower towards base, much broader than long; tenth dorsal segnient with a conspicuous lobe-like protuberence at apex, longer than ninth dorsal segment; ninth ventral segment slightly prolonged behind, tenth ventral segment forming lateral triangular areas between which is an anal area extending backward between anal cerci for a short distance. Anal cerci present, long, filiform, with about twenty-eight segments, basal segments wider than long, middle and particularly apical segments much longer than wide, a few setae on each segment near apex.

Nymphal Female (Figure 34).-Similar in most details to the nymplaal male, except somewhat larger. Differs as follows: wing pads well developed, of varying length, hind wing pads never extending beyond second segment of abdomen; abdomen more tapering towards apex, without a conspicuous dorsal lobe-like protuberance at apex, broadly rounded behind, ventral anal area between anal cerci bifid at apex. Posterior transverse margin of eighth ventral abdominal segment straight, never with indication of median projection (Figure 74). In some specimens the lack of a pale membranous strip between the seventh and eighth ventral abdominal segments near middle may be seen through the integument.

\section{ALLOCAPNIA GRANULATA (ClaAsSEN)}

Can. Ent., Vol. LVI, No. 2, Feb., 1924, p. 44, 우 오.

This species has been quite fully described in the male sex by Needham and Claassen (1925), but some additional and important characteristics of the female (Figures $44,45,54$ ) should be brought to general notice. The customary longitudinal pale membranous band of the adult females of this genus extends from the base to the hind margin of the eighth segment; the ninth and tenth apical clorsal abdominal segments only being entirely and darkly chitinized. Furthermore, the posterior margin of the eighth ventral abdominal segment (Figure 81 ) has a conspicuous, but very short, sunken lobe-like projection a little less than one-third as wide as the darkly chitinized area of the same segment and the seventh 
ventral abdominal segment is distinctly separated from the eighth by a transverse pale membranous band.

This species has been once before recorded from lllinois (Coles Co.) by Needham and Claassen (1925), as well as from New York, Maryland, and the District of Columbia. Over nine hundred specimens have been studied and we have the following locality records for the adults of this species: Chrisman, Danville, Elizabethtown, Georgetown, Grand Detour (Castle Rock), Mahomet, Muncie, Oakwood, Oregon, Oswego, Paris, Pontiac, Rock Island, Towanda, Unnion Hill, Urbana, White Heath; showing that it is distributed here and there throughout the state, but particularly in the central and northern portions. Nymphs known to be this species are in our collection from the region of Oak. wood.

Although most of the female nymphs of this species cannot be separated in a key from nymphs of other species of this genus, and the males are readily confused with two other species, it is possible to name many of those collected because of esoteric information. There are several facts in the biology of this species which will aid the close student of the group in determining nymph of this species. As stated elsewhere, grunulata in Illinois is confined to large streans and rivers which do not reach a small pool stage in summer, whereas the reverse is true of the species mystica, recta, forbesi, and pyomaca.

Fortunately, too, the only species likely to be found associated with granulata is rizipara, a species easily recognized in the male sex. A knowledge of the distribution of the species in this state is also useful, since granulata is uncommon in southern Illinois. Furthermore, the seasonal adjustment of this species is such that the full-grown nymphs are most apt to be found when the nymphs of recta, mystica, and forbesi have disappeared. To avoid repetition, a detailed description of the nymphs is omitted, and only points of difference noted between nymphs linown to be this species and those of rizipara are given.

Nymphal Hale.-Similar in general form, color and structure to A. vivipara as described in this paper. Differs as follows: conspicuous wing pads present, the fore wing pads not overlapping the base of the hind wing pads.

Nymphal Female (Figure 35).--Differs from male in that conspicuous dorsale lobe-like protuberance at apex of abdomen is lacking and the apical mar gin is broadly rounted. In some specimens (Figure 40) the eighth ventral abdominal segment clearly shows in outline the sunken projection on posterior margin so characteristic of the adult female.

\title{
ALLOCAPNIA RECTA (CLAASSEN)
}

\author{
Can. Ent., Vol. LVI, No. 2, Feb., 1924, p. 44, 우
}

In Illinois, this species shares with forbesi the distinction of being onr rarest members of the genus, having been found only in three small brooks in the Oakwood region (Butler's Pranch, a small tributary of the Middle Fork, and at Stations II to IV). It has been recorded previously only from New York and Massachusetts. 
Sirecincms from lllinois agree very well with the description of the male and female as given hy . Teedham and Classen (19:5). but a few. additional characters of the female should be described. The wide, longiturlinal, pale, menubanous stripe on the dorsum of the abdomen in the female extends to the hind margin of the eighth segment, the last two apical abdominal segments only being entirely and darkly clitinized (Figure .j.). In addition, there is visible in extended specimens a narrow, pale. transierse, nembranons strip between the darlily chitinized areas of the seventh and eighth rentral abdominal segments. Although the posterior transverse margin of the eighth ventral abdominal segment (Figure $a(0)$ is essentially straight, there is a slight tendency in some specimens towards the development of an small ontward bulge at the middle of the margiil.

Idults and nymphs from Illinois are represented in our collection by about nine hundred specimens from the Oakwood region (Stations II to IV).

The male nymph is clistinguishable from other Allocapnia males found in this state, lut the female presents no reliable cluaracters for its ready identification. The fact that so far as known the nymphs of this species are found only in very small brooks, which reach a small pool stage in late summer or early fall, is helpful in naming the females. Furthermore. the early development of the full-grown mymphs, and the apparent absence of the species in small brooks in southern Illinois where it might be confused with mystica, pygmaca, or forbcsi, are additional helpful hints. Characters of the full-grown nwmph are as follows:

Nymphal Male (Figure 36).-Similar in general form, color and structure to A. vivipara, but smaller, rarely over $6 \mathrm{~mm}$. in length. Differs as follows: conspicuous wing pads present, the fore wing pad overlapping the base of the hind wing pad; dorsal lobe-like protuberance at apex of abdomen scarcely longer from base of anal cerci to apex than length of ninth abdominal segment.

Nymphal Female (Figure 37).-Differs from male in being slightly larger, in lacking dorsal lobe-like protuberance at apex of abdomen, and in having apical margin rounded. Posterior transverse margin of eighth ventral abdominal segment almost straight (Figure 39), never with an indication of a pronounced projection in middle as in gramulata.

\section{ALLOCAPNIA PYGMAEA (BIRMIEISTEI)}

Handbuch der Entomologie, Bd. 2, 1839, p. S74, ô.

This species is the best known member of the genus; at least, it is recorled from more localities. Previously, it has been found in New York. Maine, New Hampshire. Massachusetts, Maryland. Virginia, and the District of Colmmbia. In Illinois it is apparently confined to the extreme southern part of the state, since no specimens have been taken north of Herod. 
The best description of the adults is given by Needham and Claassen (1925), who mention the "broad light median longitudinal band extending to hind margin of segment eight" in the female. The darkly chitinized areas of the seventh and eighth rentral abdonninal segments (Figure 75 ) are fused near the middle, there being no pale transverse membranons strip between them.

Over three hundred and fifty adults of this species from Illinois have been examined and were collecetd at the following localities: Bloomfield, Eichorn. Golconda, Herod and Vienna.

The male nymphs of this species, as indicated in key to nymphs, can be separated on the basis of reliable structural characters from other known Allocapnia nymphs, except granulata. Presence of males, however, and associateri data show that we have the nymphal females as well as males from the Big Grande Pierre River near Golconda. Illinois. The fact that pymaca has not been found in Illinois north of Harrisburg removes it from consideration when naming nymphs from streams in northern and central Inlinois. Since the species is one which belongs to the late winter fauna, the full-grown nymphs are not likely to be found in streams in late fall when mystica holds sway.

Nymphal Male.--Except for being slightly smaller, similar in general form, color and structure to A vivipart. Wing pads conspicuous, fore wing pad not overlapping base of hind wing pad.

Nymphal Female.-Differs from male in being somewhat larger and with apex of abdomen rounded instead of having a lobe-like protuberance. In some specimens the lack of a definite pale transverse membranous strip between seventh and eighth ventral abdominal segments is evident.

\section{ALLOCAPNIA FORBESI new species}

This unusual species was first collected in southern Illinois in March, 19:?. Because of the fact that only four male specinens were found at that time, it was surmised that the species belonged to the true fall and early winter fatma. This stuposition was proved correct by the capture the last of November, 192r, of numerous males and females at another nearby locality.

The ontstanding difference between this new species and the remaining nembers of the genus is the presence in the male of a raised knob-like structure on the seventh dorsal abdominal segment about as large as that on the eighth. Allocupuia gramulata sometimes has the seventh dorsal abdominal segment in the male humped up a little, but never in a manner comparable to that of the eighth dorsal abdominal segment.

I take great pleasure in naming this easily recognized species of stonefly after Professor S. A. Forbes. Chief of the Natural History Surver. who has made such notable contributions to our knowledge of the fresh water faunas of the state and their interrelations. 
Male (Figure 47 and 48 ). - Length to apex of wings, $3-4 \mathrm{~mm}$.; length to apex of abdomen, 6-7 $\mathrm{mm}$. General color dark brown to blackish. Head slightly wider than prothorax, ocelli arranged in the shape of an isosceles triangle, the anterior ocellus situated well forward on the front, the hind ocelli almost three times as far apart as distance from one ocellus to compound eye. Antennae with about 30 segments, basal segment twice as wide as second, following segments gradually becoming less moniliform and more filiform towards apex, length of segments greatest in middle portion. Darkly chitinized area of pronotum quadrangular, slightly widened at base, angles somewhat rounded. surface wrinkled and with a faint median depressed longitudinal strip. Legs uniformly colored a dark brown or black; second tarsal joint small, about one-fifth as long as first tarsal segment. Wings of male abbreviated, usually extending little beyond third dorsal abdominal segment; hyaline, with veins dark and contrasting. Abdomen with dorsal apical segments beyond the sixth darker and more heavily chitinized than those preceding; first four anterior dorsal abdominal segments with a narrow median pale longitudinal membranous-like stripe and with traces of it on fifth and usually sixth segment; apical abdominai segments with conspicuous long hair-like setae. Anal cerci brown with 13-15 segments, basal segments somewhat moniliform, succeeding segments more filiform.

Seventh and eighth dorsal abdominal segments, both with a raised knoblike structure or tubercle (Figures 48 and 66); the tubercle on the seventh segment located on the posterior half of the segment, rising almost perpendicularly to the horizontal plane of segment, and forming a single cone-shaped projection as high as that on eighth segment; tubercle on the eighth segment gradually rising from near middle of segment; reaching its greatest height about perpendicular to hind margin of segment, forming on top two more or less sharp points which lie in the same transverse plane. Dorsal segments nine and ten with a median membranous depression or area for reception of the recurved supra-anal process; ninth ventral segment sharply rounded behind and apical margin produced, one and one-half times as long as width at base; subanal lobes terminating in short upcurved spine-like processes. Upper part of recurved supra-anal process forming a heavily chitinized shaft, almost as long as seventh and eighth abdominal segments, enlarged and diamond shaped at apex; lower part of process forming a sheath, broadly flaring towards apex, a tooth on each side near point of attachment with segment.

Female.-Length to apex of wings, $5.6 \mathrm{~mm}$; length to apex of abdomen, $7.8 \mathrm{~mm}$. Differs essentially from the male as follows: Wings of intermediate length, not extending much beyond sixth dorsal abdominal segment; a wide median dorsal longitudinal pale membranous strip extending from base of abdomen to hind margin of seventh segment, last three dorsal abdominal segments entirely and darkly chitinized; apical segment rounded behind; posterior transverse margin of eighth ventral abdominal segment with a small rounded lobe-like projection at its middle (Figure 73), a narrow transverse pale membranous strip visible between darkly chitinized areas of seventh and eighth ventral abdominal segments in extended specimens. 
Holotype.-Male; Tributary of North Hicks Branch, Herod, Illinois, November 20, 1928, collected by T. H. Frison. Allotype.-Female; Same data as for holotype. Paratypes all collected in Illinois by T. H. Frison and H. H. Ross as follows: one male, Clay Lick Creek, Cobden, March 7, 1928; three males, South Fork of Saline River, Stonefort, March 4, 1928; two males, North Hicks Branch, Herod, November 30, 1928; forty-three males and ten females, Tributary of North Hicks Branch, Herod, November 20, 1928.

Holotype, allotype and paratypes deposited in the collection of the Illinois State Natural History Survey.

Nymphs not definitely recognized, or if present they are indistinguishable in a series of Allocalmia nymphs from a tributary of North Hicks Branch, Herod, Illinois, collected November 20, 1928, by T. H. Frison and H. H. Ross. No doubt when found they will be similar to the nymphs of $A$, vivipara in general form, color, and structural details. Since many full-grown nymphal males of this genus show beneath outer integument indications of a raised heavily chitinized knob-like structure on ninth dorsal abdominal segment, it is prob. able some full-grown nymphal males of this species will show similar indications on eighth dorsal segment.

\section{ALLOCAPNIA MYSTICA new species}

The discovery of a new species of Allocapnia in the Oakwood region in November, 1928, came as a complete surprise in view of previous collecting in this locality. The reason that it escaped notice in 1926 and $192:$ is that it presents an excellent or extreme example of local distribution. In the fall of 1928 , as in other years, it was not found at any of the places under close observation (Stations I-IV) but in another small rocky stream (Station VII) flowing into the same river about one mile downstream and previously never examined. Here it was first found in abundance on November 1R, subsequently on November 21 , and in climinishing numbers on December 18. In southern Illinois it was found to be very abundant in Saline, Pope, and Hardin counties in the Ozarkian Uplift south of Harrisburg, but absent in somewhat similar country in Union and Jackson comnties. Ample evidence was obtained to prove that this species belongs to the late fall fama, a few specimens hanging over until the last of February.

This species is readily separated from the other species of Allocapnia by the characters given in the key. The knob on the dorsum of the eighth abdominal segment of the male is quite similar to that found in A. grammlata. but there are many important differences. The females. likewise, find their closest ally in A. gramulata. It is interesting to note that mistica is a late fall and snall strean species. whereas gramulata is a winter species most abundant during late winter and showing a preference for larger streams.

Male.-Length to apex of wings, $4-5 \mathrm{~mm}$.; length to apex of abdomen, $6-8$ mm. General color dark brown to blackish. Head wider than prothorax, ocelli arranged in the shape of an isosceles triangle, the anterior ocellus situated 
forward on the front, the hind ocelli about three times as far apart as distance from one ocellus to compound eye. Antennae slender with about 31 segments, basal segment twice as wide as second, following segments nearly all filiform and very gradually decreasing in width from base to apex, length of segments greatest in middle portion. Darkly chitinized area of pronotum quadrangular, slightly widened at base, angles somewhat rounded, surface wrinkled and with a faint median depression longitudinal strip. Legs dark, except that middle of tibiae is paler and slightly contrasts with femora; second tarsal joint small, about one-fifth as long as first tarsal segment. Wings not abbreviated as in some species, usually extending to fifth segment or beyond; hyaline, with veins contrasting. Ablomen with dorsal apical segments beyond the seventh darker and more heavily chitinized than those preceding; first six dorsal abdominal segments with a narrow median pale longitudinal membranous-like stripe; apical segments with some long hair-like setae. Anal cerci brown with about 17 segments, basal segments slightly moniliform, but succeeding segments rapidly becoming long and slender or filiform.

Eighth dorsal abdominal segment only with a raised knob-like structure or tubercle (Figure 67); the knob arising at anterior margin of eighth aibdominal tergite and extending backwards and upwards at a forty-five degree angle, as high as length of seventh tergite, apex of knob forming two small tubercles separated by a small cleft. Dorsal segments nine and ten with a median membranous depression or area for reception of the recurved supraanal process; ninth ventral segment sharply rounded behind and apex almost pointed, about one and one-half times as long as width of base; subanal lobes terminating in short upcurved spine-like processes. Upper part of recurved supra-anal process forming a heavily chitinized shaft, about as long as seventh and eighth abdominal segments, distinctly bent downwards just before terminal enlargement, this enlargement caused by perpendicular increase in size rather than increase in width across its top; lower part of process forming a sheath, broadly flaring in middle portion and apex, a tooth on each side near point of attachment with segment.
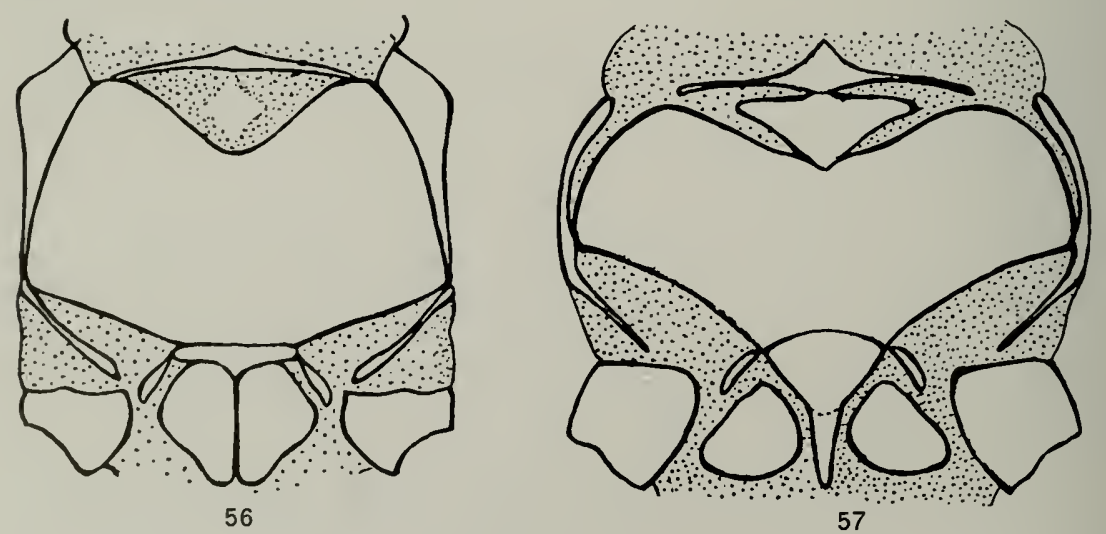

Figs. 56,57. Drawings of mesosterna of adults: 57, Allocapnia mystica Frison.

56, Capnia sp.; 
F'emale.-Length to apex of wing, $6-8 \mathrm{~mm}$.: length to apex of abdomen, 7-8 $\mathrm{mm}$. Differs essentially from the male as follows: Wings long, extending almost to or beyond apex of abdomen; a wide median dorsal longitudinal pale membranous strip extending from base of abdomen to hind margin of eighth segment, last two dorsal segments entirely and darkly chitinized; apical seg. ment rounded behind; posterior transverse margin of eighth ventral abdominal segment (Figure 72) with a conspicuous, but very short, sunken projection a little less than one-third as wide as darkly chitinized area of same segment, a narrow transverse pale membranous strip visible between darkly chitinized areas of seventh and eighth ventral abdominal segments in extended specimens.

Holotype.-Male; Small tributary to Salt Fork River, Oakwood, Illinois, November 21, 1928, mating with female allotype, collected by T. H. Frison. Allotype.-Female; same data as for holotype. Puratypes all collected in Illinois in 1928 by T. H. Frison and H. H. Ross as follows: eight males, Bankston Fork, Carrier Mills, December 1; one male and one female mating, Station VIl, Oakwood, November 1S; five males and five females mating, Station VII, Oakwood, November 21; two males and three females, Station YII, Oakwood, November 21; twenty-seven males and fifteen females, Station VII, Oakwood, November 18; three hundred fifty-four males and eighty-seven females, Station VIl, Oakwood, November 21; seventy males and twenty-five females, Blacknan Creek, Harrisburg, November 29; seventy-three males and twentyfive females, Gibbons Creek, Herol, November 29; two males and two females mating, Gibbons Creek, Herod, November 29; two hundred forty-four males and fifty-seven females, North Hicks Branch, Herod, November 30 ; seven females and forty-six males, South Hicks Branch, Herod. November 30; two males, Buck Creek, Eichorn, November 30; thirty males and three females, Three Mile Creek, Rosiclare, November 30; twenty-one males and two females, Bushy Creek, Herod, November 30 ; three males and one female, Grand Pierre River, Golconda, November 30; one male, Blackman Creek, Harrisburg, March 6; twenty-nine females, Gibbon's Creek, Herod, March 6; one male and one female, Buck Creek, Eichorn, March 6; ove female, Big Grand Pierre River, Golconda, March 7; one male and one female mating, Station VIl. Oakwood, December 18; fifty-four males and thirty one females, Station VII, Oakwood, December 18 .

Holotype, allotype and paratypes deposited in the collection of the 111inois State Natural History Survey.

Nymphs of Allocapnia mystica in our collection are from Blackman Creek, Harrisburg: North Hicks Branch and Gibbons Creek, Herod; and Oakwood, Illinois (Station VII). The male is separable from other male nymphs of the genus by characters given in the key. The fact that this species is found in streams which reach a small pool stage in late sumner or early fall and that it is a member of the late fall fauna are both aids in the recognition of the nymphs of this species. I have never found this species in association with recta; but if this does happen, as seems probalble, the females could not be separated except perhaps upon the basis of a difference in size - a most unsatisfactory character. The following descriptions are based upon full-grown nymphs: 
Nymphal Male.-Similar in general form, color, and structure to A. vivipara. Wing pads conspicuous, fore wing pad overlapping base of hind wing pad. Dorsal lobe-like protuberance at apex of abdomen nearly twice as long from base of anal cerci to apex as length of ninth dorsal segment.

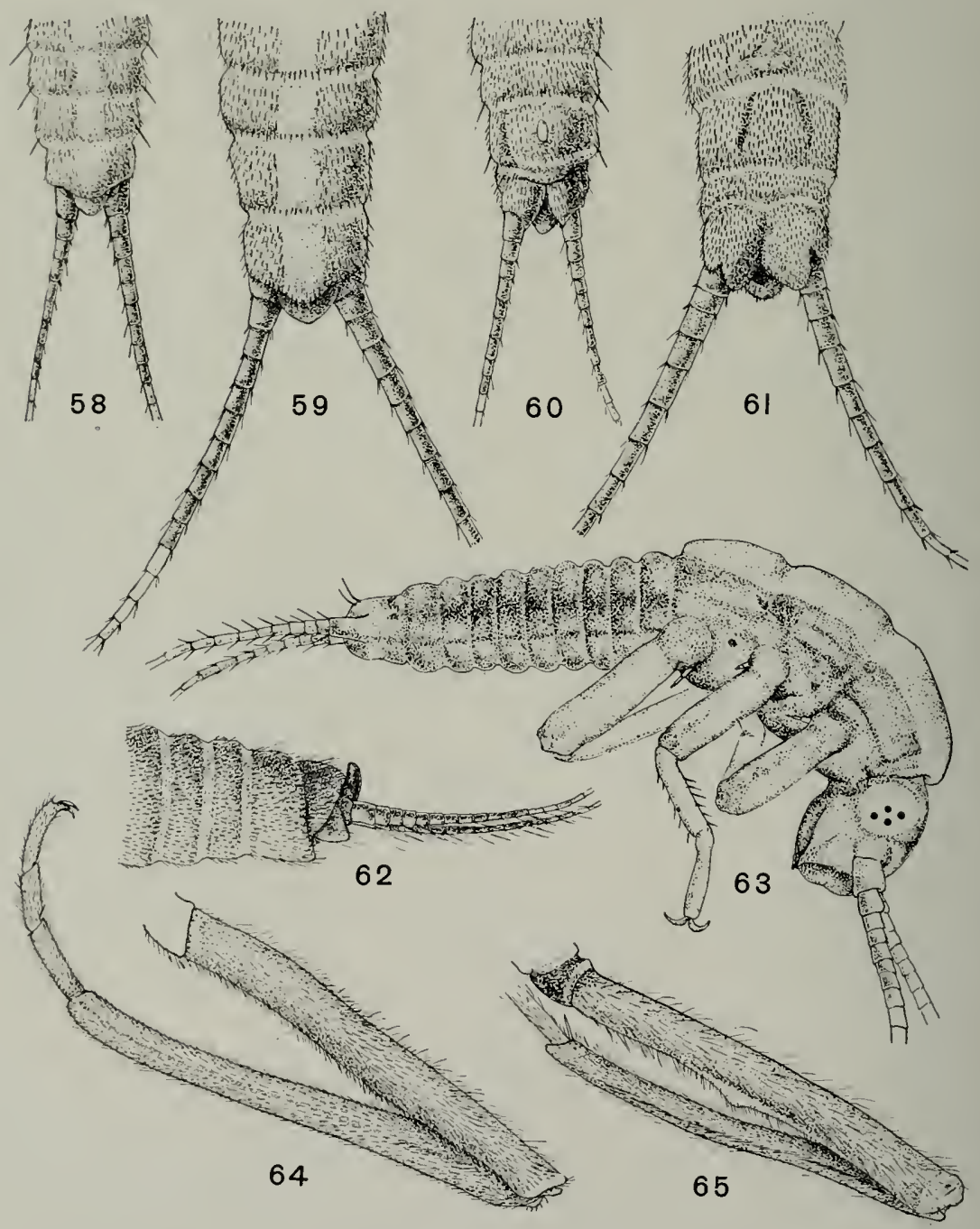

Figs. 58-65. Drawings of Tacniopteryx nivalis (Fitch): 58 and 59, dorsal views of apical segments oî nymphal male and female, respectively; 60 and 61 , ventral views of same; 62 , lateral view of apical segments of nymphal male; 63 , lateral view of very small nymph, showing incomplete development of compound eyes; 64 , hind leg of adult typical male; 65 , hind leg of adult male with indication of spur on femur. 
Nymphal Female.-Differs from male in being somewhat larger and with apex of abdomen rounded and not with a long protuberance. In some specimens an indication of the projection on the posterior margin of the eighth ventral abdominal segment may be seen through the integument.

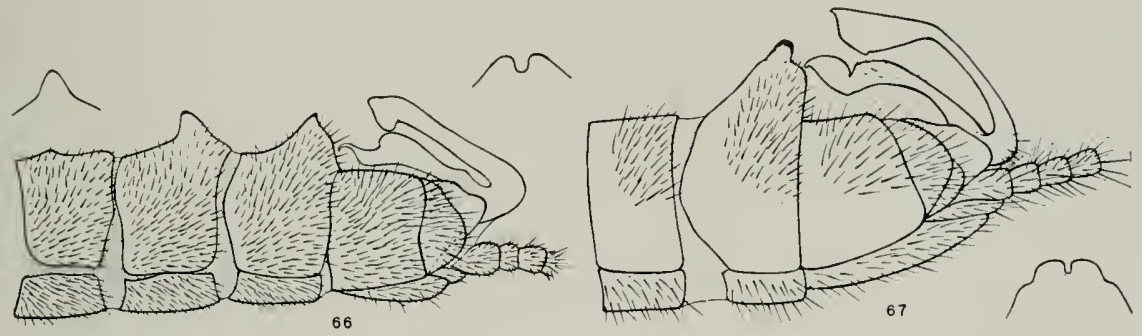

Figs. 66, 67. Lateral views of apical segments of adult males: 66, Allocapnia forbesi Frison; 67, A. mystica Frison.

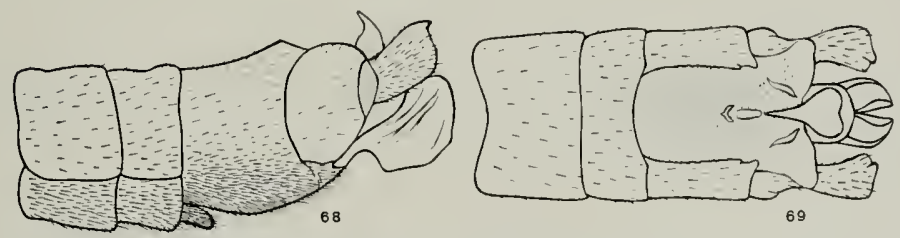

Figs. 68, 69. Lateral and dorsal views of apical segments of adult male of Leuctra clatsseni Frison.

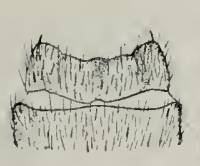

70

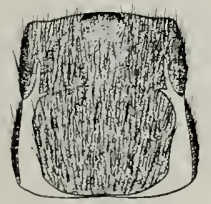

74

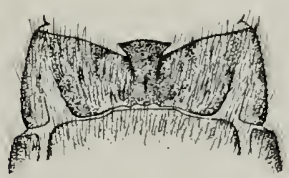

71

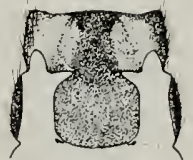

75

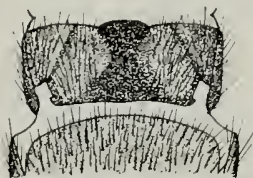

72

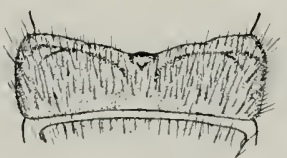

76

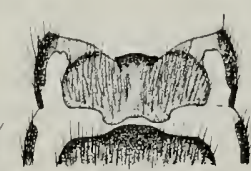

73

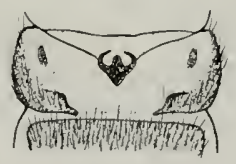

77

Figs. 70-77. Ventral views of seventh and eighth abdominal segments of adult females: 70 , A. recta (Claassen); 71, A. granulata (Claassen); 72, A. mystica Frison; 73, A. forbesi Frison; 74, A. vivipara (Claassen): 75, A. pygmaca (Burmeister); 76, Tacniopteryx nivalis (Fitch) showing genital opening; 77, T. pavula Banks, showing genital opening. 


\section{LEUCTRA STEPHENS}

Illustrations of British Entomology, Mandibulata, Vol. VI, 1835, p. 144. Genotype Leuctra geniculata Stephens of Europe-subsequent designation of Enderlein, 1909.

According to Needham and Claassen (1925) no specimens of this genus have been collected in any of the central states. The finding in Illinois of two males and nine nymphs of a new species belonging to this genus is therefore of more than usual interest. Since the typic specimens come from the higher parts of the Ozarkian Uplift in Pope county, it seems probable, from the lack of comparable regions elsewhere, that the new species has a very restricted distribution in this state.

\section{LEUCTRA CLAASSENI new species}

In the key to the North American species of Leuctra published by Needham and Claassen (1925), this new species will best rum to couplet 4. which differentiates between the species glabra Claassen and infuscata Claassen. It may be separated from glabra by the presence of a ventral lobe and from infuscata by the deeply excavated and sharply delineated area on the dorsum of the ninth abdominal segment.

It is with much pleasure that I name this species for Professor P. W. Claassen, of Cornell University, who has done so much to make known the stonefly fauna of North America.

Male.-Length to apex of wings, $8-9 \mathrm{~mm}$; expanse of wings, 14-16 mm.; length to apex of abdomen, 6-7 mm. General color yellow-brown; darker on head, and dorsum and pleurae of thorax. Head almost one and one-third times as wide as prothorax; ocelli arranged in a triangle, the anterior ocellus located about as far forward on the front as distance between the two hind ocelli, hind ocelli about three times as far apart as distance from one ocellus to compound eye, a marked pale depression between each ocellus and compound eye, hind ocelli situated about one-half length of pronotum anterior to pronotum. Antennae long and slender, with about forty segments; basal segment very large, basal segments of flagellum slightly moniliform and about as wide as long, succeeding segments more slender and filiform, those in apical half of flagellum about three times as long as wide; covered with fine setae, those at apex of segments longer and conspicuous. Pronotum about as long as wide, slightly wider at base than at anterior margin, transverse, dark, with distinct impressed anterior and posterior lines; a slightly depressed median longitudinal furrow, bisected by a slight ridge parallel with sides of furrow, about one-fifth as wide as pronotum; hind angles sharp, front angles somewhat rounded; lateral discs somewhat rugose. Legs of same general color as body; hind tibiae much longer than femora; lower part of second tarsal segment twice as long as upper part, lower part about one-fifth as long as first tarsal segment, first tarsal segment of hind leg as long as second and third combined; claws simple. Wings long, extended beyond apex of abdomen; slightly infuscate, with veins brown. Abdomen cylindrical, with the first eight segments unmodified. Ninth dorsal abdominal segment considerably modified (Figures 68 and 69); dorsum 
with a sharply defined longitudinal deeply impressed basin, open behind, rounded and closed near anterior margin of segment; lateral margins of depressed area forming together with posterior margin of segment a triangular projection on each side, a conspicuous tooth-like projection directed upward and inward along each lateral margin of depressed area in posterior half of its length and several smaller teeth anterior to large projection. Ninth ventral abdominal segment with a hairy lobe-like appendage at base in middle, wider than long, posterior margin of segment considerably produced and rounded behind. Tenth dorsal abdominal segment with a deeply excavate area but not sharply delineated. Anal cerci one-segmented, about twice as long as wide, with a small heavily and darkly chitinized rounded hump near apex on inner and upper side. Supra-anal lobe bulbous at base and wider than anal cerci, gradually tapering to a point from base to apex; viewed from the side it is claw-like. Subanal lobes labellae-like, large, with sac-like folds, broadly blade-like when viewed in lateral aspect; titillators absent.

Holotype.-Male; Bushy Fork, Herod, Illinois, March 6, 1928, collected by T. H. Frison and H. H. Ross. Paratype.-Nale; Gibbons Creek, Herod, Illinois, March 6, 1928, collected by T. H. Frison and H. H. Ross. Holotype and paratype deposited in the collection of the Illinois State Natural History Survey.

As far as I an aware the nymph of only one North American species belonging to this genus has been described (Needhan, 1!001), and the genus has been only once placed in an American key, by Dr. Claassen in a recent pamphlet by Needham and Needham (19.2i).* The nymphs of Leuctra before me, however, cannot be placed to genus in this key because the third tarsal segment is longer in all legs than the first and second segments combined. In the adult the first tarsal segment is much longer in proportion to the other tarsal segments than in the nymph-a condition that is duplicated in the case of nymphs and adults of Allocapnia. Unfortumately, the description of the nymph given by Needham (Leuctra tonuis Pictet = toncla $)$ is so brief that no comparative statements can be made between it and the one described here as new. Although the adult of this species was not reared from nymphs. I am convinced that the nymphs described below in detail are the immature forms of the species described as claassni because of much circumstantial evidence: the nymphs being collected in streams containing the inmature forms of only two related winter stonefly genera (Allocapmia and Leuctra), the capture of adults of two genera of winter stoneflies at same time and place (Allocapnia and

* In a paper by Uéno (1929) on the stoneflies of Japan, published while this article was in press, a single nymph was questionably assigned to the genus Lenctra. Since this nymph is reported to possess "neither eyes nor ocelli" I doubt that it is a true representative of this genus; for the nymph of Leuctrat figured by Rousseau (1921) has both eyes and ocelli, and so does the nymph of Leuctra claasseni.

In the same paper the genus Allocapniu $(=C a b n c l l a)$ is reported from Japan, but some features in the description of the adult indicate that it is not an Allocapnia in the strictest sense. The nympl was not described. The nympli figured under the name of Takagripopteryx nigra Okamoto is suggestive of the genus Allocapnia in some respects but differs in the shape of the fourth segment of the maxillary palpus. Uene nientions that the genus Takagripopteryx "may be a variety of the genus Capnella." 
Limctra). seasonal adjustments of nymphs and adults, and morplological points of agreenent between nymphs and adults (venation, month parts, horly iorm, etc.).

. 11 nymples collected on March 6,1928 , by T. H. Frison and H. $H$. Ross at following localities in Illinois: Two males and one female, Blackman Creek, Harrisburg, and three males and five females, Gibbon's Creek, llerod. The following descriptions are based upon full-grown nymphs:

Nymphal Male (Figure 38).-General color yellow-brown, general body form elongate; about $8 \mathrm{~mm}$. long. Head much wider than the prothorax, widest at compound eyes, rounded behind; epicranial stem about as long as one-half of wilth of prothorax; developing ocelli in same relative positions as in adult; labrum somewhat perpendicular to plane of front. Antennae long and slender, fifty or more segments in each antenna; first segment very large, basal seg. ments wider than long, succeeding segments gradually beconing more elongate and with apical segments several times as long as wide, a few setae on segments.

Labium (Figure 16) with glossa divided into two parts by an incision which extends longitudinally as a suture less than one-half the length of the ligula; paraglossae about as broad as glossae combined and not extending beyond them; palpiger distinct and almost appearing as short basal segment of palpus; labial palpus three segmented, basal segment shortest, second and third segments longer than first and of about equal length, third or terminal segment less broad than second and gradually rounded and tapering at apex. Hypopharyux about as large as ligula, lobe-like, rounded at apex and not extending beyond glossae. Nlaxillae (Figure 20 ) well developed; lacinia with two slender, sharp teeth curved inwards at apex, beneath which on inner side is a row of long stiff setae; galea extending slightly beyond lacinia, curved and tapering to a point at apex; palpifer indistinct, and appearing as basal segment of palpus, maxillary palpi five-segmented and about twice as long as labial palpi, basal or first segment very short and likely to be confused with palpifer, second segment shortest and about one-half as long as fifth, third and fourth segments subequal, fitth segment a little longer than the third. Mandibles (Figure 24) heavily chitinized, with several teeth directed inwardly near apex, beneath which on inner margin is a well developed mola with some short stiff setae.

Pronotum with clarkly chitinized area almost quadrate, with front angles slightly rounded and hind angles conspicuously rounded. Meso- and metathorax supporting wing pads which extend backwards nearly parallel with body. Fore wing pads long and narrow, overlapping basal third of hind wing pads; hind wing pads likewise long and narrow with anal lobe not extending much beyond middle of wing pad; venation of wing pad when distinguishable typical for genus, with numerous cross-veins between medio-cubital longitudinal veins. Legs (Figure 28) short, prothoracic legs shortest, metathoracic legs longest, femur and tibia of about equal length, femur much broader than tibia; tarsi three-segmented, second segment very small, third segment two or three times as long as the first and provided with two simple claws at apex; tibia at apex on lower side with two spines about one-third as long as the first tarsal segment; some short stout setae on ventral aspect of all segments. 
Abcomen appearing cylindrical, with lateral margins of segments almost straight and not noticeably tapering towards apex; first seven dorsal segments of about equal size and slightly broader than long, eighth and ninth dorsal segments about twice as broad as long, tenth dorsal segment rounded behind and from lateral aspect somewhat lobe-like and humped up at apex; ninth ventral segment with faint indication of lobe-like appendage visible through body wall, tenth ventral segment forming triangular lateral areas between which is a large anal area somewhat pointed on posterior margin and longitudinally bisected by an incision for one-half of its length. Anal cerci present, number of segments doubtful because of broken cerci, at least nineteen in one specimen; first few basal segments about as long as wide, succeeding segments rapidly becoming much longer than wide, those towards apex much broader at apex than at base and with a row of long stiff setae around each segment near apex.

Nymphal Female.-Similar in general to the male. Abdominal segments as a whole much broader than long, apical dorsal segment broadly rounded behind and without hump-like lobe at apex when viewed from lateral aspect.

\section{CAPNIA P'ICTET}

Histoire Naturelle Générale et Particulière des Insectes Neuroptères. Première Ilonographie : Famille des Perlides. 1841-1842. p. 320.

Genotype Capnia nigra Pictet of Europe-subsequent designation of Enderlein, 1909.

\section{CAPNIA sp.}

A unique female belonging to this genus was collected at Grayrille, Illinois, on March S, 1928, by T. H. Frison and H. H. Ross. Since no keys exist for the determination of the females of this genus, and males were not found to associate with the female, the Illinois representative of this genus must go mmamed for the present. Only one species-Capnia acrnalis Newport-of the nineteen known North American members of the genus has been found east of the Rocky Mountains. This is suggestive that the 1llinois specinen is this species, but it may be an undescribed one or a western form ranging eastward.

Structurally, the female agrees well with the description of the female of Capnia z'crnalis Newport as given by Needham and Claassen (1925). but since the differential or specific characters of the females of the genus have not been defined this can not be taken as conclusive proof of specific identity. It is included in this paper because its date of capture places it in our Illinois list of winter stonetlies, and in hope that mention of it will lead to interested parties discovering the male. Furthermore, the record is important because the genus Capnia has not heretofore been recorded from any state in the Mississippi basin. 


\section{BIBLIOGRAPHY}

The following list of publications includes the papers to which direct citations are made in the text. Many additional references to the literature dealing with Plecoptera are contained in some of the papers here listed.

Alibinu1. Hemian

1859. Note sur la Taenioptrryx nebulosa L. et la T. praetexta Burmeister. Ann. Ent. Soc. Belgique, Tome XXXIII, pp. 51-68, pI. I.

BANKS, NATHIN

1905. New Genera and Species of Perlidae. Psyche, Vol. XII, JuneAugust, pp. 55-57.

1907. Catalogue of the Neuropteroid Insects (except Odonata) of the United States. Amer. Ent. Soc., Philadelphia, pp. 1-53.

1918. New Neuropteroid Insects. Bull. Mus. Comp. Zool., Vol. LXII, No. 1 , pp. $3-22$, pls. $1-2$.

BCRMEISTER, $\mathrm{H}$.

1S39. Handbuch der Entomologie. Band II, Part 2, T. C. F. Enslin, Berlin. pp. $863-881$.

ClAASSEX, P. W.

1924. New Species of North American Capniidae (Plecoptera). Can. Ent., Vol. LVI, No. 2, Feb., pp. 43-4S.

1928. Additions and Corrections to the Monograph on the Plecoptera of North America. Ann. Ent. Soc. Amer., Vol. XXI, No. 4, Dec.. pp. 667-668.

Eximerieis, G.

1909. Klassification der Plecopteren, sowie Diagnosen neurer Gattungen und Arten. Zool. Anz., Band XXXIV, Nr. 13-14, June 15, pp. $385-419$.

Fitcii, A.

1S47. Winter Insects of Eastern New York. Amer. Journ. of Agr. and

KI.AP.1LEK, F. Sc., Vol. V, No. 13, May, pp. 2i4-2S4.

1900. Plekopterologické-Studie. Bulletin de l'Académie des Sciences de Bohême, IX, pp. 1-34, pl. II, figs. 28-32.

1902. Zur Kenntniss der Neuropteroiden von Ungarn, Bosnien und Herzegovina. Termeszetrajzi Füzetek, Budapest, Vol. XXV, pp. 17 S-1S0.

1909. Die Süsswasserfauna Deutschlands, Heft 8, Plecoptera, pp. 33-95, figs. $54-177$.

Koposex, J. S. W.

1917. Plecopterologische Studien, I und II, Die Plecopteren-arten Fin. lands. Acta Societatis pro Fauna et Flora Fennica, 44, No. 3 , pp. 1-18, figs. $1-5$; No. 4 , pp. 1-28, figs. 1-12.

LAITLR:ROR, R.

1903. Trakeenbiemen an den Bienen einer Perliden-Larve (Taeniopteryx nebulosa L.). Zoologischer Anzeiger, XXVI, pp. 637642 , figs. $1-2$.

LEsT.IGe, J.-A.

1920. Etudes sur la Biologie des Plécoptères. II.-La Larve de Tepheloptrryx nebulosa L. Annales de Biologie Lacustre, Tome X, pp. 231-260, figs. 1-13.

MERTEXS, $\mathrm{H}$.

1923. Biologische und Morphologische Untersuchungen an Plekopteren. Archiv für Naturgeschichte, Band 89 , Abt. A, Heft 1, pp.

Nemilas, J. G. $1-38$, figs. $1-18$.

1901. Aquatic Insects in the Adirondacks : Plecoptera. New York State Museum, Bull. 47, September, pp. 412-418, figs. 4-5. 
Nerinam, J. G., and P. W. Cliassex

1925. A Monograph of the Plecoptera or Stoneflies of America North of Mexico. Thomas Say Foundation of Entomological Society of America, Vol. II, pp. 1-397, pls. 1-50, figs. 1-29.

Neenimali. J. G., and P. R. NeEdhall

1927. A Guide to the Study of Fresh-water Biology. The American Vicw-

NeERACher, F. point Society, New York and Albany, pp. S-10, p1. 1.

1910. Die Insektenfauna des Rheins und seiner Zuflüsse bei Basel. Revue Suisse de Zoologie, Tome 18, No. 2, August, pp. 497590 , figs. $1-19$.

Newcomer, E. J.

1918. Some Stoneflies Injurious to Vegetation. Journal of Agricultural Research, Vol. XIII, No. 1, April, pp. 37-42, pls. 2-3.

Newrokt, George

1851. On the Anatomy and Affinities of Pteronarcys regalis Newm.: with a Postseript, containing Descriptions of some American Perlidae, together with Notes on their Habits. Transactions of the Linnean Society of London, Vol. XX, Part III, pl]. 447452 , pl. XXI.

PicteT, F. J.

18 11-1842. Histoire naturelle générale et particulière des Insectes Neuroptères. Première Monographie : Famille des Perlides. Genève, Kessman, pp. 1-423, col. pls. 1-53.

RECTER, E.

1904. Tidigt uppträdande af Perliden (Tacniopteryx ncbulosa L.) Medøl. Societatis pro Fauna et Flora Fennica, 30, pp. 99-100.

Rorsseic, E.

1921. Les Larves et Nymphes Aquatique des Insectes d'Europe.

SCHotexnITN, E. Lebègue, Bruxelles. Vol. I, pp. 274-320, figs. 73-88.

1925. Beiträge zur Biologie der Plecopteren-Larven mit besonderer Berücksichtigung der Atmung. Archiv für Hydrobiologie. Band XV, pp. 339-369.

1928. Die Tierwelt Mitteleuropas. Band IV, Teil 1, Lieferung 2, Plecoptera. pp. 1-18, figs. 1-63.

S.IITI, J. B.

1910. Annual Report of the New Jersey State Museum including a Report of the Insects of New Jersey. pp. 39-41, fig. 5.

Sม1тIı, L. W.

1913. The Biology of Perla immarginata Say. Ann. Ent. Soc. Amer., Vol. VI, No, 2, June, pp. 203-211, pl. XXIIl, figs. 1-2.

1917. Studies of North American Plecoptera (Pteronarcinae and Perlodini). Trans. Amer. Ent. Soc., Vol. XLIII, December 28, pp. $433-489$, pls. XXIX-XXXIV, figs. A-E.

Stephexs, J. F.

1835. Illustrations of British Entomology : Mandilulata, Vol. VI, pp. 134-145, pl. XXXI.

UÉxo, Mastzo

1929. Studies on the Stoneflies of Japan. Memoirs of the College of Science, Kyoto Imperial University, Series B, Vol. IV, No. 2, Article 5, Feb., pp. 97-155, 26 text figs., pl. xxiv.

Wu, C. F.

1923. Morphology, Anatomy and Ethology of Nemoura. Bull. Lloyd Library No. 23 , Ent. Ser. No. 3 , pp. 1-81, pls. I-XVI. 